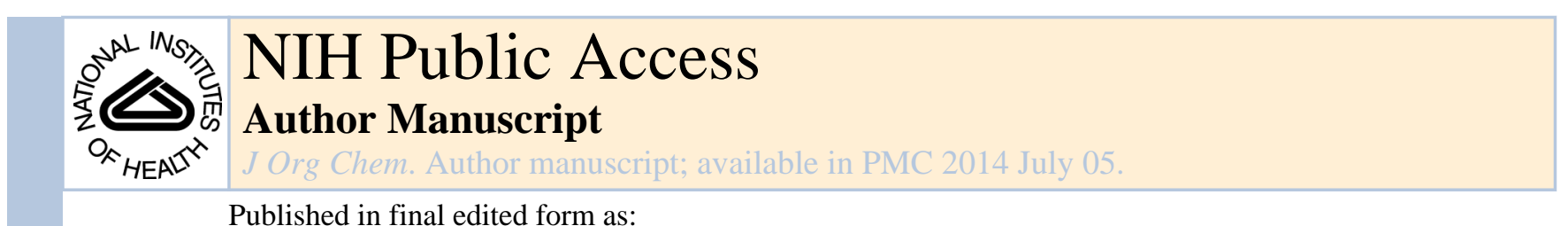

J Org Chem. 2013 July 5; 78(13): 6412-6426. doi:10.1021/jo4007893.

\title{
Stereocontrolled Syntheses of Peptide Thioesters Containing Modified Seryl Residues as Probes of Antibiotic Biosynthesis
}

\author{
Nicole M. Gaudelli and Craig A. Townsend* \\ Department of Chemistry, Johns Hopkins University, 3400 N. Charles Street, Baltimore, MD \\ 21218
}

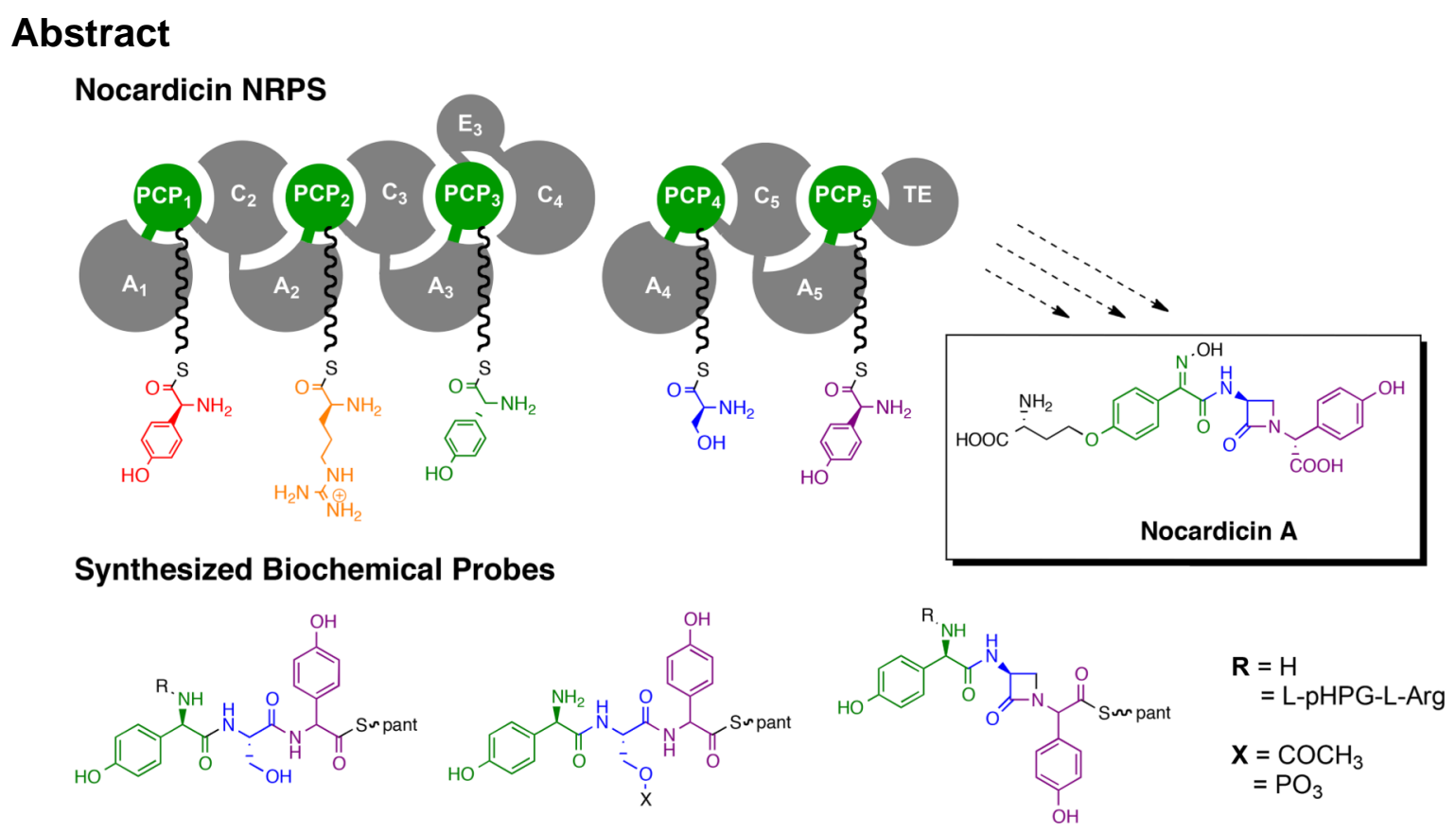

Methods have been developed to synthesize tri- and pentapeptide thioesters containing one or more $p$-(hydroxyphenyl)glycine (pHPG) residues and $\mathrm{L}_{\text {-serine, }}$ some where the latter is $O$ phosphorylated, $O$-acetylated or exists as a $\beta$-lactam. Selection of orthogonal protection strategies and development of conditions to achieve seryl $O$-phosphorylation without $\beta$-elimination and to maintain stereochemical control, especially simultaneously at exceptionally base-labile pHPG acarbons, are described. Intramolecular closure of a seryl peptide to a $\beta$-lactam-containing peptide and the syntheses of corresponding thioester analogues are also reported. Modification of classical Mitsunobu conditions are described in the synthesis of the $\beta$-lactam-containing products and, in a broadly useful observation, it was found that simple exclusion of light from the $\mathrm{P}(\mathrm{OEt})_{3}$-mediated Mitsunobu ring closure, afforded yields of $>95 \%$, presumably owing to reduced photodegradation of the azodicarboxylate used. These sensitive potential substrates and products will be used in

”ctownsend@jhu.edu. Corresponding Author: "phone/fax (410) 516-7444/(410) 261-1233 ctownsend@jhu.edu..

Associated Content

Supporting Information:

Copies of the ${ }^{1} \mathrm{H},{ }^{13} \mathrm{C}$ and ${ }^{31} \mathrm{P}$ NMR spectra of all new compounds. HPLC traces of thioesters with and without incubation in $50 \mathrm{mM}$

$\mathrm{K}_{\mathrm{i}} \mathrm{PO}_{4}, \mathrm{pH}$ 7.5. This material is available free of charge via the Internet at http://pubs.acs.org.

Notes

The authors declare no competing financial interest. 
mechanistic studies of the two nonribosomal peptide synthetases NocA and NocB that lie at the heart of nocardicin biosynthesis, a family of monocyclic $\beta$-lactam antibiotics.

\section{Introduction}

Four classes of naturally-occurring $\beta$-lactam antibiotics are currently known: penicillins, for example, the naturally-occurring penicillin $\mathrm{N}(\mathbf{1})$ and the oxidatively related cephalosporins and cephamycins, clavulanic acid (2) and the antipodal clavams, carbapenem-3-carboxylic acid (3) and more highly elaborated carbapenems, e.g. thienamycin, and the monocyclic $\beta$ lactams exemplified by nocardicin A (4). ${ }^{1}$ Ironically the last of these families, despite comparative structural simplicity, stubbornly remains the least understood biosynthetically. In only the last year the first experimental advances in a decade have been reported such that now central questions about how the peptide core of the nocardicins is constructed can be clearly defined. To rigorously address these questions we have developed and report here methods to prepare a series of sensitive peptide thioesters and their phosphorylated and $\beta$ lactam-containing derivatives in stereochemically controlled manner with the aim to serve as discriminating mechanistic probes of these early biochemical events.

In 2004 the gene cluster responsible for the biosynthesis of the nocardicins was isolated and characterized from Nocardia uniformis ssp. tsuyamanensis. ${ }^{2}$ Prominent among the encoded proteins was a pair of nonribosomal peptide synthetases (NRPSs), NocA and NocB, that together house five complete modules predicted to synthesize an L,L,D,L,L-pentapeptide and whose demonstrated amino acid substrates would be expected to form 5 (Figure 2). ${ }^{3}$ It is with this discovery, however, that the key unresolved questions can be posed. First, nocardicin $G(6)$, the earliest $\beta$-lactam-containing precursor of nocardicin A (4) contains a $\mathrm{D}, \mathrm{L}, \mathrm{D}-$ tripeptide, not a pentapeptide, core, and is stereochemically inconsistent with derivation from 5. ${ }^{4,5}$ With the troublesome identification of $\mathrm{L}_{\mathrm{L}}$ arginine as the amino acid specifically activated by module 2 of NocA, it would seem the initial two $N$-terminal amino acid residues of $\mathbf{5}$ are cleaved away during the biosynthesis of the antibiotic, and the $C$-terminal tripeptide arising from modules 3-5 is utilized by way of $\beta$-lactam formation and epimerization at the carboxy terminus to form nocardicin $G(\mathbf{6})$. The timing and mechanism of precursor peptide truncation, $\beta$-lactam formation and epimerization are not known, but can be addressed experimentally by the synthesis of now definable potential substrates for the biosynthetic system as set out in the following sections.

To achieve these goals several synthetic challenges intrinsic to peptide substrates rich in pHPG residues and serine had to be addressed. The first was establishing suitable chemical conditions that prevented racemization/epimerization of the unusually base-sensitive benzylic a-center of pHPG during peptide elongation. A second and related challenge entailed the selection of suitable orthogonal protecting groups that conformed with limitations that both excluded alkaline deblocking protocols and resulted in penultimate $N$ terminally protected peptides labile to acid deprotection after final thiol coupling. Third, the seryl hyrdroxymethylene was to be both activated to behave as a potential electrophile and incorporated into a $\beta$-lactam ring without trivial elimination to dehydroalanine. The fourth hurdle was separation and purification of diastereomers that were unavoidably generated during thioester formation.

\section{Results/Discussion}

\section{Synthesis of Potential Tri- and Pentapeptides in Nocardicin Biosynthesis}

Nonribosomal peptide synthases are giant modular enzymes that catalyze the assembly of a large number of bioactive peptides and peptide-derived natural products using the multiple 
carrier thiotemplate mechanism. ${ }^{6}$ In the NRPS paradigm each canonical module contains at least a basis set of three domains: an adenylation (A) domain, peptidyl-carrier protein (PCP) and condensation $(\mathrm{C})$ domain. The A-domain selectively recognizes and activates, with few exceptions, an L-a-amino acid in an ATP-dependent reaction (acyl-adenylation). This mixed anhydride reacts with the $S$-terminus of a phosphopantetheine arm, appended by posttranslational modification of the PCP domain, to give rise to the amino acid- $S$-PCP thioesters shown in Figure 2. ${ }^{7,8}$ For artificial substrate mimics, the $S$-PCP moiety has been successfully replaced either simply by $N$-acetylcysteamine (SNAC) or more accurately by pantetheine to which the terminal synthetic peptide is attached as its thioester. ${ }^{9,10}$ Chain elongation is carried out by condensation (C)-domains, which catalyze peptide bond synthesis between the upstream PCP-bound thioester and the downstream PCP-bound amino acid a-amine (Figure 2). Additionally, other editing domains may be present in NRPSs including epimerization (E) domains and $N$-methylation (M) domains. ${ }^{11}$ The final module found in these megasynthetases most often contains a $C$-terminal thioesterase (TE)-domain as seen in NocB, which catalyzes the disconnection of the full-length peptidyl chain from the adjacent PCP domain.

The modular organization of NocA/B and hypothetical stepwise assembly of the predicted L,L,D,L,L-pentapeptide $\mathbf{5}$ is illustrated in Figure 2. The stereochemistry is predicted based on the known amino acids activated in each domain ${ }^{12}$ and the presence or absence of epimerization domains. In particular, module 3 contains an epimerase domain $\left(\mathrm{E}_{3}\right)$, presumably accounting for the $N$-terminal D-configuration of nocardicin $\mathrm{G}$, while module 5 does not.

Of the three chemical events that must occur between the assembly of pentapeptide 5 and the synthesis of nocardicin $\mathrm{G}(\boldsymbol{6}), \beta$-lactam formation and $C$-terminal epimerization can only take place after the final pHPG addition in module 5. Truncation of the pentapeptide to the tripeptide core present in nocardicin G (D-pHPG-L-Ser-L-pHPG ultimately arising from modules 3-5) can logically occur before or after either or both of the other two reactions. The first synthetic task, therefore, was the preparation of two sets of peptide scaffolds varying in $C$-terminal stereochemistry: protected tripeptides 10a and 10b (D-pHPG-L-Ser-LDpHPG) and protected pentapeptides 16a and 16b (L-pHPG-L-Arg-D-pHPG-L-Ser-LD-pHPG, each of which could then be converted to the corresponding pantetheinyl thioester, appropriately primed for future enzymatic analysis.

At the outset it was anticipated that stereochemical control of the benzylic a-positions of pHPG units would be problematic based on earlier experience with partial and total syntheses of the nocardicins and vancomycin. ${ }^{4,13,14}$ The $\mathrm{pKa}$ of the a-hydrogen of a pHPG oxyester is estimated to be $\sim 23$ compared to $26-28$ for alanine or serine. ${ }^{15}$ Thioesters, however, are of particular interest in the present study and substantial depression of the pKa of the a-hydrogen of a pHPG occurs and is calculated to be $\sim 20$ for pHPG and 25-26 for alanine or serine. By extension, reductions in pKa can also be anticipated in active esters generated transiently during peptide coupling and thioester synthesis. As a consequence, orthogonal amino acid protections relied on blocking groups that could be removed by exposure to acid or by hydrogenolysis. Survey of available peptide coupling reagents demonstrated that benzotriazol-1-yl-oxytripyrrolidinophosphonium hexafluorophosphate (PyBOP) with the hindered base $N, N$-diisoproylethylamine (DIEA) was a suitable reagent combination in even the most polar of solvents including DMF, acetonitrile (ACN), and DCM, and took place without detectible epimerization in good yields. For the envisioned triand pentapeptides, the a-hydrogen of the pHPG units, whether $\mathrm{L}$-or $\mathrm{D}$-configured, were always adjacent to either, or both, $\mathrm{L}$-serine and $\mathrm{L}$-arginine and appeared as a simple doublet in $\mathrm{d}_{6}$-DMSO owing to vicinal coupling to the adjacent amide $\mathrm{N}-\mathrm{H}$. The chemical shift of this 
hydrogen in the ${ }_{\mathrm{D}}$-configuration was reliably diagnostic appearing upfield compared to the $\mathrm{L}_{\mathrm{-}}$ diastereomer.

The synthesis of the protected tripeptides $\mathbf{1 0 a}$ and $\mathbf{1 0 b}$ proceeded from the $C$ - to $N$-terminus in conventional fashion using $N$-Boc and benzyl protecting groups as illustrated in Scheme 1. The $p$-toluene sulfonate salt of the bis-benzyl L-or ${ }_{\mathrm{D}}-\mathrm{pHPG}, \mathbf{7} \mathbf{a}$ and $\mathbf{7 b}$ respectively, was coupled with Boc-s-serine, $N$-deprotected by brief TFA treatment and coupled again to BocD- $(p$ - benzyloxyphenyl)glycine 9 to give the diastereomeric protected tripeptides $\mathbf{1 0 a}$ or $\mathbf{1 0 b}$.

The protected pentapeptides 16a and 16b were synthesized in a convergent approach by combining L,L-dipeptide 15 with the diastereomeric tripeptides $10 \mathbf{a}$ and $\mathbf{1 0 b}$ after selective removal of blocking groups (Scheme 2 ). To use the commercially available $N$-a-Fmoc-NG (2,2,4,6,7-pentamethyldihydrobenzofuran-5-sulfonyl)-L-arginine (Fmoc-L-Arg(Pbf)-OH), it would be necessary to avoid the alkaline Fmoc deprotection in the presence of any pHPG groups or thioesters. Accordingly, Fmoc-L-Arg(Pbf)-OH was benzylated to 13, converted to its corresponding free base by treatment with $20 \%$ piperidine in THF and coupled to Boc-LpHPG to afford the differentially protected ${ }_{\mathrm{L}, \mathrm{L}}$-dipeptide 15 . Compound 10a or 10b was $N$ deblocked with TFA and joined with 15, after hydrogenolysis, to give the protected L,L,D,L,L/Dpentapeptides $\mathbf{1 6} \mathbf{a}$ or $\mathbf{1 6} \mathbf{b}$, respectively, with complete retention of all five stereocenters.

The benzyl protecting groups were removed from $\mathbf{1 6 a}$ and $\mathbf{1 6 b}$ by catalytic hydrogenation and the resulting $N$-Boc/Arg-Pbf pentapeptides were coupled to pantetheine dimethyl ketal $\mathbf{1 1}^{16}$ to give the corresponding protected thioesters. A mild aqueous workup was employed to wash away by-products and the desired Boc/Pbf-protected peptide thioester was extracted into organic solvent, concentrated in vacuo and re-dissolved in TFA. The final products 17a and 17b were purified by HPLC and lyophilized to dryness as their corresponding TFA salts. The pantetheine thioesters 12a and 12b (Scheme 1) were prepared analogously. While these tripeptide thioesters could be separated by HPLC, the pentapeptides $\mathbf{1 7} \mathbf{a}$ and $\mathbf{1 7 b}$ coelute.

The generation of a mixture of diastereomers at the relatively acidic $C$-terminal pHPG acenter proved unavoidable in the syntheses of pantetheinyl and $N$-acetylcysteaminyl (not shown) peptide thioesters. The peptide thioesters $12 \mathbf{a}$ and $\mathbf{1 2 b}$ could be individually purified by HPLC as noted above. When placed in $50 \mathrm{mM}$ phosphate buffer, $\mathrm{pH} 7.5$, the half-life of spontaneous epimerization at this a-center was estimated by HPLC analysis to be $\sim 3 \mathrm{~h}$.

\section{Synthesis of Potential O-Phosphoryl and O-Acetyl Substrates}

The $\beta$-lactam ring of nocardicin $\mathrm{A}$ is derived from $\mathrm{L}_{\mathrm{-}}$-serine in a process where no change in oxidation state occurs at the seryl $\beta$-carbon and clean stereochemical inversion is observed at this center. ${ }^{17-19}$ The simplest interpretation of these experimental observations, presuming the intermediacy of a peptide precursor, is intramolecular nucleophilic substitution $\left(\mathrm{S}_{\mathrm{N}} \mathrm{i}\right)$ of an activated seryl-hydroxyl in an amide-containing precursor, possibly through $O$ phosphorylation or activation by some other means. Chemical support for this hypothesis came when phosphorylation of serine was mimicked in vitro by reaction of a protected serine-containing dipeptide under Mitsunobu conditions, generating the $\beta$-lactam rapidly at room temperature. ${ }^{4,20} \mathrm{O}$-Phosphorylation is a particularly attractive route of seryl activation owing to the ubiquitous utilization of ATP in NRPS systems and the metabolic intermediacy of $O$-phosphoserine.

In considering the construction of $O$-phosphoryl tripeptides $18 \mathbf{a}$ and $\mathbf{1 8 b}$ (Scheme 3), one immediate concern was ready elimination under even weakly alkaline conditions to form an undesired dehydroalanine residue. To avoid this outcome, installation of a protected $O$ phosphoryl group was achieved through the use of phosphoramidite chemistry using 
tetrazole, a weak acid, in an approach analogous to oligonucleotide chemical synthesis. ${ }^{21,22}$ This transformation was then followed in the same pot by oxidation of the phosphite to the corresponding phosphate with a hindered hydroperoxide at low temperature to suppress potential nucleophilic displacement of the freshly generated protected $O$-phosphate and reforming the free seryl starting material.

In practice the $O$-phosphoryl functionality was installed in the protected tripeptide $10 \mathbf{a}$ or 10b by treatment with dibenzyl- $N, N$,-diisopropylphosphoramidite (dibenzyl-DIPA) and 4,5dicyanoimidazole (DCI), which was then oxidized with tert-butyl hydroperoxide to generate the benzyl protected $O$-phosphate analog of 18a or 18b. Although this reaction sequence met with great success, the final peptide coupling reaction to produce the desired products 19a and 19b failed under several conditions due to the presence of the seryl free phosphate and interference with coupling reagents. This failure was easily overcome by keeping the phosphate protected as an acid-labile di-tert-butyl-phosphate, which could be subsequently de-blocked after thiol condensation.

To this end, dibenzyl-DIPA was replaced with di-tert-butyl $N, N$-diisopropylphosphoramidite (di-tert-butyl-DIPA). Although reactions conducted with di-tert-butyl-DIPA and 4,5dicyanoimidazole repeatedly failed, presumably due to a suboptimal $\mathrm{pKa}$ differential, substitution with tetrazole proved to be successful. However, compared to dibenzylphosphoramidite, reactions with di-tert-butyl-phosphoramidite suffered from a longer reaction time, 6 hours vs. 15 minutes, and lower yields, 64\% vs. 78\%. This difference most likely owes to the relatively greater steric bulk of the tert-butyl analog, its greater sensitivity to moisture and the lower purity of the commercial reagent.

Of practical note, purification of protected phosphoryl peptides $\mathbf{1 8 a}$ and $\mathbf{1 8 b}$ was conducted in two stages. First, initial purification was conducted by silica gel chromatography in which the silica was pre-treated overnight with 5\% triethylamine. Chromatographic isolation of ditert-butyl-phosphoryl tripeptides $\mathbf{1 8 a}$ and $\mathbf{1 8 b}$ without prior silica gel deactivation resulted in partial deprotection of the di-tert-butyl- $O$-phosphoryl blocking groups. This decomposition was evident from both the low integration of the diastereomeric $O$-tert-butyl groups appearing as singlets at ca. $1.3 \mathrm{ppm}$ and $1.2 \mathrm{ppm}$ in ${ }^{1} \mathrm{H}-\mathrm{NMR}$ spectra and a downfield chemical shift of the proton- and carbon-decoupled phosphorous singlet from ca. -10 to -6 ppm in ${ }^{31} \mathrm{P}-\mathrm{NMR}$ spectra acquired in $\mathrm{d}_{6}$-DMSO. Silica gel purification after triethylamine treatment provided the desired compounds in $\sim 65 \%$ purity according to ${ }^{1} \mathrm{H}-\mathrm{NMR}$ spectroscopy. In a second step, crystallization of either diastereomer of the partially purified product from ether-hexanes provided the desired fully protected $O$-phosphorylated compounds $\mathbf{1 8 a}$ or $\mathbf{1 8 b}$ as colorless fine needles in $>99 \%$ purity. Each was devoid of both the diastereomeric impurity and the $\beta$-phosphate elimination product as established by ${ }^{1} \mathrm{H}$ NMR spectroscopic analysis. Compounds 18a and $\mathbf{1 8 b}$ were then subjected to hydrogenolysis, coupled to pantetheine dimethyl ketal 11 with PyBOP and $\mathrm{K}_{2} \mathrm{CO}_{3}$ in the usual manner, and the desired thioesters 19a and 19b were obtained after TFA deprotection and HPLC purification as an inseparable mixture of $C$-terminal diastereomers.

In addition to $O$-phosphorylation, $O$-acetylation was also envisioned as a possible means of seryl activation in vivo. Tripeptides $20 \mathbf{a}$ and $\mathbf{2 0 b}$ were generated simply by reacting one equivalent of acetic anhydride in pyridine with protected tripeptide 10a or 10b. The protected $O$-acetyl tripeptides 20a and 20b were isolated in quantitative yield with no formation of diastereomers. The desired thioester substrates $\mathbf{2 1 a}$ and $\mathbf{2 1 b}$ were obtained by hydrogenolysis of 20a and 20b, respectively, followed by PyBOP coupling to pantetheine dimethyl ketal 11, TFA deprotection and HPLC purification of the separable diastereomers. 


\section{Synthesis of Potential $\beta$-lactam Containing Thioester Substrates}

The nocardicins share with penicillin N (1) central NRPSs that synthesize their fundamental peptide precursors. The tripeptide core of the latter, $\delta$-(L-C-aminoadipoyl)-L-cysteinyl-Dvaline (ACV), is produced by and released from ACV synthetase. This L,L,D-tripeptide is doubly cyclized by isopenicillin $\mathrm{N}$ synthase to $1 .^{23,24}$ Hydrolysis of a three- or five-amino acid peptide is similarly expected from NocA/B. As noted at the outset, however, the timing of pentapeptide truncation, $C$-terminal epimerization and $\beta$-lactam formation is not known. As a final set of reference standards and potential substrates to examine these questions, the last synthetic goal was the preparation of two sets of pantetheinyl and $\beta$-lactam containing peptides varying in $C$-terminal stereochemistry: epi-nocardicin G- and nocardicin Gpantetheine 29a and 29b in addition to L-pHPG-L-Arg-epi-nocardicin G- and L-pHPG-L-Argnocardicin G-SNAC 31a and 31b.

The desired $\beta$-lactam peptidyl thioesters epi-nocardicin G-pantetheine 29a and nocardicin Gpantetheine 29b were first constructed as a peptide scaffold in a $C$ - to $N$-terminal fashion through the central intermediacy of tert-butyl 3-aminocardicinate (epi-3-ANA 25a or 3ANA 25b) in a manner analogous to published nocardicin syntheses ${ }^{4}$ (Scheme 4). To this end, Sheehan's 4,5-diphenyl-4-oxazolin-2-one (Ox) $N$-protecting group was used as a means of bi-dentate ligation of the serine nitrogen, preventing competing aziridine formation in the downstream Mitsunobu cyclodehydration reaction. ${ }^{25,26}$ Moreover, dipeptides Ox-L-Ser-LpHPG and Ox-L-Ser-D-pHPG, 23a and 23b respectively, were prepared from one unit of either $\mathrm{L}$ or $\mathrm{D}$-tert-butyl-benzyloxy-pHPG (22a or 22b) and Ox-L-Ser in a PyBOP mediated reaction, which provided the products in high yield with no pHPG epimerization detectable by ${ }^{1} \mathrm{H}$-NMR spectroscopy. Protected $\beta$-lactam intermediates $\mathbf{2 4 a}$ and $\mathbf{2 4 b}$ were successfully generated from seryl-dipeptides 23a and $\mathbf{2 3 b}$ with retention of stereochemistry at the pHPG a-center through a modification of the classical Mitsunobu reaction procedure in which $\mathrm{PPh}_{3}$ was replaced with $\mathrm{P}(\mathrm{OEt})_{3}$; a reaction explored more fully elsewhere. ${ }^{20,27}$

Hydrogenolysis of $\mathbf{2 4 a}$ or $\mathbf{2 4} \mathbf{b}$ followed by aqueous acidic extraction and lyophilization afforded the desired central intermediates epi-3-ANA. $\mathrm{HCl}$ 25a and 3-ANA.HCl 25b respectively as white salts.

Of particular note, it was discovered here that excluding light from the modified Mitsunobu conditions allowed for reaction yields as high as $96 \%$, an improvement from the previously reported $84 \%$ yield and a cleaner workup. It is suggested that the omission of light reduces or eliminates DEAD degradation. In a mechanistic study of the Mitsunobu esterification reaction, Hughes et al. discovered that in all solvents examined, formation of the DEAD and $\mathrm{PPh}_{3}$ adduct occurs more rapidly than either the subsequent alcohol activation to form the oxyphosphonium intermediate or the ensuing $\mathrm{S}_{\mathrm{N}} 2$ displacement. ${ }^{28}$ In the present case where $\mathrm{P}(\mathrm{OEt})_{3}$ is substituted for $\mathrm{PPh}_{3}$, the formation of the adduct between DEAD and $\mathrm{P}(\mathrm{OEt})_{3}$ may progress at a comparatively slower rate leaving the DEAD free to photodecompose before it is fully consumed. This factor could account for lower overall yields and product purity. In view of these observations, both reaction yields and ease of product purification for all Mitsunobu-type transformations may greatly benefit from the exclusion of light.

With the key dipeptide $\beta$-lactam-containing intermediates in hand, syntheses of the protected epi-nocardicin G 28a and nocardicin G 28b were achieved through the condensation of BocD-pHPG 26 and epi-3-ANA 25a or 3-ANA 25b, respectively, by way of modified Vaughan conditions for the generation of mixed anhydrides from isobutylchloroformate. ${ }^{29}$ Although the reactions to form $\mathbf{2 8} \mathbf{a}$ or $\mathbf{2 8 b}$ involved amide bond formation of an unhindered carboxylic acid $\mathbf{2 6}$ and primary amines $\mathbf{2 5 a}$ or $\mathbf{2 5 b}$, modern coupling reagents that proceed through the generation of an active ester, such as PyBOP, ${ }^{30} \mathrm{COMU},{ }^{31} \mathrm{EDC}$ and DCC, ${ }^{32}$ all afforded poor $(<10 \%)$ to no observable yields of product under standard conditions. To 
overcome this unexpected setback, the desired protected $\beta$-lactam products $\mathbf{2 8 a}$ and $\mathbf{2 8 b}$ were prepared through in situ generation of a mixed anhydride followed by the addition of $\mathbf{2 5} \mathbf{a}$ or $\mathbf{2 5} \mathbf{b} .{ }^{33}$ It was found that reactions to produce protected epi-nocardicin G 28a and protected nocardicin $\mathrm{G} \mathrm{28b}$ from the condensation of $\mathbf{2 6}$ and either $\mathbf{2 5 a}$ or $\mathbf{2 5} \mathbf{b}$ required the addition of $N$-methylmorpholine. Production of the mixed anhydride was monitored by the reliably diagnostic precipitation of protonated 2,6-lutidine. Conversely, when $N$ methylmorpholine is omitted from the reaction, a salt does not form and amide bond formation is not observed. By supplementation with $N$-methylmorpholine according to the

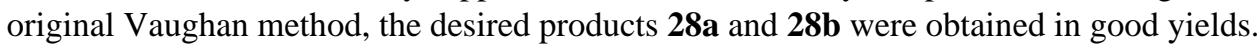

With improved syntheses of protected nocardicin $\mathrm{G}$ and epi-nocardicin $\mathrm{G}$ established, the desired thioesters epi-nocardicin G-pantetheine 29a and nocardicin G-pantetheine 29b were synthesized from either diastereomer of the Boc protected nocardicin G (28a or $\mathbf{2 8 b})$ by PyBOP coupling followed by pantetheine attachment. Acidic deprotection (TFA) produced the final thioesters as a mixture of $C$-terminal diastereomers in an equilibrium ratio of 1:1.1 29a: 29b. The diastereomers were separable by HPLC purification under acidic conditions. Substrates 30a and 30b were obtained similarly by substitution of SNAC for the pantetheine dimethyl ketal 11.

Bearing the planned biochemical experiments in mind, the intrinsic rate of epimerization at the thioester a-center was determined by HPLC time-course analysis of purified nocardicin G-SNAC 30b in $50 \mathrm{mM}$ phosphate buffer at pH 7.5 (Figure 3). The rate of spontaneous epimerization of nocardicin G-SNAC 30b to epi-nocardicin G-SNAC 30a was measured to be $5.5 \pm 0.2 \times 10^{-4} \mathrm{sec}^{-1}\left(\mathrm{k}_{1}+\mathrm{k}_{2}\right)$ corresponding to a half life of $\sim 21 \mathrm{~min}$. Dynamic equilibrium of the two diastereomers is achieved in less than 3 hours, resulting in a 1.1: 1 nocardicin G-SNAC: epi-nocardicin G-SNAC ratio. The slightly thermodynamically preferred thioester 30b contains a $C$-terminal $\mathrm{D}$-pHPG, identical to the biologically observed nocardicin stereoisomer. By comparison to the pantetheinyl-tripeptides $\mathbf{1 2} \mathbf{a}$ and $\mathbf{1 2 b}$, the rate of chemical epimerization of the $\beta$-lactam containing compounds is $c a$. 10x faster.

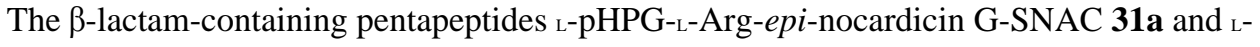
pHPG-L-Arg-nocardicin G-SNAC 31b were synthesized in a convergent approach utilized similarly above for pentapeptides $\mathbf{1 6 a}$ and $\mathbf{1 6 b}$ by combining the free acid of dipeptide $\mathbf{1 5}$ and the free base of either epi-nocardicin G-SNAC 30a or nocardicin G-SNAC 30 (Scheme 5 ). Unlike the previous syntheses reported here in which an $N$-Boc protected peptide intermediates were coupled to the desired thiol as the penultimate step prior to final deprotection, the synthesis of compounds $\mathbf{3 1 a}$ and $\mathbf{3 1 \mathbf { b }}$ required the formation of the thioester before final amide bond condensation due to both the absence of a $C$-terminally protected carboxylic acid in compounds $\mathbf{2 8 a}$ and $\mathbf{2 8 b}$ and the restrictions of protecting group orthogonality resulting in an $N$-Boc protected compound. Pentapeptide $\beta$-lactams 31a and 31b could be obtained as a mixture of $C$-terminal diastereomers by condensation of dipeptide 15 and pre-installed SNAC thioesters 30a or 30b. TFA deprotection produced the desired products as a separable mixture of diastereomers, which were HPLC purified under acidic conditions.

\section{Conclusion}

Syntheses of tri- and pentapeptides incorporating seryl, $O$-phosphoseryl and $\beta$-lactam moieties have been developed to study monocyclic $\beta$-lactam antibiotic biosynthesis. The $O$ phosphoryl modification was achieved without competing formation of dehydroalanyl $\beta$ elimination products, and 4-membered ring closures of seryl residues to the $\beta$-lactam could be carried out without accompanying epimerization in a modified Mitsunobu reaction where $\mathrm{P}(\mathrm{OEt})_{3}$ replaced conventionally used $\mathrm{PPh}_{3}$. 
During this phase of the work, it was observed that protection of the reaction from ambient light by wrapping the reaction flask in aluminum foil raised the yield of the Mitsunobu ring formation to $>95 \%$ and simplified product isolation. We attribute the increased efficiency of this reaction to reduced photodecomposition of the DEAD reagent. Unexpected difficulty in peptide bond formation to the $\beta$-lactam $\beta$-amine could be overcome by resorting to classical mixed anhydride-mediated coupling, but only in the presence of catalytic $N$ methylmorpholine.

Through careful choice of appropriately orthogonal protecting groups, the absolute configuration of all a-centers was preserved, notably the especially acidic pHPG units, to assemble the tri- and pentapeptides 10a, 10b and 16a, 16b, respectively, with complete stereochemical control. Conversion of the $C$-terminal pHPG residue, however, to SNAC and pantetheine thioesters gave epimerization at the a-carbon that proved unavoidable, but for several of the final products, separation by HPLC was possible. Still, in aqueous buffer at room temperature, spontaneous epimerization occurred slowly in the peptide products, but ca. 10-fold more rapidly in the $\beta$-lactam thioesters with a half-life of ca. 20 minutes.

The non-proteinogenic amino acid pHPG appears often in NRPS-derived natural products apart from the nocardicins-notably the glycopeptides vancomycin, A47934, chloroeremomycin, complestatin, as well as other antimicrobial compounds such as ramoplanin and Streptomyces calcium-dependent antibiotics. The tactics and reaction conditions developed here will be of broader use in biosynthetic investigations of not only these pHPG-containing natural products but also those containing phenylglycine and 3,5dihydroxyphenylglycine residues. Biochemical experiments to address the central questions of pentapeptide truncation, $C$-terminal epimerization and $\beta$-lactam formation in the biosynthesis of the nocardicins will be addressed in due course.

\section{Experimental Section:}

\section{General Experimental Details}

${ }^{1} \mathrm{H}-\mathrm{NMR}$ spectra were recorded on a 400 or $600 \mathrm{MHz}$ spectromer. Proton chemical shifts are reported in ppm $(\delta)$ relative to internal tetramethylsilane (TMS, $\delta 0.0 \mathrm{ppm}$ ) or with the solvent reference relative to TMS $\left(\mathrm{D}_{2} \mathrm{O}, \delta 4.79 \mathrm{ppm}, \mathrm{CDCl}_{3}, \delta 7.26 \mathrm{ppm}\right.$, DMSO-d 6 , 2.50 $\mathrm{ppm}$ ). Data are reported as follows: chemical shift (multiplicity [singlet (s), doublet (d), triplet (t), quartet (q), and multiplet (m)], coupling constants [Hz], integration). ${ }^{13} \mathrm{C}-\mathrm{NMR}$ spectra were recorded on a $400(101 \mathrm{MHz})$ spectrometer with complete proton decoupling. Carbon chemical shifts are reported in ppm $(\delta)$ relative to TMS with the $\left(\mathrm{CD}_{3}\right)_{2} \mathrm{SO}(\delta 39.52$ $\mathrm{ppm})$ or $\mathrm{CDCl}_{3}(\delta 77.16 \mathrm{ppm})$ as the internal standard. ${ }^{31} \mathrm{P}-\mathrm{NMR}$ spectra were recorded on a $400(162 \mathrm{MHz})$ spectrometer with complete proton and carbon decoupling with no internal standard. High-resolution mass spectrometry was performed by either fast atom bombardment (FAB/magnetic sector) or electrospray ionization (ESI/IT-TOF). All specific rotations were acquired at $589 \mathrm{~nm}$. All melting points were uncorrected. All purchased chemical were used as received.

Preparative and analytical HPLC purifications were analyzed via a multi-wavelength UVVis detector in conjunction with a reverse-phase C18(2) preparatory column $(250 \times 21.20$ $\mathrm{mm}$ ID). Mobile phase conditions included one of the following: Prep Method A (water + acetonitrile $(\mathrm{ACN})+0.1 \% \mathrm{TFA}$ ): $0-5 \mathrm{~min}$ isocratic $13 \%$ water $87 \% \mathrm{ACN}+0.1 \%$ TFA, $5-25$ min gradient $13 \%$ to $50 \% \mathrm{ACN}+0.1 \%$ TFA, $25-30 \mathrm{~min} 50 \% \mathrm{ACN}$ to $13 \% \mathrm{ACN}, 30-35 \mathrm{~min}$ isocratic $13 \%$ water $87 \% \mathrm{ACN}+0.1 \%$ TFA. Flow rate $=6.5 \mathrm{~mL} / \mathrm{min}$. Prep Method B (water + ACN + 0.1\% TFA): $0-25$ min gradient $15-80 \% \mathrm{ACN}+0.1 \% \mathrm{TFA}, 25-30 \mathrm{~min} 80 \%$ to $15 \% \mathrm{ACN}+0.1 \% \mathrm{TFA}, 30-35 \min 15 \% \mathrm{ACN}+85 \%$ water $+0.1 \%$ TFA. Flow rate $=6.5$ $\mathrm{mL} / \mathrm{min}$. 
Analytical HPLC purifications were analyzed with a multi-wavelength UV-Vis detector in conjunction with a reverse phase phenyl hexyl analytical column $(250 \times 4.60 \mathrm{~mm}$ ID).

Analytical Method A (water + ACN + 0.1\% TFA): 0-5 min isocratic 93\% water + 7\% ACN $+0.1 \%$ TFA, $5-22$ min gradient $7 \%$ to $50 \% \mathrm{ACN}+0.1 \% \mathrm{TFA}, 22-25$ min gradient $50 \%$ to $7 \%$ ACN $+0.1 \%$ TFA, 25-35 min isocratic 93\% water $+7 \%$ ACN $+0.1 \%$ TFA. Flow rate $=$ $1.0 \mathrm{~mL} / \mathrm{min}$. Analytical Method B (water $+\mathrm{ACN}+0.1 \% \mathrm{TFA}$ ): $0-20$ gradient $7 \%$ to $50 \%$ $\mathrm{ACN}+0.1 \%$ TFA, $20-25$ min gradient $50 \%$ to $7 \% \mathrm{ACN}+0.1 \% \mathrm{TFA}, 25-35 \mathrm{~min}$ isocratic $93 \%$ water $+7 \%$ ACN $+0.1 \%$ TFA. Flow rate $=1.0 \mathrm{~mL} / \mathrm{min}$.

\section{Benzyl---[p-(benzyloxy)phenyl]glycine Toluenesulfonate (7a)}

To a $500 \mathrm{~mL}$ round-bottomed flask, equipped with a magnetic stir bar, $\mathrm{L}-[p$ (benzyloxy)phenyl]glycine ${ }^{14}(10.0 \mathrm{~g}, 38.9 \mathrm{mmol})$ was suspended in reagent grade benzyl alcohol $(100 \mathrm{~mL})$ and benzene $(140 \mathrm{~mL}) p$-toluene sulfonic acid monohydrate $(8.87 \mathrm{~g}, 46.7$ mmol) warmed to reflux under Dean-Stark conditions for $12 \mathrm{~h}$. The solution was cooled to room temperature and added directly to $500 \mathrm{~mL}$ of $\mathrm{Et}_{2} \mathrm{O}$. The precipitate was filtered and resuspended in $1 \mathrm{~L}$ of $\mathrm{Et}_{2} \mathrm{O}$ and vigorously stirred for $1 \mathrm{~h}$ to remove residual benzyl alcohol. The precipitate was filtered to afford the product as a white salt $(19.46 \mathrm{~g}, 96 \%) .[\mathrm{a}]_{\mathrm{D}}{ }^{26}=$ 26.3 (c = 1.0, MeOH); ${ }^{\mathbf{1}} \mathbf{H}-\mathrm{NMR}(400 \mathrm{MHz}$; DMSO-d6): $\delta 8.88(\mathrm{~s}, 3 \mathrm{H}), 7.54(\mathrm{~d}, J=8.1 \mathrm{~Hz}$, $2 \mathrm{H}), 7.47-7.23(\mathrm{~m}, 12 \mathrm{H}), 7.14(\mathrm{~d}, J=7.9 \mathrm{~Hz}, 2 \mathrm{H}), 7.08(\mathrm{~d}, J=8.8 \mathrm{~Hz}, 2 \mathrm{H}), 5.31(\mathrm{~s}, 1 \mathrm{H})$, 5.24, $5.19\left(\mathrm{ABq}, J_{\mathrm{AB}}=12.4 \mathrm{~Hz}, 2 \mathrm{H}\right), 5.15(\mathrm{~s}, 2 \mathrm{H}), 2.29$ (s, 3H). ${ }^{\mathbf{1 3}} \mathbf{C}-\mathbf{N M R}(101 \mathrm{MHz}$, DMSO-d6): $\delta$ 168.5, 159.2, 145.3, 138.0, 136.8, 135.1, 129.8, 128.5, 128.5, 128.3, 128.2, 128.1, 128.0, 127.9, 127.7, 126.6, 125.6, 124.5, 115.3, 69.3, 67.2, 63.0, 55.0, 20.9. HRMS (FAB) calculated for $\mathrm{C}_{22} \mathrm{H}_{22} \mathrm{NO}_{3} 348.15997$; Found $348.15966[\mathrm{M}+\mathrm{H}]^{+}$.

\section{Benzyl- o-[p-(benzyloxy)phenyl]glycine Toluenesulfonate (7b)}

The title compound was prepared and purified analogously to compound $7 \mathbf{a}$ by replacing $\mathrm{L}^{-}$ [ $p$-(benzyloxy)phenyl]glycine with $\mathrm{D}_{-}[p$-(benzyloxy)phenyl]glycine $(10.0 \mathrm{~g}, 38.9 \mathrm{mmol})$. The product was obtained as a white salt $(19.46 \mathrm{~g}, 96 \%)$. $[\mathrm{a}]_{\mathrm{D}}^{23}=-116.3(\mathrm{c}=1.0, \mathrm{EtOAc})$. $[\mathrm{a}]_{\mathrm{D}}{ }^{26}=-21.3(\mathrm{c}=1.0, \mathrm{MeOH}) ;{ }^{1} \mathbf{H}-\mathbf{N M R}(400 \mathrm{MHz}$; DMSO-d 6 ): $\delta 8.88(\mathrm{br} \mathrm{s}, 3 \mathrm{H}), 7.54$ $(\mathrm{d}, J=8.1 \mathrm{~Hz}, 2 \mathrm{H}), 7.47-7.23(\mathrm{~m}, 12 \mathrm{H}), 7.14(\mathrm{~d}, J=7.9 \mathrm{~Hz}, 2 \mathrm{H}), 7.08(\mathrm{~d}, J=8.8 \mathrm{~Hz}, 2 \mathrm{H})$, $5.31(\mathrm{~s}, 1 \mathrm{H}), 5.24,5.19\left(\mathrm{ABq}, \mathrm{J}_{\mathrm{AB}}=12.4 \mathrm{~Hz}, 2 \mathrm{H}\right), 5.15(\mathrm{~s}, 2 \mathrm{H}), 2.29(\mathrm{~s}, 3 \mathrm{H}) .{ }^{13} \mathbf{C}-\mathbf{N M R}$ $(101 \mathrm{MHz}$, DMSO-d 6 ): $\delta 169.0,159.6,145.9,138.3,137.2,135.6,130.2,129.0,128.9$, 128.8, 128.6, 128.5, 128.4, 128.3, 128.2, 126.9, 126.0, 125.0, 116.0, 69.7, 67.7, 63.4, 55.4, 21.3. HRMS (FAB) calculated for $\mathrm{C}_{22} \mathrm{H}_{22} \mathrm{NO}_{3}$ 348.15997; Found $348.15923[\mathrm{M}+\mathrm{H}]^{+}$.

\section{N-tert-Butyloxycarbonyl-ı-serine---[p-(benzyloxy)phenyl]glycine benzyl ester (8a)}

To a $250 \mathrm{~mL}$ round-bottomed flask equipped with a magnetic stir bar, Boc-s-serine $(4.0 \mathrm{~g}$, $19.49 \mathrm{mmol})$ and DIEA $(2.52 \mathrm{~mL}, 19.49 \mathrm{mmol})$ was dissolved in $30 \mathrm{~mL}$ of freshly distilled DCM and $10 \mathrm{~mL}$ of reagent grade DMF and cooled to $0{ }^{\circ} \mathrm{C}$ in an ice-bath. In a separate flask 7a $(10.12 \mathrm{~g}, 19.49 \mathrm{mmol})$ was dissolved in $30 \mathrm{~mL}$ of reagent grade DMF and to this suspension was added DIEA $(5.03 \mathrm{~mL}, 38.98 \mathrm{mmol})$ and cooled to $0{ }^{\circ} \mathrm{C}$ with an ice-bath. When both solutions had come to temperature, PyBOP $(11.16 \mathrm{~g}, 21.49 \mathrm{mmol})$ was added to the flask containing Boc-L-Ser. After 1 min, the amine solution containing 7a was added drop-wise over 2 min to the activated carboxylic acid and the reaction mixture was allowed to stir at $0{ }^{\circ} \mathrm{C}$ to room temperature for $3 \mathrm{~h}$. The solution was diluted with $200 \mathrm{~mL}$ of EtOAc and washed with sat. aq. $\mathrm{NH}_{4} \mathrm{Cl}(2 \times 75 \mathrm{~mL})$, sat. aq. $\mathrm{NaHCO}_{3}(2 \times 75 \mathrm{~mL})$ and brine $(1 \times$ $75 \mathrm{~mL}$ ). The organic layer was concentrated in vacuo and purified by silica gel chromatography with a gradient of 40: 60 EtOAc: Hex to 50: 50 EtOAc: Hex over $3 \mathrm{~L}$ to obtain the product as a white foam $(7.87 \mathrm{~g}, 76 \%)$. $[\mathrm{a}]_{\mathrm{D}}{ }^{22}=42.8\left(\mathrm{c}=1.0\right.$, EtOAc); ${ }^{1} \mathbf{H}-\mathbf{N M R}$ $\left(400 \mathrm{MHz}\right.$; DMSO-d $\left.{ }_{6}\right): \delta 8.55(\mathrm{~d}, J=6.8 \mathrm{~Hz}, 1 \mathrm{H}), 7.46-7.21(\mathrm{~m}, 12 \mathrm{H}), 7.00(\mathrm{~d}, J=8.8 \mathrm{~Hz}$, $2 \mathrm{H}), 6.75(\mathrm{~d}, J=8.4 \mathrm{~Hz}, 1 \mathrm{H}), 5.41(\mathrm{~d}, J=6.8 \mathrm{~Hz}, 1 \mathrm{H}), 5.13,5.10\left(\mathrm{ABq}, J_{A B}=12.8 \mathrm{~Hz}, 2 \mathrm{H}\right)$, 
$5.12(\mathrm{~s}, 2 \mathrm{H}), 4.80(\mathrm{t}, J=5.8 \mathrm{~Hz}, 1 \mathrm{H}), 4.11(\mathrm{q}, J=6.2 \mathrm{~Hz}, 1 \mathrm{H}), 3.61-3.56(\mathrm{~m}, 1 \mathrm{H})$, 3.53-3.47 (m, 1H), 1.37 (s, 9H). ${ }^{13}$ C-NMR (101 MHz, DMSO-d 6 ): $\delta$ 170.4, 170.3, 158.3, 155.2, 137.0, 136.7, 129.0, 128.4, 128.3, 128.2, 128.0, 127.8, 127.6, 127.5, 114.9, 78.2, 69.2, 66.2, 61.9, 56.6, 55.7, 28.2. HRMS (FAB) calculated for $\mathrm{C}_{30} \mathrm{H}_{34} \mathrm{~N}_{2} \mathrm{O}_{7}$ 535.2443; Found $535.24361[\mathrm{M}+\mathrm{H}]^{+}$.

\section{N-tert-Butyloxycarbonyl-_-serine-o-[p-(benzyloxy)phenyl]glycine benzyl ester (8b)}

The title compound was prepared and purified analogously to compound 8a by replacing 7a with $7 \mathbf{b}(10.0 \mathrm{~g}, 49.4 \mathrm{mmol})$. The product was obtained as a white foam $(7.87 \mathrm{~g}, 76 \%)$. [a $]_{\mathrm{D}}{ }^{22}$ $=-43.2\left(\mathrm{c}=1.0\right.$, EtOAc); ${ }^{\mathbf{H}} \mathbf{H}-\mathbf{N M R}\left(400 \mathrm{MHz} ;\right.$ DMSO-d $\left._{6}\right): \delta 8.57(\mathrm{~d}, J=7.2 \mathrm{~Hz}, 1 \mathrm{H})$, 7.47-7.23 (m, 12H), $7.01(\mathrm{~d}, J=8.8 \mathrm{~Hz}, 2 \mathrm{H}), 6.68(\mathrm{~d}, J=8.4 \mathrm{~Hz}, 1 \mathrm{H}), 5.44(\mathrm{~d}, J=7.2 \mathrm{~Hz}$, $1 \mathrm{H}), 5.14,5.12\left(\mathrm{ABq}, J_{A B}=12.7 \mathrm{~Hz}, 2 \mathrm{H}\right), 5.12(\mathrm{~s}, 2 \mathrm{H}), 4.87(\mathrm{br} \mathrm{t}, J=5.8 \mathrm{~Hz}, 1 \mathrm{H}), 4.18(\mathrm{br}$ q, $J=6.9 \mathrm{~Hz}, 1 \mathrm{H}), 3.56(\mathrm{t}, J=5.6 \mathrm{~Hz}, 2 \mathrm{H}), 1.40(\mathrm{~s}, 9 \mathrm{H}) .{ }^{13} \mathrm{C}-\mathrm{NMR}(101 \mathrm{MHz}$, DMSO-d 6 ): $\delta 170.9,170.8,158.7,155.6,137.5,136.2,129.3,128.9,128.8,128.7,128.4,128.3,128.1$, 128.0, 115.4, 78.7, 69.7, 66.7, 62.5, 56.9, 56.2, 28.6. HRMS (FAB) calculated for $\mathrm{C}_{30} \mathrm{H}_{34} \mathrm{~N}_{2} \mathrm{O}_{7}$ 535.2443; Found 535.24288 [M+H] ${ }^{+}$.

\section{N-tert-Butyloxycarbonyl-o-p-(benzyloxy)phenyl]glycine (9)}

To a $500 \mathrm{~mL}$ Erlenmeyer flask equipped with a magnetic stir bar, $\mathrm{D}-[p-$ (benzyloxy)phenyl]glycine (10.00 g, $38.87 \mathrm{mmol}$ ) was dissolved in $250 \mathrm{~mL}$ of $0.5 \mathrm{M} \mathrm{NaOH}$ (aq.) and to this solution was added di-tert-butyl dicarbonate $(9.33 \mathrm{~g}, 42.75 \mathrm{mmol})$ in 300 $\mathrm{mL}$ of reagent grade THF. The reaction was stirred at room temperature for $12 \mathrm{~h}$. The mixture was transferred to a 1-L separatory flask and the THF was partitioned from the aqueous fraction with $200 \mathrm{~mL}$ of $\mathrm{Et}_{2} \mathrm{O}$ and removed. The aqueous layer was transferred to a 1-L Erlenmeyer flask, cooled to $0{ }^{\circ} \mathrm{C}$ in an ice-bath and acidified to $\mathrm{pH} 2.0$ with conc. $\mathrm{HCl}$. The acidified aqueous mixture was extracted with EtOAc $(3 \times 100 \mathrm{~mL})$, the organic extractions were pooled and washed with brine $(1 \times 75 \mathrm{~mL})$ and concentrated in vacuo to afford the product as a white foam $(10.28 \mathrm{~g}, 74 \%)$. $[\mathrm{a}]_{\mathrm{D}}{ }^{25}=-93.3(\mathrm{c}=1.0, \mathrm{MeOH}) .{ }^{\mathbf{1}} \mathbf{H}-$ NMR (400 MHz; DMSO-d 6 ): $\delta$ 7.44-7.30 (m, 8H), $6.96(\mathrm{~d}, J=8.8 \mathrm{~Hz}, 2 \mathrm{H}), 5.08(\mathrm{~s}, 2 \mathrm{H})$, $5.02(\mathrm{~d}, J=8.0 \mathrm{~Hz}, 1 \mathrm{H}), 1.38(\mathrm{~s}, 9 \mathrm{H}) .{ }^{13} \mathrm{C}-\mathrm{NMR}\left(101 \mathrm{MHz}, \mathrm{DMSO}_{6}\right): \delta 172.6,157.9$, 155.1, 137.1, 130.3, 128.9, 128.5, 127.8, 127.6, 114.5, 78.2, 69.2, 57.3, 28.2. HRMS (FAB) calculated for $\mathrm{C}_{20} \mathrm{H}_{23} \mathrm{NO}_{5} 358.16545$; Found $358.16500[\mathrm{M}+\mathrm{H}]^{+}$.

\section{$N$-tert-Butyloxycarbonyl-o-[p-(benzyloxy)phenyl]glycine---serine---[ $p$ - (benzyloxy)phenyl]glycine benzyl ester (10a)}

To a $250 \mathrm{~mL}$ round-bottomed flask equipped with a magnetic stir bar, $8 \mathbf{a}(7.87 \mathrm{~g}, 14.72$ mmol) was dissolved in $100 \mathrm{~mL}$ of a 1:3 DCM: TFA solution and stirred at room temperature for $30 \mathrm{~min}$. The solution was concentrated in vacuo and residual TFA was removed by azeotropic distillation with toluene $(2 \times 75 \mathrm{~mL})$ and placed under high vacuum for $20 \mathrm{~min}$.

In a separate $250 \mathrm{~mL}$ round-bottomed flask equipped with a magnetic stir bar, $9(5.26 \mathrm{~g}$, $14.72 \mathrm{mmol})$ and DIEA $(2.56 \mathrm{~mL}, 14.72 \mathrm{mmol})$ were dissolved in $30 \mathrm{~mL}$ of reagent grade $\mathrm{DMF}$ and cooled to $0{ }^{\circ} \mathrm{C}$ in an ice-bath. The freshly deprotected $8 \mathbf{a}$ was separately dissolved in $30 \mathrm{~mL}$ of reagent grade DMF, DIEA $(5.12 \mathrm{~mL}, 29.44 \mathrm{mmol})$ was added and the solution was cooled to $0{ }^{\circ} \mathrm{C}$ in an ice-bath. When both solutions were sufficiently cooled, PyBOP $(11.16 \mathrm{~g}, 21.49 \mathrm{mmol})$ was added to the flask containing 9 . After $1 \mathrm{~min}$ the solution containing $8 \mathbf{a}$ was added drop-wise over $2 \mathrm{~min}$ to the activated carboxylic acid and the reaction was allowed to stir $0{ }^{\circ} \mathrm{C}$ to room temperature for $3 \mathrm{~h}$. The reaction was diluted with $200 \mathrm{~mL}$ of EtOAc and washed with sat. aq. $\mathrm{NH}_{4} \mathrm{Cl}(2 \times 75 \mathrm{~mL})$, sat. aq. $\mathrm{NaHCO}_{3}(2 \times 75$ $\mathrm{mL})$ and brine $(1 \times 75 \mathrm{~mL})$. The organic layer was concentrated in vacuo and the product 
was purified by silica gel chromatography with a gradient of 60: 40 EtOAc: Hex to 70: 30 EtOAc: Hex over $3 \mathrm{~L}$ to afford the product as a white foam $(8.00 \mathrm{~g}, 70 \%)$. $[\mathrm{a}]_{\mathrm{D}}{ }^{25}=0.2(\mathrm{c}=$ 1.0, EtOAc); ${ }^{1}$ H-NMR (400 MHz; DMSO-d 6$): \delta 8.64(\mathrm{~d}, J=6.4 \mathrm{~Hz}, 1 \mathrm{H}), 8.24(\mathrm{~d}, J=7.6$ $\mathrm{Hz}, 1 \mathrm{H}), 7.44-7.23(\mathrm{~m}, 20 \mathrm{H}), 7.01(\mathrm{~d}, J=8.8 \mathrm{~Hz}, 2 \mathrm{H}), 6.94(\mathrm{~d}, J=8.8 \mathrm{~Hz}, 2 \mathrm{H}), 5.42(\mathrm{~d}, J=$ $6.8 \mathrm{~Hz}, 1 \mathrm{H}), 5.22(\mathrm{~d}, J=8.4 \mathrm{~Hz}, 1 \mathrm{H}), 5.11(\mathrm{~s}, 4 \mathrm{H}), 5.07(\mathrm{~s}, 2 \mathrm{H}), 4.87(\mathrm{t}, J=5.3 \mathrm{~Hz}, 1 \mathrm{H})$, 4.41 (br q, $J=6.6 \mathrm{~Hz}, 1 \mathrm{H}), 3.55$ (br t, $J=5.3 \mathrm{~Hz}, 2 \mathrm{H}), 1.36(\mathrm{~s}, 9 \mathrm{H}) .{ }^{13} \mathrm{C}-\mathbf{N M R}(101 \mathrm{MHz}$, DMSO-d $\left.{ }_{6}\right): \delta 170.4,170.3,169.9,158.3,157.7,154.8,154.8,137.1,137.0,135.8,131.2$, $129.1,128.5,128.5,128.4,128.3,128.0,128.0,127.9,127.8,127.6,127.6,127.5,114.9$, 114.4, 78.4, 69.2, 69.2, 66.1, 61.6, 57.1, 55.9, 54.8, 28.2. HRMS (FAB) calculated for $\mathrm{C}_{45} \mathrm{H}_{45} \mathrm{~N}_{3} \mathrm{O}_{9}$ 774.33906; Found 774.33708 [M+H] ${ }^{+}$.

\section{N-tert-Butyloxycarbonyl-o-[p-(benzyloxy)phenyl]glycine--s-serine-o-[p- (benzyloxy)phenyl]glycine benzyl ester (10b)}

The title compound was prepared and purified analogously to compound $\mathbf{1 0 a}$ by replacing 8a with $8 \mathbf{b}$ (7.87 g, $14.72 \mathrm{mmol})$. The product was obtained as a white foam $(8.23 \mathrm{~g}, 72 \%)$. $[\mathrm{a}]_{\mathrm{D}}{ }^{25}=-62.0\left(\mathrm{c}=1.0\right.$, EtOAc); ${ }^{1} \mathrm{H}-\mathbf{N M R}(400 \mathrm{MHz}$; DMSO-d 6$): \delta 8.66(\mathrm{~d}, J=6.9 \mathrm{~Hz}$, $1 \mathrm{H}), 8.23(\mathrm{~d}, J=7.8 \mathrm{~Hz}, 1 \mathrm{H}), 7.467 .23(\mathrm{~m}, 20 \mathrm{H}), 7.01(\mathrm{~d}, J=8.8 \mathrm{~Hz}, 2 \mathrm{H}), 6.93(\mathrm{~d}, J=8.8$ $\mathrm{Hz}, 2 \mathrm{H}), 5.45(\mathrm{~d}, J=7.1 \mathrm{~Hz}, 1 \mathrm{H}), 5.24(\mathrm{~d}, J=8.1 \mathrm{~Hz}, 1 \mathrm{H}), 5.16,5.13\left(\mathrm{ABq}, J_{A B}=12.5 \mathrm{~Hz}\right.$, 2H), $5.12(\mathrm{~s}, 2 \mathrm{H}), 5.08(\mathrm{~s}, 2 \mathrm{H}), 4.90(\mathrm{t}, J=5.2 \mathrm{~Hz}, 1 \mathrm{H}), 4.44(\mathrm{br} \mathrm{q}, J=6.1 \mathrm{~Hz}, 1 \mathrm{H})$, 3.56-3.44 (m, $J=5.2 \mathrm{~Hz}, 2 \mathrm{H}), 1.36(\mathrm{~s}, 9 \mathrm{H}) .{ }^{13} \mathrm{C}-\mathbf{N M R}\left(101 \mathrm{MHz}, \mathrm{DMSO}-\mathrm{d}_{6}\right): \delta 170.8$, $170.4,158.7,158.2,137.55,137.5,136.2$, 131.5, 129.4, 129.0, 128.92, 128.89, 128.83, $128.79,128.6,128.4,128.32,128.28,128.1,128.0,115.3,114.9,78.9,69.69,69.65,66.6$, 62.2, 56.3, 55.2, 28.6. HRMS (FAB) calculated for $\mathrm{C}_{45} \mathrm{H}_{47} \mathrm{~N}_{3} \mathrm{O}_{9}$ 774.33906; Found $774.33786[\mathrm{M}+\mathrm{H}]^{+}$.

\section{Pantetheine dimethyl ketal (11)}

To a $500 \mathrm{~mL}$ round-bottomed flask, equipped with a magnetic stir bar, D-pantothenic acid hemicalcium salt $(5.00 \mathrm{~g}, 10.49 \mathrm{mmol}), p$-toluenesulfonic acid monohydrate $(4.79 \mathrm{~g}, 25.18$ $\mathrm{mmol}$ ) and $5.00 \mathrm{~g}$ of $3 \AA \AA$ 品olecular sieves were suspended in $250 \mathrm{~mL}$ of reagent grade acetone. The flask was capped and the suspension was stirred at room temperature for $12 \mathrm{~h}$. The thick slurry was filtered through Celite and washed with $3 \times 100 \mathrm{~mL}$ of acetone and the filtrate was concentrated to a viscous oil. The oil was dissolved in $200 \mathrm{~mL}$ of EtOAc, washed with brine $(2 \times 100 \mathrm{~mL})$ and further dried with $\mathrm{Na}_{2} \mathrm{SO}_{4}$. The EtOAc was removed in vacuo and just before the EtOAc was fully removed, hexane was added slowly to precipitate a solid that was dried under high vacuum and used in the next step without further purification.

To a $250 \mathrm{~mL}$ round-bottomed flask equipped with a magnetic stir bar, freshly prepared $\mathrm{D}^{-}$ pantothenic dimethyl ketal $(3.69 \mathrm{~g}, 14.23 \mathrm{mmol})$ was dissolved in $90 \mathrm{~mL}$ of freshly distilled THF, and treated with $1^{\prime}, 1^{\prime}$-carbonyldiimidazole $(3.46 \mathrm{~g}, 21.34 \mathrm{mmol})$ and stirred for $1 \mathrm{~h}$ at room temperature. To this solution was added cysteamine hydrochloride $(2.42 \mathrm{~g}, 21.34$ $\mathrm{mmol}$ ) and stirred at room temperature for $12 \mathrm{~h}$. The THF was concentrated in vacuo and $100 \mathrm{~mL}$ of DCM was added. The organic solution was washed sat. aq. $\mathrm{NH}_{4} \mathrm{Cl}(1 \times 50 \mathrm{~mL})$ and brine $(1 \times 50 \mathrm{~mL})$, dried with $\mathrm{Na}_{2} \mathrm{SO}_{4}$ filtered and concentrated to an oil. The oil was purified by silica gel flash chromatography with a mobile phase of 70:30 EtOAc: Hex to $100 \%$ EtOAc to produce the desired product as a white solid $(2.71 \mathrm{~g}, 81 \%)$. [a $]_{\mathrm{D}}^{23}=33.4$ (c $=1.0, \mathrm{MeOH}) .{ }^{1} \mathbf{H}-\mathbf{N M R}\left(400 \mathrm{MHz} ; \mathrm{CDCl}_{3}\right): \delta 7.1(\mathrm{t}, J=5.8 \mathrm{~Hz}, 1 \mathrm{H}), 6.62(\mathrm{t}, J=5.1 \mathrm{~Hz}$, $1 \mathrm{H}), 4.03(\mathrm{~s}, 1 \mathrm{H}), 3.64(\mathrm{~d}, J=11.6 \mathrm{~Hz}, 1 \mathrm{H}), 3.51(\mathrm{qd}, J=12.3,6.4 \mathrm{~Hz}, 2 \mathrm{H}), 3.38(\mathrm{qd}, J=$ $13.5,6.4 \mathrm{~Hz}, 2 \mathrm{H}), 3.23(\mathrm{~d}, J=11.7 \mathrm{~Hz}, 1 \mathrm{H}), 2.61(\mathrm{dtd}, J=8.4,6.6,1.8 \mathrm{~Hz}, 2 \mathrm{H}), 2.43(\mathrm{t}, J=$ $6.2 \mathrm{~Hz}, 2 \mathrm{H}), 1.41(\mathrm{~s}, 3 \mathrm{H}), 1.38(\mathrm{~s}, 3 \mathrm{H}), 1.36(\mathrm{t}, J=8.5 \mathrm{~Hz}, 1 \mathrm{H}), 0.98(\mathrm{~s}, 3 \mathrm{H}), 0.92(\mathrm{~s}$, 3H). ${ }^{13}$ C-NMR (101 MHz, $\left.\mathrm{CDCl}_{3}\right): \delta 171.2,170.30,99.1,77.2,71.4,42.5,36.1,35.0,33.0$, 
29.5, 24.5, 22.2, 18.9, 18.6. HRMS (FAB) calculated for $\mathrm{C}_{14} \mathrm{H}_{26} \mathrm{~N}_{2} \mathrm{O}_{4} \mathrm{~S} 319.1692$; Found $319.16924[\mathrm{M}+\mathrm{H}]^{+}$.

\section{D-[p-(Hydroxy)phenyl]glycine--s-serine-L-[p-(hydroxy)phenyl]glycyl-pantetheine (12a)}

To a $250 \mathrm{~mL}$ pressure flask, protected tripeptide 10a $(580 \mathrm{mg}, 0.75 \mathrm{mmol})$ was dissolved in $20 \mathrm{~mL}$ of reagent grade THF and to it this solution was added a catalytic amount of Pd-OH/ C. The mixture was vigorously shaken under $50 \mathrm{psi}$ of $\mathrm{H}_{2}$ overnight on a Parr hydrogenator apparatus. The mixture was filtered through Celite, which was washed with $200 \mathrm{~mL}$ of THF and concentrated in vacuo to a white foam and used in the next step without further purification.

To a $25 \mathrm{~mL}$ round-bottomed flask equipped with a magnetic stir bar, the freshly deprotected tripeptide ( $380 \mathrm{mg}, 0.75 \mathrm{mmol}$ ) was dissolved in $5 \mathrm{~mL}$ of regent grade DMF. To this solution was added $\mathrm{K}_{2} \mathrm{CO}_{3}(291 \mathrm{mg}, 2.27 \mathrm{mmol})$ and PyBOP (471 mg, $\left.0.91 \mathrm{mmol}\right)$ followed by 11 , and the reaction mixture was stirred at room temperature for $1 \mathrm{~h}$. The solution was diluted with $35 \mathrm{~mL}$ of EtOAc and washed with sat. aq. $\mathrm{NH}_{4} \mathrm{Cl}(2 \times 15 \mathrm{~mL})$, sat. aq. $\mathrm{NaHCO}_{3}(1 \times 15 \mathrm{~mL})$ and concentrated in vacuo. The residue was re-dissolved in $2.0 \mathrm{~mL}$ of 1:1 ACN: $\mathrm{H}_{2} \mathrm{O}$ and purified according to Prep Method B as a mixture of diastereomers. The product was collected, frozen on dry ice and lyophilized to dryness. The lyophilized powder was dissolved in TFA for $10 \mathrm{~min}$, concentrated in vacuo, re-dissolved in $2 \mathrm{~mL}$ of 80: 20 $\mathrm{H}_{2} \mathrm{O}$ : ACN with $0.1 \%$ TFA and purified with Prep Method B. The product was collected, frozen on dry ice and lyophilized to dryness to afford the product as the white TFA salt (205 $\mathrm{mg}, 35 \%$ ). Isolation of $2 \mathrm{mg}$ of diasteromerically pure material was achieved using Analytical Method A. ${ }^{\mathbf{1}} \mathbf{H}-\mathbf{N M R}\left(400 \mathrm{MHz} ; \mathrm{D}_{2} \mathrm{O}\right): \delta 7.24(\mathrm{~d}, J=8.8 \mathrm{~Hz}, 2 \mathrm{H}), 7.23(\mathrm{~d}, J=$ $8.8 \mathrm{~Hz}, 2 \mathrm{H}), 6.86(\mathrm{~d}, J=8.8 \mathrm{~Hz}, 2 \mathrm{H}), 6.84(\mathrm{~d}, J=8.8 \mathrm{~Hz}, 2 \mathrm{H}), 6.46(\mathrm{~s}, 1 \mathrm{H}), 5.04(\mathrm{~s}, 1 \mathrm{H})$, 4.42 (X of ABX, $J=6.4,4.8 \mathrm{~Hz}, 1 \mathrm{H}), 3.86(\mathrm{~s}, 1 \mathrm{H}), 3.74(\mathrm{AB}$ of ABX, $J=11.6,6.4,4.8 \mathrm{~Hz}$, $2 \mathrm{H}), 3.39(\mathrm{~d}, J=11.2 \mathrm{~Hz}, 1 \mathrm{H}), 3.27(\mathrm{~d}, J=11.2 \mathrm{~Hz}, 1 \mathrm{H}), 3.29-3.24(\mathrm{~m}, 4 \mathrm{H}), 2.99$ (app t, $J=$ $5.9 \mathrm{~Hz}, 2 \mathrm{H}$ ), 2.17 (app td, $J=6.6,1.8 \mathrm{~Hz}, 2 \mathrm{H}), 0.80(\mathrm{~s}, 3 \mathrm{H}), 0.76(\mathrm{~s}, 3 \mathrm{H}) .{ }^{13} \mathbf{C}-\mathbf{N M R}(101$ $\left.\mathrm{MHz}, \mathrm{D}_{2} \mathrm{O}\right): \delta 201.1,175.0,173.9,171.2,169.0,163.2,162.8,157.2,156.4,129.8,129.7$, $126.3,123.5,116.3,116.0,75.7,68.4,63.5,60.8,56.0,55.5,38.6,38.3,35.3,35.1,28.1$, 20.5, 19.1. HRMS (FAB) calculated for $\mathrm{C}_{30} \mathrm{H}_{41} \mathrm{~N}_{5} \mathrm{O}_{10} \mathrm{~S}$ 664.26524; Found 664.26512 [M $+\mathrm{H}]^{+}$.

\section{$\mathrm{D}-[p-($ Hydroxy)phenyl]glycine--serine-o-[p-(hydroxy)phenyl]glycyl-pantetheine (12b)}

The title compound was prepared and purified analogously to compound 12a by replacing 10a with $10 \mathrm{~b}(580 \mathrm{mg}, 0.75 \mathrm{mmol})$. The product was obtained as the TFA salt $(229 \mathrm{mg}$, $39 \%$ ). Isolation of $2 \mathrm{mg}$ of diasteromerically pure material was achieved using Analytical Method A. ${ }^{1}$ H-NMR $\left(400 \mathrm{MHz} ; \mathrm{D}_{2} \mathrm{O}\right): \delta 7.29(\mathrm{~d}, J=8.7 \mathrm{~Hz}, 2 \mathrm{H}), 7.23(\mathrm{~d}, J=8.7 \mathrm{~Hz}, 2 \mathrm{H})$, $6.89(\mathrm{~d}, J=8.7 \mathrm{~Hz}, 2 \mathrm{H}), 6.84(\mathrm{~d}, J=8.7 \mathrm{~Hz}, 2 \mathrm{H}), 5.46(\mathrm{~s}, 1 \mathrm{H}), 5.07(\mathrm{~s}, 1 \mathrm{H}), 4.48(\mathrm{t}, J=5.6$ $\mathrm{Hz}, 1 \mathrm{H}), 3.87(\mathrm{~s}, 1 \mathrm{H}), 3.63(\mathrm{~d}, J=5.6 \mathrm{~Hz}, 2 \mathrm{H}), 3.40(\mathrm{~d}, J=11.2 \mathrm{~Hz}, 1 \mathrm{H}), 3.30-3.26(\mathrm{~m}$, $5 \mathrm{H}), 3.04-2.97(\mathrm{~m}, 2 \mathrm{H}), 2.19(\mathrm{app} \mathrm{td}, J=6.5,2.1 \mathrm{~Hz}, 2 \mathrm{H}), 0.81(\mathrm{~s}, 3 \mathrm{H}), 0.77(\mathrm{~s}, 3 \mathrm{H}) .{ }^{13} \mathrm{C}-$ NMR $\left(101 \mathrm{MHz}, \mathrm{D}_{2} \mathrm{O}\right): \delta 201.0,175.0,173.9,171.2,169.0,157.2,156.4,129.8,129.7$, 126.3, 123.5, 123.5, 116.3, 116.0, 75.7, 68.4, 63.6, 60.8, 56.1, 55.4, 38.6, 38.3, 35.1, 28.1, 20.5, 19.1. HRMS (FAB) calculated for $\mathrm{C}_{30} \mathrm{H}_{41} \mathrm{~N}_{5} \mathrm{O}_{10} \mathrm{~S}$ 664.26524; Found 664.26484 [M $+\mathrm{H}]^{+}$.

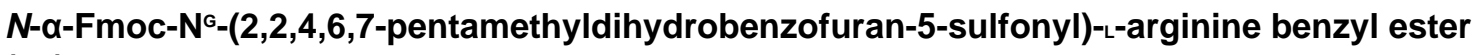

(13)

To a $500 \mathrm{~mL}$ round-bottomed flask equipped with a magnetic stir bar, Fmoc-L- $\mathrm{Arg}(\mathrm{Pbf})-\mathrm{OH}$ $(20.0 \mathrm{~g}, 30.83 \mathrm{mmol})$ was dissolved in $100 \mathrm{~mL}$ of freshly distilled DCM. To this solution was added DIEA (6.44 $\mathrm{mL}, 37.00 \mathrm{mmol})$, benzyl bromide $(4.39 \mathrm{~mL}, 36.99 \mathrm{mmol})$ and a 
catalytic amount of DMAP (376 mg, $3.08 \mathrm{mmol}$ ). The reaction mixture was stirred at room temperature for $12 \mathrm{~h}$. The solution was concentrated in vacuo and the crude product was directly purified by silica gel chromatography with 80: 20 DCM: acetone to afford the product as a white foam $(4.47 \mathrm{~g}, 20 \%) .[\mathrm{a}]_{\mathrm{D}}{ }^{25}=-0.68\left(\mathrm{c}=1.0\right.$, EtOAc); ${ }^{\mathbf{1}} \mathbf{H}-\mathbf{N M R}(400$ MHz; DMSO-d 6 ): $\delta 7.89(\mathrm{~d}, J=7.5 \mathrm{~Hz}, 2 \mathrm{H}), 7.85-7.83(\mathrm{~m}, 1 \mathrm{H}), 7.71(\mathrm{~d}, J=7.5 \mathrm{~Hz}, 2 \mathrm{H})$, 7.43-7.40 (m, 2H), 7.35-7.30 (m, 6H), 6.69 (br s, 1H), 6.45 (br s, $1 \mathrm{H}), 5.10(\mathrm{~s}, 2 \mathrm{H})$, 4.34-4.27 (m, 2H), $4.22(\mathrm{t}, J=7.0 \mathrm{~Hz}, 1 \mathrm{H}), 4.08-4.04(\mathrm{~m}, 1 \mathrm{H}), 3.36(\mathrm{~s}, 1 \mathrm{H}), 3.06-3.02(\mathrm{~m}$, 2H), $2.91(\mathrm{~s}, 2 \mathrm{H}), 2.50(\mathrm{~s}, 3 \mathrm{H}), 2.44(\mathrm{~s}, 3 \mathrm{H}), 1.99(\mathrm{~s}, 3 \mathrm{H}), 1.73(\mathrm{br} \mathrm{s}, 1 \mathrm{H}), 1.63(\mathrm{br} \mathrm{s}, 1 \mathrm{H})$, 1.45 (br s, 2H), 1.38 (s, 3H), 1.38 (s, 3H). ${ }^{13}$ C-NMR (101 MHz, DMSO-d 6 ): $\delta$ 172.1, 157.4, 156.1, 143.8, 143.7, 140.7, 137.3, 135.9, 131.4, 128.9, 128.4, 128.0, 127.7, 127.3, 127.1, 125.2, 125.2, 124.3, 121.4, 120.1, 120.0, 116.3, 109.7, 86.3, 65.9, 65.7, 53.8, 46.6, 42.5, 28.3, 19.0, 17.6, 12.3. HRMS (FAB) calculated for $\mathrm{C}_{41} \mathrm{H}_{46} \mathrm{~N}_{4} \mathrm{O}_{7} \mathrm{~S} 739.31655$; Found $739.31607[\mathrm{M}+\mathrm{H}]^{+}$.

\section{tert-Butyl---[p-(hydroxy)phenyl]glycine (14)}

To a $1 \mathrm{~L}$ Erlenmeyer flask equipped with a magnetic stir bar, $\mathrm{L}-[p$-(hydroxy)phenyl $]$ glycine (20.00 g, $119.57 \mathrm{mmol}$ ) was dissolved in $300 \mathrm{~mL}$ of $1.0 \mathrm{M} \mathrm{NaOH}$ and to this solution was added di-tert-butyl dicarbonate $(31.31 \mathrm{~g}, 143.48 \mathrm{mmol})$ in $500 \mathrm{~mL}$ of reagent grade THF. Reaction was stirred at room temperature for $12 \mathrm{~h}$. The mixture was transferred to a $1 \mathrm{~L}$ separatory funnel and the THF was partitioned with $200 \mathrm{~mL} \mathrm{Et}_{2} \mathrm{O}$ and removed. The aqueous layer was transferred to a $1 \mathrm{~L}$ Erlenmeyer flask, cooled to $0{ }^{\circ} \mathrm{C}$ with an ice-bath and acidified to $\mathrm{pH} 2.0$ with conc. $\mathrm{HCl}$. The acidified aqueous mixture was extracted with EtOAc $(3 \times 100 \mathrm{~mL})$, the organic extractions were pooled, washed with brine $(1 \times 75 \mathrm{~mL})$ and concentrated in vacuo to a viscous oil. The product was crystallized as a white solid from EtOAc/Hex $(24.92 \mathrm{~g}, 78 \%) . \mathrm{mp} 203^{\circ} \mathrm{C} ;[\mathrm{a}]_{\mathrm{D}}{ }^{24}=131.87(\mathrm{c}=1.0, \mathrm{MeOH}) .{ }^{\mathbf{1}} \mathbf{H}-\mathbf{N M R}$ (400 MHz; DMSO-d 6 ): $\delta 9.46$ (br s, 1H), 7.37 (d, $J=8.1 \mathrm{~Hz}, 1 \mathrm{H}), 7.19(\mathrm{~d}, J=8.6 \mathrm{~Hz}, 2 \mathrm{H})$, $6.73(\mathrm{~d}, J=8.6 \mathrm{~Hz}, 2 \mathrm{H}), 4.98(\mathrm{~d}, J=8.1 \mathrm{~Hz}, 1 \mathrm{H}), 1.39(\mathrm{~s}, 9 \mathrm{H}) .{ }^{\mathbf{1 3}} \mathbf{C}-\mathbf{N M R}(101 \mathrm{MHz}$, DMSO-d ${ }_{6}$ ): $\delta 172.9,157.1,155.3,129.1,127.6,115.2,78.4,57.2,28.3$. HRMS (FAB) calculated for $\mathrm{C}_{13} \mathrm{H}_{17} \mathrm{NO}_{5}$ 268.11850; Found $268.11832[\mathrm{M}+\mathrm{H}]^{+}$.

\section{N-tert-Butyloxycarbonyl---[p-(hydroxy)phenyl]glycine---arginine(Pbf) benzyl ester (15)}

To a $250 \mathrm{~mL}$ round-bottomed flask equipped with a magnetic stir bar, compound $\mathbf{1 3}$ was dissolved in $60 \mathrm{~mL}$ of freshly distilled THF. Reagent grade piperdine $(6 \mathrm{~mL})$ was added and the solution was stirred at room temperature for $30 \mathrm{~min}$. The contents of the flask were concentrated in vacuo and excess piperdine was removed by azeotropic distillation with toluene $(2 \times 100 \mathrm{~mL})$ and further dried under high vacuum to afford a white solid. After 30 min, the solid was dissolved in $15 \mathrm{~mL}$ of freshly distilled DCM and cooled to $0{ }^{\circ} \mathrm{C}$ with an ice-bath.

In a separate flask $250 \mathrm{~mL}$ round-bottomed flask, $14(1.94 \mathrm{~g}, 7.26 \mathrm{mmol})$ was dissolved in $15 \mathrm{~mL}$ of freshly distilled DCM and cooled to $0{ }^{\circ} \mathrm{C}$ in an ice-bath and DIEA $(3.16 \mathrm{~mL}$, $18.15 \mathrm{mmol}$ ) was added. When the solution was sufficiently cooled, PyBOP (3.78 g, 7.26 $\mathrm{mmol}$ ) was added and the solution containing the free-amine corresponding to compound $\mathbf{1 3}$ was transferred dropwise over $3 \mathrm{~min}$. The reaction was stirred at $0{ }^{\circ} \mathrm{C}$ to room temperature over $3 \mathrm{~h}$. The solution was concentrated in vacuoand re-dissolved in $200 \mathrm{~mL}$ of EtOAc, washed with sat. aq. $\mathrm{NH}_{4} \mathrm{Cl}(2 \times 30 \mathrm{~mL})$, sat. aq. $\mathrm{NaHCO}_{3}(2 \times 30 \mathrm{~mL})$ and $1 \times 30 \mathrm{~mL}$ brine. The organic solution was concentrated in vacuo and the product was purified by silica gel chromatography using a gradient 70: 30 EtOAc: Hex to 80: 20 EtOAc: Hex over 2 L. The desired product was isolated as a white foam $(1.99 \mathrm{~g}, 43 \%)$. $[\mathrm{a}]_{\mathrm{D}}{ }^{25}=31.8(\mathrm{c}=1.0$, EtOAc); ${ }^{1} \mathrm{H}-\mathrm{NMR}(400 \mathrm{MHz}$; DMSO-d 6 ): $\delta 9.38(\mathrm{~s}, 1 \mathrm{H}), 8.48(\mathrm{~d}, J=7.4 \mathrm{~Hz}, 1 \mathrm{H})$, 7.37-7.23 (m, 5H), 7.19 (d, $J=8.6 \mathrm{~Hz}, 2 \mathrm{H}), 7.09(\mathrm{~d}, J=8.8 \mathrm{~Hz}, 1 \mathrm{H}), 6.69$ (d, $J=8.6 \mathrm{~Hz}$, 2H), 6.45 (br s, 1H), 5.14 (d, $J=8.8 \mathrm{~Hz}, 1 \mathrm{H}), 5.03-5.01(\mathrm{~m}, 2 \mathrm{H}), 4.31(\mathrm{br} \mathrm{q}, J=6.7 \mathrm{~Hz}, 1 \mathrm{H})$, 
$3.05(\mathrm{q}, J=6.5 \mathrm{~Hz}, 2 \mathrm{H}), 2.50(\mathrm{~s}, 3 \mathrm{H}), 2.45(\mathrm{~s}, 3 \mathrm{H}), 2.01(\mathrm{~s}, 3 \mathrm{H}), 1.78-1.66(\mathrm{~m}, 1 \mathrm{H})$, 1.65-1.55 (m, $1 \mathrm{H}), 1.43(\mathrm{~s}, 3 \mathrm{H}), 1.40(\mathrm{~s}, 3 \mathrm{H}), 1.38(\mathrm{~s}, 9 \mathrm{H}) .{ }^{\mathbf{1 3}} \mathrm{C}-\mathrm{NMR}$ (101 MHz, DMSO$\left.\mathrm{d}_{6}\right): \delta 171.88,171.1,157.9,157.3,156.5,155.3,137.7,136.2,131.9,129.2,128.9,128.9$, 128.5, 128.4, 128.2, 124.8, 116.8, 115.4, 86.7, 78.8, 66.4, 57.4, 52.3, 43.0, 31.1, 28.8, 28.6, 19.5, 18.1, 12.8. HRMS (FAB) calculated for $\mathrm{C}_{39} \mathrm{H}_{51} \mathrm{~N}_{5} \mathrm{O}_{9} \mathrm{~S}$ 766.34858; Found 766.34757 $[\mathrm{M}+\mathrm{H}]^{+}$.

\section{$N$-tert-Butyloxycarbonyl---[p-(hydroxy)phenyl]glycine--arginine(Pbf)-o-[p- (benzyloxy)phenyl]glycine-ı-serine---[p-(benzyloxy)phenyl]glycine benzyl ester (16a)}

To a $250 \mathrm{~mL}$ round-bottomed flask equipped with a magnetic stir bar, compound $\mathbf{1 5}$ (1.15 g, $1.31 \mathrm{mmol}$ ) was dissolved in $30 \mathrm{~mL}$ of reagent grade THF. To this solution was added a catalytic amount of $\mathrm{Pd}-\mathrm{OH} / \mathrm{C}$ and the dipeptide was hydrogenated under $1 \mathrm{~atm}$. of $\mathrm{H}_{2}$ for 12 h. The mixture was filtered through Celite, washed with THF $(3 \times 50 \mathrm{~mL})$ and the organic filtrate was concentrated in vacuo and used in the next reaction without further purification. In a separate $250 \mathrm{~mL}$ round-bottomed flask equipped with a magnetic stir bar, tripeptide 10a $(1.11 \mathrm{~g}, 1.43 \mathrm{mmol})$ was dissolved in $60 \mathrm{~mL}$ of TFA and stirred at room temperature for 30 min. The solution was concentrated in vacuo and the solvents were removed by azeotropic distillation with toluene $(3 \times 50 \mathrm{~mL})$.

To a third $250 \mathrm{~mL}$ round-bottomed flask equipped with a magnetic stir bar, the freshly deprotected compound $\mathbf{1 5}$ was added in $30 \mathrm{~mL}$ of reagent grade DMF. To this was added DIEA ( $228 \mu \mathrm{L}, 1.31 \mathrm{mmol})$ and the solution was cooled to $0{ }^{\circ} \mathrm{C}$ in an ice-bath. The freshly deprotected peptide corresponding to compound 10a was dissolved in $20 \mathrm{~mL}$ of reagent grade DMF, DIEA ( $456 \mu \mathrm{L}, 2.62 \mathrm{mmol})$ was added and the solution was cooled to $0{ }^{\circ} \mathrm{C}$ in an ice-bath. After both solutions were sufficiently cooled, PyBOP (747 mg, $1.43 \mathrm{mmol}$ ) was added to the flask containing freshly deprotected dipeptide $\mathbf{1 5}$ and after $1 \mathrm{~min}$, freshly deblocked 10a was added dropwise over $2 \mathrm{~min}$. The reaction mixture was stirred from $0{ }^{\circ} \mathrm{C}$ to room temperature over $3 \mathrm{~h}$. The reaction mixture was diluted with $150 \mathrm{~mL}$ of EtOAc and washed with sat. aq. $\mathrm{NH}_{4} \mathrm{Cl}(2 \times 75 \mathrm{~mL})$, sat. aq. $\mathrm{NaHCO}_{3}(2 \times 75 \mathrm{~mL})$ and brine $(1 \times 75$ $\mathrm{mL}$ ). The organic solution was concentrated in vacuo and the product was purified by silica gel chromatography with 98: 2 EtOAc: $\mathrm{MeOH}$ to afford the product as a white foam (733 $\mathrm{mg}, 42 \%)$. $[\mathrm{a}]_{\mathrm{D}}{ }^{25}=-20.7(\mathrm{c}=1.0, \mathrm{MeOH}) .{ }^{1} \mathrm{H}-\mathrm{NMR}(400 \mathrm{MHz} ;$ DMSO-d 6$): \delta 9.40(\mathrm{~s}$, $1 \mathrm{H}), 8.77(\mathrm{~d}, J=7.2 \mathrm{~Hz}, 1 \mathrm{H}), 8.45(\mathrm{~d}, J=8.0 \mathrm{~Hz}, 1 \mathrm{H}), 8.42(\mathrm{~d}, J=7.6 \mathrm{~Hz}, 1 \mathrm{H}), 8.16(\mathrm{~d}, J=$ $8.0 \mathrm{~Hz}, 1 \mathrm{H}), 7.46-7.22(\mathrm{~m}, 20 \mathrm{H}), 7.18(\mathrm{~d}, J=8.8 \mathrm{~Hz}, 2 \mathrm{H}), 7.01(\mathrm{~d}, J=8.8 \mathrm{~Hz}, 2 \mathrm{H}), 6.91(\mathrm{~d}$, $J=8.8 \mathrm{~Hz}, 2 \mathrm{H}), 6.69(\mathrm{~d}, J=8.4 \mathrm{~Hz}, 2 \mathrm{H}), 6.49-6.36(\mathrm{br} \mathrm{s}, 2 \mathrm{H}), 5.51(\mathrm{~d}, J=8.0 \mathrm{~Hz}, 1 \mathrm{H}), 5.43$ $(\mathrm{d}, J=6.8 \mathrm{~Hz}, 1 \mathrm{H}), 5.13,5.10\left(\mathrm{ABq}, J_{A B} \sim 12.1 \mathrm{~Hz}, 2 \mathrm{H}\right), 5.12(\mathrm{~s}, 2 \mathrm{H}), 5.11-5.09(\mathrm{~m}, 1 \mathrm{H})$, $5.05(\mathrm{~s}, 2 \mathrm{H}), 4.82(\mathrm{t}, J=5.3 \mathrm{~Hz}, 1 \mathrm{H}), 4.43-4.37(\mathrm{~m}, 2 \mathrm{H}), 3.54-3.47(\mathrm{~m}, 2 \mathrm{H}), 3.03-3.00(\mathrm{~m}$, $2 \mathrm{H}), 2.94(\mathrm{~s}, 2 \mathrm{H}), 2.47(\mathrm{~s}, 3 \mathrm{H}), 2.42(\mathrm{~s}, 3 \mathrm{H}), 2.00(\mathrm{~s}, 3 \mathrm{H}), 1.63-1.57(\mathrm{~m}, 1 \mathrm{H}), 1.51-1.39(\mathrm{~m}$, $3 \mathrm{H}), 1.39$ (s, 6H), 1.36 (s, 9H). ${ }^{13} \mathrm{C}-\mathrm{NMR}\left(101 \mathrm{MHz}, \mathrm{DMSO}-\mathrm{d}_{6}\right)$ : $\delta 170.6,170.4,170.4$, 169.9, 169.7, 158.3, 157.7, 157.4, 156.8, 156.0, 137.3, 137.1, 137.0, 135.8, 131.4, 131.1, $129.2,129.0,128.4,128.42,128.37,128.3,128.1,128.0,128.0,127.84,127.81,127.7$, 127.6, 127.5, 124.3, 114.99, 114.88, 114.4, 86.3, 78.4, 69.2, 66.1, 61.69, 61.65, 55.8, 54.9, 45.89, 45.85, 42.5, 28.3, 28.2, 26.0, 25.9, 19.0, 17.6, 12.3. HRMS (FAB) calculated for $\mathrm{C}_{72} \mathrm{H}_{82} \mathrm{~N}_{8} \mathrm{O}_{15} \mathrm{~S}$ 1331.56986; Found 1331.57123 [M+H.

\section{N-tert-Butyloxycarbonyl---[p-(hydroxy)phenyl]glycine-L-arginine(Pbf)-o-[p- (benzyloxy)phenyl]glycine-ı-serine-o-[p-(benzyloxy)phenyl]glycine benzyl ester (16b)}

The title compound was prepared and purified analogously to compound 16a by replacing 10a with $10 b(1.17 \mathrm{~g}, 1.51 \mathrm{mmol})$. The product was obtained as a white foam $(722 \mathrm{mg}$, $36 \%) .[\mathrm{a}]_{\mathrm{D}}{ }^{23}=7.3(\mathrm{c}=1.0, \mathrm{MeOH}) .{ }^{\mathbf{1}} \mathbf{H}-\mathbf{N M R}(400 \mathrm{MHz}$; DMSO-d6): $\delta 9.39(\mathrm{~s}, 1 \mathrm{H}), 8.79$ $(\mathrm{d}, J=7.4 \mathrm{~Hz}, 1 \mathrm{H}), 8.45(\mathrm{~d}, J=7.6 \mathrm{~Hz}, 1 \mathrm{H}), 8.39(\mathrm{~d}, J=7.7 \mathrm{~Hz}, 1 \mathrm{H}), 8.18(\mathrm{~d}, J=7.8 \mathrm{~Hz}$, 1H), 7.45-7.18 (m, 20 H), $7.19(\mathrm{~d}, J=8.7 \mathrm{~Hz}, 2 \mathrm{H}), 7.00(\mathrm{~d}, J=8.8 \mathrm{~Hz}, 2 \mathrm{H}), 6.92(\mathrm{~d}, J=8.8$ 
$\mathrm{Hz}, 2 \mathrm{H}), 6.70(\mathrm{~d}, J=8.6 \mathrm{~Hz}, 2 \mathrm{H}), 6.40(\mathrm{br} \mathrm{s}, 2 \mathrm{H}), 5.54(\mathrm{~d}, J=7.7 \mathrm{~Hz}, 1 \mathrm{H}), 5.46(\mathrm{~d}, J=7.2$ $\mathrm{Hz}, 1 \mathrm{H}), 5.17-5.06(\mathrm{~m}, 7 \mathrm{H}), 4.85(\mathrm{t}, J=6.6 \mathrm{~Hz}, 1 \mathrm{H}), 4.52-4.02(\mathrm{~m}, 2 \mathrm{H}), 3.46-3.38(\mathrm{~m}, 2 \mathrm{H})$, 3.04-2.99 (m, 2H), 2.94 (s, 2H), 2.49 (s, 3H), 2.43 (s, 3H), $2.00(\mathrm{~s}, 3 \mathrm{H}), 1.62-1.60(\mathrm{~m}, 1 \mathrm{H})$, 1.50-1.41 (m, 3H), $1.40(\mathrm{~s}, 6 \mathrm{H}), 1.37(\mathrm{~s}, 9 \mathrm{H}) .{ }^{\mathbf{1 3}} \mathbf{C}-\mathrm{NMR}\left(101 \mathrm{MHz}, \mathrm{DMSO}-\mathrm{d}_{6}\right): \delta 170.62$, $170.55,170.5,170.4,169.8,169.7,158.2,157.8,157.7,157.4,156.8,156.0,137.3,137.1$, $137.0,135.7,131.4,128.94,128.91,128.5,128.43,128.36,128.2,127.99,127.98,127.9$, $127.8,127.68,127.65,127.6,127.5,124.3,116.3,115.0,114.9,114.9,114.8,114.5,114.4$, 86.3, 69.21, 69.19, 66.2, 61.8, 42.5, 30.7, 28.3, 28.2, 19.0, 17.6, 12.3. HRMS (FAB) calculated for $\mathrm{C}_{72} \mathrm{H}_{82} \mathrm{~N}_{8} \mathrm{O}_{15} \mathrm{~S}$ 1353.55181; Found $1353.5527[\mathrm{M}+\mathrm{Na}]^{+}$.

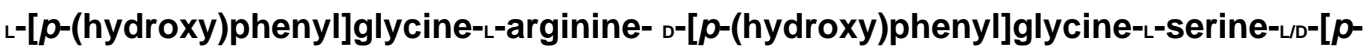 (hydroxy)phenyl]glycyl-pantetheine (17a/17b)}

To a $250 \mathrm{~mL}$ pressure flask, protected peptide $\mathbf{1 6}$ a or $\mathbf{1 6 b}(213 \mathrm{mg}, 0.16 \mathrm{mmol})$ was dissolved in $10 \mathrm{~mL}$ of reagent grade THF and to the solution was added a catalytic amount of Pd-OH/C and the flask was vigorously shaken under $50 \mathrm{psi}$ of $\mathrm{H}_{2}$ for $12 \mathrm{~h}$. The contents of the flask were filtered through Celite, washed with $100 \mathrm{~mL}$ of THF and concentrated in vacuo to a white foam, which was used without further purification.

To a $25 \mathrm{~mL}$ round-bottomed flask, equipped with a magnetic stir bar, the freshly deprotected pentapeptide was dissolved in $5 \mathrm{~mL}$ of regent grade DMF. To this solution was added DIEA $(84 \mu \mathrm{L}, 0.48 \mathrm{mmol})$ and PyBOP (100 mg, $0.19 \mathrm{mmol})$ followed by $11(61 \mathrm{mg}, 0.19 \mathrm{mmol})$. The reaction was stirred at room temperature for $1 \mathrm{~h}$. The solution was diluted with $50 \mathrm{~mL}$ of EtOAc, washed with sat. aq. $\mathrm{NH}_{4} \mathrm{Cl}(2 \times 15 \mathrm{~mL})$, sat. aq. $\mathrm{NaHCO}_{3}(1 \times 15 \mathrm{~mL})$ and concentrated in vacuo. The residue was re-dissolved in $2.0 \mathrm{~mL}$ of $1: 1 \mathrm{ACN}: \mathrm{H}_{2} \mathrm{O}$ solution and purified according to Prep Method B as a mixture of diastereomers. The product was collected, frozen on dry ice and lyophilized to dryness. The lyophilized powder was dissolved in TFA for $10 \mathrm{~min}$, concentrated in vacuo, redissolved in $2 \mathrm{~mL}$ of $80: 20 \mathrm{H}_{2} \mathrm{O}$ : ACN supplemented with $0.1 \%$ TFA and purified using Prep Method B. Product 17a/17b product was collected, frozen on dry ice, lyophilized to dryness and obtained as the white TFA salt $(60.8 \mathrm{mg}, 35 \%)$. The product was further purified using Analytical Method A and verified to be an inseparable mixture of diastereomers. ${ }^{1} \mathrm{H}-\mathrm{NMR}(\mathbf{1 7 a})\left(400 \mathrm{MHz} ; \mathrm{D}_{2} \mathrm{O}\right): \delta$ $7.24(\mathrm{~d}, J=8.8 \mathrm{~Hz}, 2 \mathrm{H}), 7.21(\mathrm{~d}, J=8.6 \mathrm{~Hz}, 2 \mathrm{H}), 7.11(\mathrm{~d}, J=8.8 \mathrm{~Hz}, 2 \mathrm{H}), 6.85(\mathrm{~d}, J=8.4$ $\mathrm{Hz}, 2 \mathrm{H}), 6.81(\mathrm{~d}, J=8.8 \mathrm{~Hz}, 2 \mathrm{H}), 6.76(\mathrm{~d}, J=8.4 \mathrm{~Hz}, 2 \mathrm{H}), 5.50(\mathrm{~s}, 1 \mathrm{H}), 5.29(\mathrm{~s}, 1 \mathrm{H}), 5.05$ $(\mathrm{s}, 1 \mathrm{H}), 4.44(\mathrm{t}, J=5.5 \mathrm{~Hz}, 1 \mathrm{H}), 4.32-4.29(\mathrm{~m}, 1 \mathrm{H}), 3.91(\mathrm{~s}, 1 \mathrm{H}), 3.82-3.80(\mathrm{~m}, 2 \mathrm{H}), 3.44(\mathrm{~d}$, $J=11.2 \mathrm{~Hz}, 1 \mathrm{H}), 3.34-3.27(\mathrm{~m}, 4 \mathrm{H}), 3.33(\mathrm{~d}, J=11.2 \mathrm{~Hz}), 3.06-2.99(\mathrm{~m}, 4 \mathrm{H}), 2.26-2.22(\mathrm{~m}$, 2H), 1.70-1.64 (m, 2H), 1. 49-1.40 (m, 2H), 0.85 (s, 3H), 0.81 (s, 3H). ${ }^{\mathbf{H}} \mathbf{H}-\mathbf{N M R}(\mathbf{1 7 b})(400$ $\left.\mathrm{MHz} ; \mathrm{D}_{2} \mathrm{O}\right): \delta 7.30(\mathrm{~d}, J=8.4 \mathrm{~Hz}, 2 \mathrm{H}), 7.26(\mathrm{~d}, J=8.8 \mathrm{~Hz}, 2 \mathrm{H}), 7.16(\mathrm{~d}, J=8.7 \mathrm{~Hz}, 2 \mathrm{H})$, $6.90(\mathrm{~d}, J=8.6 \mathrm{~Hz}, 2 \mathrm{H}), 6.81(\mathrm{~d}, J=8.7 \mathrm{~Hz}, 2 \mathrm{H}), 6.76(\mathrm{~d}, J=8.6 \mathrm{~Hz}, 2 \mathrm{H}), 5.45(\mathrm{~s}, 1 \mathrm{H})$, $5.28(\mathrm{~s}, 1 \mathrm{H}), 5.03(\mathrm{~s}, 1 \mathrm{H}), 4.44(\mathrm{t}, J=5.5 \mathrm{~Hz}, 1 \mathrm{H}), 4.32-4.29(\mathrm{~m}, 1 \mathrm{H}), 3.91(\mathrm{~s}, 1 \mathrm{H}), 3.79-3.78$ $(\mathrm{m}, 2 \mathrm{H}), 3.44(\mathrm{~d}, J=11.2 \mathrm{~Hz}, 1 \mathrm{H}), 3.34-3.27(\mathrm{~m}, 4 \mathrm{H}), 3.33(\mathrm{~d}, J=11.2 \mathrm{~Hz}), 3.06-2.99(\mathrm{~m}$, $4 \mathrm{H}), 2.24(\mathrm{~J}=6.0,2 \mathrm{H}), 1.70-1.64(\mathrm{~m}, 2 \mathrm{H}), 1.49-1.40(\mathrm{~m}, 2 \mathrm{H}), 0.85(\mathrm{~s}, 3 \mathrm{H}), 0.81(\mathrm{~s}$, 3H). ${ }^{13}$ C-NMR (17a/17b) $\left(101 \mathrm{MHz}, \mathrm{D}_{2} \mathrm{O}\right): \delta 201.0,175.0,173.9,172.6,172.1,171.4$, $168.9,168.8,163.5,163.1,162.8,162.4,157.3,156.6,156.4,156.3,156.1,129.7,129.7$, 129.6, 129.6, 129.3, 129.2, 129.2, 127.1, 126.4, 123.2, 123.2, 117.8, 116.3, 115.98, 115.95, 114.9, 75.8, 68.4, 63.6, 63.5, 63.4, 60.8, 57.5, 57.2, 55.9, 55.6, 54.0, 40.5, 40.4, 38.6, 38.4, 35.3, 35.2, 28.1, 27.7, 24.3, 20.5, 19.1. HRMS (FAB) calculated for $\mathrm{C}_{44} \mathrm{H}_{60} \mathrm{~N}_{10} \mathrm{O}_{13} \mathrm{~S}$ 969.41403; Found $969.41241[\mathrm{M}+\mathrm{H}]^{+}$.

\section{N-tert-Butyloxycarbonyl-o-[p-(benzyloxy)phenyl]glycine---tert-butylphosphoserine---benzyl- [p-(benzyloxy)phenyl]glycine benzyl ester (18a)}

To a $100 \mathrm{~mL}$ flame-dried round-bottomed flask, equipped with a magnetic stir bar and an argon inlet, protected tripeptide 10a $(2.10 \mathrm{~g}, 2.71 \mathrm{mmol})$ was dissolved in $15 \mathrm{~mL}$ of freshly 
distilled THF. To this solution was added tetrazole (7.22 mL, 0.45 $\mathrm{M}$ in ACN, $3.25 \mathrm{mmol}$ ) followed by di-tert-butyl $N, N$-diisopropylphosphoramidite $(1.03 \mathrm{~mL}, 3.25 \mathrm{mmol})$. The reaction mixture was allowed to stir at room temperature for $12 \mathrm{~h}$. The solution was cooled to $0{ }^{\circ} \mathrm{C}$ in an ice-bath, tert-butyl hydroperoxide $(590 \mu \mathrm{L}, 5.5 \mathrm{M}$ in decane, $3.25 \mathrm{mmol})$ was added and the reaction was stirred at $0{ }^{\circ} \mathrm{C}$ for $3 \mathrm{~h}$. The solution was diluted with $150 \mathrm{~mL}$ of EtOAc and washed with 1: 1 sat. aq. $\mathrm{NaHCO}_{3}: \mathrm{NaS}_{2} \mathrm{O}_{3}(2 \times 50 \mathrm{~mL})$. The EtOAc was concentrated in vacuo to a viscous yellow oil, which was purified by flash chromatography on silica gel that was pre-treated for $12 \mathrm{~h}$ with 1:1 solution of EtOAc: Hex containing 5\% triethylamine. The product was eluted with a step gradient mobile phase of 70: 30 Hex: EtOAc to 50: 50 Hex: EtOAc to elute the partially purified product as a colorless oil containing phosphoramidite impurities. Crystallization of the oil in $\mathrm{Et}_{2} \mathrm{O}$ and $\mathrm{Hex}$ provided the desired product as a white granular solid $(1.67 \mathrm{~g}, 64 \%) \cdot \mathrm{mp} 84{ }^{\circ} \mathrm{C} ;[\mathrm{a}]_{\mathrm{D}}{ }^{24}=-3.2(\mathrm{c}=$ 1.0, EtOAc). ${ }^{1} \mathbf{H}-\mathbf{N M R}\left(400 \mathrm{MHz} ; \mathrm{CDCl}_{3}\right): \delta 7.76$ (br s, $\left.1 \mathrm{H}\right), 7.68$ (br s, $\left.1 \mathrm{H}\right), 7.43-7.21$ (m, $20 \mathrm{H}), 6.94(\mathrm{~d}, J=8.8,2 \mathrm{H}), 6.93(\mathrm{~d}, J=8.8,2 \mathrm{H}), 5.63(\mathrm{~d}, J=6.0 \mathrm{~Hz}, 1 \mathrm{H}), 5.57(\mathrm{~d}, J=6.8$ $\mathrm{Hz}, 1 \mathrm{H}), 5.16(\mathrm{~s}, 1 \mathrm{H}), 5.15(\mathrm{~s}, 1 \mathrm{H}), 5.06(\mathrm{~s}, 2 \mathrm{H}), 5.5(\mathrm{~s}, 2 \mathrm{H}), 4.69-4.66(\mathrm{~m}, 1 \mathrm{H}), 4.42$ (br t, $J$ $=8.8 \mathrm{~Hz}, 1 \mathrm{H}), 3.96(\mathrm{td}, J=10.1,3.7 \mathrm{~Hz}, 1 \mathrm{H}), 1.41(\mathrm{~s}, 9 \mathrm{H}), 1.40(\mathrm{~s}, 9 \mathrm{H}), 1.37(\mathrm{~s}, 9 \mathrm{H}) .{ }^{13} \mathrm{C}-$ NMR (101 MHz, $\left.\mathrm{CDCl}_{3}\right): \delta 171.3,171.3,170.2,168.3,159.0,136.9,135.5,129.0,128.7$, 128.60, 128.56, 128.3, 128.2, 128.0, 128.0, 127.6, 127.6, 115.4, 115.2, 100.1, 83.8, 83.7, 83.5, 83.4, 70.1, 67.3, 65.8, 56.4, 53.7, 53.6. 31P-NMR (162 $\left.{ }^{3 H z}, \mathrm{CDCl}_{3}\right): \delta-8.92 . \mathbf{H R M S}$ (FAB) calculated for $\mathrm{C}_{53} \mathrm{H}_{64} \mathrm{~N}_{3} \mathrm{O}_{12} \mathrm{P}$ 966.43059; Found $966.42975[\mathrm{M}+\mathrm{H}]^{+}$.

\section{$N$-tert-Butyloxycarbonyl-o-[p-(benzyloxy)phenyl]glycine--t-tert- butylphosphoserine-o-[p- (benzyloxy)phenyl]glycine benzyl ester (18b)}

The title compound was prepared and purified analogously to compound $\mathbf{1 8 a}$ by replacing 10a with 10b $(1.41 \mathrm{~g}, 1.82 \mathrm{mmol})$. The product was obtained as a white foam $(1.09 \mathrm{~g}, 62 \%)$. $\operatorname{mp~} 83{ }^{\circ} \mathrm{C} ;[\mathrm{a}]_{\mathrm{D}}{ }^{24}=-49.7(\mathrm{c}=1.0, \mathrm{EtOAc}) .{ }^{\mathbf{1}} \mathbf{H}-\mathbf{N M R}\left(400 \mathrm{MHz} ; \mathrm{CDCl}_{3}\right): \delta 7.81(\mathrm{br} \mathrm{s}, 2 \mathrm{H})$, 7.44-7.22 (m, 20H), $6.94(\mathrm{~d}, J=8.4 \mathrm{~Hz}, 2 \mathrm{H}), 6.92(\mathrm{~d}, J=8.4 \mathrm{~Hz}, 2 \mathrm{H}), 5.55(\mathrm{~d}, J=7.1 \mathrm{~Hz}$, $1 \mathrm{H}), 5.53(\mathrm{br} \mathrm{s}, 1 \mathrm{H}), 5.19,5.14\left(\mathrm{ABq}, J_{A B}=12.4 \mathrm{~Hz}, 2 \mathrm{H}\right) 5.05(2 \times \mathrm{s}, 4 \mathrm{H}), 4.70-4.66(\mathrm{~m}$, $1 \mathrm{H}), 4.43$ (br t, $J=10.2 \mathrm{~Hz}, 1 \mathrm{H}), 3.92$ (br dt, $J=9.2,4.5 \mathrm{~Hz}, 1 \mathrm{H}), 1.44$ (s, 9H), 1.37 (s, 18H). ${ }^{13}$ C-NMR $\left(101 \mathrm{MHz}, \mathrm{CDCl}_{3}\right): \delta 171.32,171.31,170.26,168.3,159.02,158.96$, 137.0, 136.9, 135.5, 128.8, 128.7, 128.6, 128.4, 128.2, 128.14, 128.12, 128.07, 127.6, 115.4, $115.2,83.9,83.8,83.5,70.13,70.11,67.3,65.8,56.5,53.6,53.6,29.9,29.8,29.8,28.4 .{ }^{31} \mathbf{P}-$ NMR $\left(162 \mathrm{MHz}, \mathrm{CDCl}_{3}\right): \delta-8.85$. HRMS (FAB) calculated for $\mathrm{C}_{53} \mathrm{H}_{64} \mathrm{~N}_{3} \mathrm{O}_{12} \mathrm{P} 966.43059$; Found $966.43025[\mathrm{M}+\mathrm{H}]^{+}$.

\section{D-[p-(hydroxy)phenyl]glycine---phosphoserine---[p-(hydroxy)phenyl] glycyl-pantetheine $(19 a / 19 b)$}

To a $250 \mathrm{~mL}$ pressure flask, protected peptide $\mathbf{1 8 a}$ or $\mathbf{1 8 b}(77 \mathrm{mg}, 0.10 \mathrm{mmol})$ was dissolved in $10 \mathrm{~mL}$ of reagent grade $\mathrm{THF}$ and to it was added a catalytic amount of $\mathrm{Pd}-\mathrm{OH} / \mathrm{C}$ and the flask was vigorously shaken under $50 \mathrm{psi}$ of $\mathrm{H}_{2}$ for $12 \mathrm{~h}$ on a Parr hydrogenation apparatus. The mixture was filtered through Celite, washed with $100 \mathrm{~mL}$ of THF, concentrated in vacuo to a white foam and used without further purification.

To a $10 \mathrm{~mL}$ round-bottomed flask equipped with a magnetic stir bar, freshly hydrogenolyzed tripeptide corresponding to compounds $\mathbf{1 8 a}$ or $\mathbf{1 8 b}(50.35 \mathrm{mg}, 0.10 \mathrm{mmol})$ was dissolved in $2 \mathrm{~mL}$ of reagent grade DMF and to this solution was added $\mathrm{K}_{2} \mathrm{CO}_{3}(42 \mathrm{mg}, 0.30 \mathrm{mmol})$ and cooled to $0{ }^{\circ} \mathrm{C}$ with an ice-bath. To this cooled solution was added PyBOP (63 mg, 0.12 $\mathrm{mmol}$ ) and 11 (39 $\mathrm{mg}, 0.12 \mathrm{mmol}$ ) and the reaction mixture was stirred for $30 \mathrm{~min}$ at room temperature. The solution was diluted with $50 \mathrm{~mL}$ of EtOAc and washed with sat. aq. $\mathrm{NH}_{4} \mathrm{Cl}(2 \times 20 \mathrm{~mL})$, sat. aq. $\mathrm{NaHCO}_{3}(1 \times 20 \mathrm{~mL})$ and brine $(1 \times 20 \mathrm{~mL})$. The EtOAc extract was concentrated in vacuo to a viscous oil, which was re-dissolved in $2 \mathrm{~mL} 70: 30$ ACN: $\mathrm{H}_{2} \mathrm{O}$. The product was purified by Prep Method B, collected on dry ice and 
lyophilized to dryness. The freshly lyophilized product was dissolved in $5 \mathrm{~mL}$ of reagent grade TFA and stirred at room temperature for $15 \mathrm{~min}$. The TFA was removed in vacuo and the residue was re-suspended in $2 \mathrm{~mL}$ of $70: 30 \mathrm{H}_{2} \mathrm{O}$ : ACN supplemented with $0.1 \%$ TFA. The reaction mixture was purified by Prep Method A, collected, frozen on dry ice and lyophilized to dryness as a white TFA salt $(23.0 \mathrm{mg}, 25 \%)$. The product was further purified using Analytical Method A and verified to be an inseparable mixture of diastereomers. ${ }^{1} \mathbf{H}$ NMR (19a) $\left(400 \mathrm{MHz} ; \mathrm{D}_{2} \mathrm{O}\right): \delta 7.31(\mathrm{~d}, J=8.7 \mathrm{~Hz}, 2 \mathrm{H}), 7.23(\mathrm{~d}, J=8.6 \mathrm{~Hz}, 2 \mathrm{H}), 6.89(\mathrm{~d}, J$ $=8.8 \mathrm{~Hz}, 2 \mathrm{H}), 6.84(\mathrm{~d}, J=8.7 \mathrm{~Hz}, 2 \mathrm{H}), 5.45(\mathrm{~s}, 1 \mathrm{H}), 5.08(\mathrm{~s}, 1 \mathrm{H}), 4.57(\mathrm{t}, J=5.4 \mathrm{~Hz}, 1 \mathrm{H})$, 3.97-3.89 (m, 2H), $3.41(\mathrm{~d}, J=11.3 \mathrm{~Hz}, 1 \mathrm{H}), 3.30-3.25(\mathrm{~m}, 5 \mathrm{H}), 3.05-2.98(\mathrm{~m}, 2 \mathrm{H}), 2.18$ (app td, $J=6.6,2.6 \mathrm{~Hz}, 2 \mathrm{H}), 0.81(\mathrm{~s}, 3 \mathrm{H}), 0.77$ (s, 3H). ${ }^{\mathbf{1}} \mathrm{H}-\mathbf{N M R}(\mathbf{1 9 b})\left(400 \mathrm{MHz} ; \mathrm{D}_{2} \mathrm{O}\right): \delta$ $7.31(\mathrm{~d}, J=8.7 \mathrm{~Hz}, 2 \mathrm{H}), 7.25(\mathrm{~d}, J=8.5 \mathrm{~Hz}, 2 \mathrm{H}), 6.86(\mathrm{~d}, J=8.7 \mathrm{~Hz}, 2 \mathrm{H}), 6.82(\mathrm{~d}, J=8.9$ $\mathrm{Hz}, 2 \mathrm{H}), 5.46(\mathrm{~s}, 1 \mathrm{H}), 5.06(\mathrm{~s}, 1 \mathrm{H}), 4.51(\mathrm{t}, J=5.2 \mathrm{~Hz}, 1 \mathrm{H}), 4.05(\mathrm{t}, J=6.1 \mathrm{~Hz}, 1 \mathrm{H})$, 3.97-3.89 (m, 1H), $3.40(\mathrm{~d}, J=11.3 \mathrm{~Hz}, 1 \mathrm{H}), 3.30-3.25(\mathrm{~m}, 5 \mathrm{H}), 3.05-2.98(\mathrm{~m}, 2 \mathrm{H}), 2.18$ (app td, $J=6.6,2.6 \mathrm{~Hz}, 2 \mathrm{H}), 0.81$ (s, 3H), 0.77 (s, 3H). ${ }^{\mathbf{1 3}} \mathbf{C}-\mathbf{N M R}(\mathbf{1 9 a} / \mathbf{1 9 b})(101 \mathrm{MHz}$, $\left.\mathrm{D}_{2} \mathrm{O}\right): \delta 201.4,200.9,175.0,173.9,170.6,168.9,163.1,162.8,157.2,156.4,130.0,129.8$, $129.7,126.23,126.18,123.4,123.3,116.4,116.0,75.7,68.4,63.9,63.7,56.1,56.0,54.2$, 38.6, 38.4, 35.3, 35.1, 28.1, 20.5, 19.1. ${ }^{31} \mathbf{P}-\mathbf{N M R}(19 \mathrm{a})\left(162 \mathrm{MHz} ; \mathrm{D}_{2} \mathrm{O}\right): \delta-0.04 .{ }^{31} \mathbf{P}-$ NMR (19b) $\left(162 \mathrm{MHz} ; \mathrm{D}_{2} \mathrm{O}\right): \delta-0.074$. HRMS (FAB) calculated for $\mathrm{C}_{30} \mathrm{H}_{42} \mathrm{~N}_{5} \mathrm{O}_{13}$ PS 744.23157 Found $744.23037[\mathrm{M}+\mathrm{H}]^{+}$.

\section{N-tert-Butyloxycarbonyl---acetylserine---[p-(benzyloxy)phenyl]glycine benzyl ester (20a)}

To a flame dried $250 \mathrm{~mL}$ round-bottomed flask equipped with a magnetic stir bar and an argon inlet, protected tripeptide 10a $(4.00 \mathrm{~g}, 5.17 \mathrm{mmol})$ was dissolved in $40 \mathrm{~mL}$ of reagent grade pyridine and to this was added acetic anhydride $(537 \mu \mathrm{L}, 5.69 \mathrm{mmol})$ and the reaction was stirred at room temperature for $12 \mathrm{~h}$. The reaction mixture was concentrated in vacuo to a yellow solid, which was purified by silica gel flash chromatography utilizing an isocratic mobile phase 70: 30 Hex: EtOAc to afford the product as a white solid $(4.18 \mathrm{~g}, 99 \%)$. [a $]_{\mathrm{D}}^{23}$ $=-4.4\left(\mathrm{c}=1.0\right.$, EtOAc). ${ }^{\mathbf{1}} \mathbf{H}-\mathbf{N M R}\left(400 \mathrm{MHz} ;\right.$ DMSO-d $\left._{6}\right): \delta 8.88(\mathrm{~d}, J=6.3 \mathrm{~Hz}, 1 \mathrm{H}), 8.48$ $(\mathrm{d}, J=8.0 \mathrm{~Hz}, 1 \mathrm{H}), 7.45-7.21(\mathrm{~m}, 20 \mathrm{H}), 7.02(\mathrm{~d}, J=8.6 \mathrm{~Hz}, 2 \mathrm{H}), 6.94(\mathrm{~d}, J=8.6 \mathrm{~Hz}, 2 \mathrm{H})$, $5.41(\mathrm{~d}, J=6.4 \mathrm{~Hz}, 1 \mathrm{H}), 5.21(\mathrm{~d}, J=7.7 \mathrm{~Hz}, 1 \mathrm{H}), 5.16-5.08(2 \times \mathrm{s}+\mathrm{ABq}, 6 \mathrm{H}), 4.70(\mathrm{br}$ q, $J=7.0 \mathrm{~Hz}, 1 \mathrm{H}), 4.09-4.04(\mathrm{~m}, 2 \mathrm{H}), 1.78$ (s, 3H), 1.36 (s, 9H). ${ }^{\mathbf{1 3}} \mathbf{C}-\mathbf{N M R}(101 \mathrm{MHz}$, DMSO-d $\left.{ }_{6}\right): \delta 170.6,170.2,169.9,168.5,158.4,157.7,154.8,137.1,137.0,135.7,130.9$, 129.2, 128.5, 128.4, 128.4, 128.4, 128.0, 127.9, 127.8, 127.62, 127.59, 127.5, 114.9, 114.4, 78.4, 69.2, 69.1, 66.2, 63.2, 56.9, 56.0, 51.1, 28.2, 20.3. HRMS (FAB) calculated for $\mathrm{C}_{47} \mathrm{H}_{49} \mathrm{~N}_{3} \mathrm{O}_{10} 816.34620$; Found $816.34819[\mathrm{M}+\mathrm{H}]^{+}$.

\section{N-tert-Butyloxycarbonyl---acetylserine-o-benzyl-[p-(benzyloxy)phenyl]glycine (20b)}

The title compound was prepared and purified analogously to compound $20 \mathrm{a}$ by replacing 10a with 10b (4.00 g, $5.17 \mathrm{mmol})$. The product was obtained as a white solid $(4.18 \mathrm{~g}, 99 \%)$. $[\mathrm{a}]_{\mathrm{D}}{ }^{23}=-51.3\left(\mathrm{c}=1.0\right.$, EtOAc). ${ }^{\mathbf{1}} \mathbf{H}-\mathbf{N M R}\left(400 \mathrm{MHz} ; \mathrm{DMSO}_{6}\right): \delta 8.93(\mathrm{~d}, J=6.6 \mathrm{~Hz}, 1$ $\mathrm{H}), 8.47(\mathrm{~d}, J=8.3 \mathrm{~Hz}, 1 \mathrm{H}), 7.46-7.23(\mathrm{~m}, 20 \mathrm{H}), 7.01(\mathrm{~d}, J=8.8 \mathrm{~Hz}, 2 \mathrm{H}), 6.93(\mathrm{~d}, J=8.8$ $\mathrm{Hz}, 2 \mathrm{H}), 5.44(\mathrm{~d}, J=7.1 \mathrm{~Hz}, 1 \mathrm{H}), 5.24(\mathrm{~d}, J=7.9 \mathrm{~Hz}, 1 \mathrm{H}), 5.16,5.13\left(\mathrm{ABq}, J_{A B}=12.7\right.$ $\mathrm{Hz}, 2 \mathrm{H}), 5.11$ (s, 2H), 5.08 (s, 2H), 4.72 (br q, J = 6.3 Hz, $1 \mathrm{H}), 4.073 .96$ (sym m, 2H), 1.73 (s, 3H), 1.36 (s, 9H). ${ }^{13}$ C-NMR (101 MHz, DMSO-d 6 ): $\delta 171.1,170.7,170.3,168.9,158.8$, 158.2, 137.6, 137.4, 136.2, 131.3, 129.4, 128.91, 128.89, 128.8, 128.5, 128.3, 128.3, 128.1, 128.1, 128.0, 115.4, 114.9, 69.7, 69.6, 66.7, 56.3, 51.7, 28.6, 20.7. HRMS (FAB) calculated for $\mathrm{C}_{47} \mathrm{H}_{49} \mathrm{~N}_{3} \mathrm{O}_{10} 816.34620$; Found $816.34773[\mathrm{M}+\mathrm{H}]^{+}$.

\section{$\mathrm{D}-[p$-(hydroxy)phenyl]glycine---acetylserine---[p-(hydroxy)phenyl]glycylpantetheine (21a)}

To a $250 \mathrm{~mL}$ pressure flask, protected peptide $\mathbf{2 0 a}(147 \mathrm{mg}, 0.18 \mathrm{mmol})$ was dissolved in 10 $\mathrm{mL}$ of reagent grade THF and to it was added a catalytic amount of $\mathrm{Pd}-\mathrm{OH} / \mathrm{C}$ and the 
mixture was vigorously shaken under $50 \mathrm{psi}$ of $\mathrm{H}_{2}$ for $12 \mathrm{~h}$ on a Parr hydrogenator. The contents of the flask were filtered through Celite, washed with $100 \mathrm{~mL}$ of THF and concentrated in vacuo to a white foam and used without further purification.

To a $10 \mathrm{~mL}$ round-bottomed equipped with a magnetic stir bar, 20a (100 $\mathrm{mg}, 0.18 \mathrm{mmol})$ was dissolved in $2 \mathrm{~mL}$ of reagent grade DMF and to this solution was added $\mathrm{K}_{2} \mathrm{CO}_{3}(76 \mathrm{mg}$, $0.55 \mathrm{mmol}$ ) and cooled to $0{ }^{\circ} \mathrm{C}$ in an ice-bath. To this cooled solution was added PyBOP $(114 \mathrm{mg}, 0.20 \mathrm{mmol})$ followed by $11(70 \mathrm{mg}, 0.20 \mathrm{mmol})$ and the reaction was then stirred for $30 \mathrm{~min}$ at room temperature. The solution was diluted with $50 \mathrm{~mL}$ of EtOAc and washed with sat. aq. $\mathrm{NH}_{4} \mathrm{Cl}(2 \times 20 \mathrm{~mL})$, sat. aq. $\mathrm{NaHCO}_{3}(1 \times 20 \mathrm{~mL})$ and brine $(1 \times 20 \mathrm{~mL})$. The EtOAc was concentrated in vacuo to a viscous oil, which was re-dissolved in $2 \mathrm{~mL} 70: 30$ ACN: $\mathrm{H}_{2} \mathrm{O}$. The reaction was purified by Prep Method A, collected, and frozen on dry ice and lyophilized to dryness. The product was dissolved in $5 \mathrm{~mL}$ of reagent grade TFA and stirred at room temperature for $15 \mathrm{~min}$. The TFA was removed in vacuo and the residue was re-suspended in $2 \mathrm{~mL}$ of 70: $30 \mathrm{H}_{2} \mathrm{O}$ : ACN supplemented with $0.1 \%$ TFA. The freshly deprotected product purified by Prep Method A, collected, frozen on dry ice and lyophilized to dryness to afford the product as a white TFA salt $(63.0 \mathrm{mg}, 38 \%)$. Isolation of $2 \mathrm{mg}$ of diasteromerically pure material was achieved using Analytical Method A. ${ }^{\mathbf{1}} \mathbf{H}-\mathbf{N M R}$ (400 $\left.\mathrm{MHz} ; \mathrm{D}_{2} \mathrm{O}\right): \delta 7.25(2 \times \mathrm{d}, J=8.2 \mathrm{~Hz}, 4 \mathrm{H}), 6.86(2 \times \mathrm{d}, J=8.2 \mathrm{~Hz}, 4 \mathrm{H}), 5.47(\mathrm{~s}, 1 \mathrm{H}), 5.04$ (s, $1 \mathrm{H}), 4.26(\mathrm{~d}, J=5.1 \mathrm{~Hz}, 2 \mathrm{H}), 3.87(\mathrm{~s}, 1 \mathrm{H}), 3.40(\mathrm{~d}, J=11.3 \mathrm{~Hz}, 1 \mathrm{H}), 3.29-3.24(\mathrm{~m}, 5 \mathrm{H})$, 3.00 (br t, $J \sim 6.1 \mathrm{~Hz}, 2 \mathrm{H}$ ), 2.19 (br t, $J \sim 6.4 \mathrm{~Hz}, 2 \mathrm{H}$ ), 1.82 (s, 3H), 0.80 (s, 3H), 0.77 (s, 3H). ${ }^{13}$ C-NMR $\left(101 \mathrm{MHz}, \mathrm{D}_{2} \mathrm{O}\right): \delta 200.9,188.6,175.0,173.8,173.3,169.9,168.9,166.9$, 157.2, 156.4, 155.4, 129.7, 126.1, 123.5, 117.8, 116.3, 116.0, 83.9, 75.7, 68.4, 63.6, 63.0, 55.9, 52.4, 38.6, 38.3, 35.3, 35.1, 28.1, 20.5, 19.9, 19.1. HRMS (FAB) calculated for $\mathrm{C}_{32} \mathrm{H}_{43} \mathrm{~N}_{5} \mathrm{O}_{11} \mathrm{~S}$ 706.27580; Found $706.27413[\mathrm{M}+\mathrm{H}]^{+}$.

\section{D-[p-(hydroxy)phenyl]glycine---acetylserine-o-[p-(hydroxy)phenyl]glycyl- pantetheine (21b)}

The title compound was prepared and purified analogously to compound $21 \mathbf{a}$ by replacing 20a with 20b (146.9 mg, $0.18 \mathrm{mmol})$. The product was obtained as a white TFA salt (64.7 $\mathrm{mg}, 39 \%$ ). Isolation of $2 \mathrm{mg}$ of diasteromerically pure material was achieved using Analytical Method A. ${ }^{1} \mathrm{H}-\mathbf{N M R}\left(400 \mathrm{MHz} ; \mathrm{D}_{2} \mathrm{O}\right): \delta 7.28(\mathrm{~d}, J=8.7 \mathrm{~Hz}, 2 \mathrm{H}), 7.22(\mathrm{~d}, J=$ $8.7 \mathrm{~Hz}, 2 \mathrm{H}), 6.89(\mathrm{~d}, J=8.8 \mathrm{~Hz}, 2 \mathrm{H}), 6.84(\mathrm{~d}, J=8.8 \mathrm{~Hz}, 2 \mathrm{H}), 5.47(\mathrm{~s}, 1 \mathrm{H}), 5.06(\mathrm{~s}, 1 \mathrm{H})$, 4.75 (X of ABX, $J=6.4,4.8 \mathrm{~Hz}, 1 \mathrm{H}$ ), 4.14 (AB of ABX, $J=11.6,6.4,4.8 \mathrm{~Hz}, 2 \mathrm{H}), 3.87$ (s, $1 \mathrm{H}), 3.40(\mathrm{~d}, J=11.3 \mathrm{~Hz}, 1 \mathrm{H}), 3.31-3.26(\mathrm{~m}, 4 \mathrm{H}), 3.29(\mathrm{~d}, J=11.3 \mathrm{~Hz}, 1 \mathrm{H}), 3.08-2.97(\mathrm{~m}$, 2H), $2.20(\mathrm{td}, J=6.6,2.1 \mathrm{~Hz}, 2 \mathrm{H}), 1.69(\mathrm{~s}, 3 \mathrm{H}), 0.81(\mathrm{~s}, 3 \mathrm{H}), 0.77(\mathrm{~s}, 3 \mathrm{H}) .{ }^{13} \mathrm{C}-\mathrm{NMR}(101$ $\left.\mathrm{MHz}, \mathrm{D}_{2} \mathrm{O}\right): \delta 201.0,175.0,173.9,173.2,169.9,169.0,157.3,156.4,129.8,129.7,126.5$, 123.5, 116.3, 116.0, 75.7, 68.4, 63.6, 62.9, 56.0, 52.3, 38.6, 38.3, 35.3, 35.1, 20.4, 19.7, 19.1. HRMS (FAB) calculated for $\mathrm{C}_{32} \mathrm{H}_{43} \mathrm{~N}_{5} \mathrm{O}_{11} \mathrm{~S}$ 706.27580; Found $706.27532[\mathrm{M}+\mathrm{H}]^{+}$.

\section{L-[p-(Benzyloxy)phenyl]glycine tert-butyl ester Toluenesulfonate (22a)}

To a $500 \mathrm{~mL}$ pressure bottle equipped with a magnetic stir bar, $\mathrm{L}-[p$ (benzyloxy)phenyl]glycine ${ }^{14}(10.00 \mathrm{~g}, 49.4 \mathrm{mmol})$ was suspended in $100 \mathrm{~mL}$ of reagentgrade dioxane containing $10 \mathrm{~mL}$ of concentrated sulfuric acid and cooled to $0{ }^{\circ} \mathrm{C}$ in an icebath. In a separate $125 \mathrm{~mL}$ Erlenmeyer flask, isobutylene ( $100 \mathrm{~mL}$ of liquid) was condensed from gas at $-78{ }^{\circ} \mathrm{C}$, and the liquid was quickly added to the pressure bottle and sealed. The contents of the pressure bottle were stirred at room temperature for $12 \mathrm{~h}$. The solution was cooled to $0{ }^{\circ} \mathrm{C}$ with an ice-bath and the solution was quickly poured into an ice-cold mixture of $400 \mathrm{~mL}$ of $1.0 \mathrm{M} \mathrm{NaOH}$ and $500 \mathrm{~mL} \mathrm{Et}_{2} \mathrm{O}$. The mixture was transferred to a $1 \mathrm{~L}$ separatory flask, the organics were partitioned and set aside and the aqueous layer was washed with $\mathrm{Et}_{2} \mathrm{O}(2 \times 100 \mathrm{~mL})$. The organic fractions were combined, dried with brine $(2 \times$ $100 \mathrm{~mL}$ ) and concentrated in vacuo to approximately $150 \mathrm{~mL}$. This ethereal solution was added to a separate flask containing $p$-toluene sulfonic acid monohydrate $(9.40 \mathrm{~g}, 49.4$ 
$\mathrm{mmol}$ ) in $200 \mathrm{~mL} \mathrm{Et}_{2} \mathrm{O}$, which precipitated the product. The precipitate was filtered and dried under high vacuum to afford the product as a white salt $(15.35 \mathrm{~g}, 64 \%)$. $[\mathrm{a}]_{\mathrm{D}}{ }^{25}=44.4$ $(\mathrm{c}=1.0, \mathrm{MeOH}) ;{ }^{1} \mathbf{H}-\mathrm{NMR}(400 \mathrm{MHz}$; DMSO-d 6 $\delta 8.68(\mathrm{br} \mathrm{s}, 3 \mathrm{H}), 7.50(\mathrm{~d}, J=8.0 \mathrm{~Hz}$, $2 \mathrm{H}), 7.45-7.34(\mathrm{~m}, 7 \mathrm{H}), 7.13(\mathrm{~d}, J=7.0 \mathrm{~Hz}, 2 \mathrm{H}), 7.11(\mathrm{~d}, J=8.7 \mathrm{~Hz}, 2 \mathrm{H}), 5.15(\mathrm{~s}, 2 \mathrm{H}), 5.07$ (br q., $J=5.4 \mathrm{~Hz}, 1 \mathrm{H}), 2.30$ (s, 3H), 1.38 (s, 9H). ${ }^{\mathbf{1 3}} \mathbf{C}-\mathbf{N M R}(101 \mathrm{MHz}$, DMSO-d 6 ): $\delta$ 168.2, 159.5, 146.0, 138.2, 137.2, 130.0, 128.9, 128.6, 128.4, 128.2, 128.1, 126.0, 125.5, 115.7, 100.0, 83.6, 69.7, 55.8, 27.9, 21.3. HRMS (FAB) calculated for $\mathrm{C}_{19} \mathrm{H}_{24} \mathrm{NO}_{3}$ 314.17562; Found $314.17537[\mathrm{M}+\mathrm{H}]^{+}$.

\section{D-[p-(Benzyloxy)phenyl]glycine tert-butyl ester Toluenesulfonate (22b)}

The title compound was prepared and purified analogously to compound 22a by replacing L[p-(benzyloxy)phenyl]glycine with ${ }_{\mathrm{D}}-\left[p\right.$-(benzyloxy)phenyl]glycine ${ }^{14}(10.0 \mathrm{~g}, 49.4 \mathrm{mmol})$. The product was obtained as a white salt $(15.59 \mathrm{~g}, 65 \%)$. $[\mathrm{a}]_{\mathrm{D}}{ }^{25}=-45.7(\mathrm{c}=1.0$, MeOH); ${ }^{\mathbf{1}} \mathbf{H}-\mathrm{NMR}(400 \mathrm{MHz}$; DMSO-d 6 ): $\delta 8.68(\mathrm{br} \mathrm{s}, 3 \mathrm{H}), 7.50(\mathrm{~d}, J=8.0 \mathrm{~Hz}, 2 \mathrm{H})$, 7.45-7.34 (m, 7H), $7.13(\mathrm{~d}, J=7.0 \mathrm{~Hz}, 2 \mathrm{H}), 7.11(\mathrm{~d}, J=8.7 \mathrm{~Hz}, 2 \mathrm{H}), 5.15(\mathrm{~s}, 2 \mathrm{H}), 5.07$ (br q., $J=5.4 \mathrm{~Hz}, 1 \mathrm{H}), 2.30$ (s, 3H), 1.38 (s, 9H). ${ }^{13}$ C-NMR (101 MHz, DMSO-d 6 ): $\delta 168.2$, $159.5,146.0,138.2,137.2,130.0,128.9,128.6,128.4,128.2,128.1,126.0,125.5,115.7$, 100.0, 83.6, 69.7, 55.8, 27.9, 21.3. HRMS (FAB) calculated for $\mathrm{C}_{19} \mathrm{H}_{24} \mathrm{NO}_{3} 314.17562$; Found $314.17550[\mathrm{M}+\mathrm{H}]^{+}$.

\section{N-(4,6-Diphenyl-4-oxazolin-2-onyl)-_-seryl---[p- (benzyloxy)phenyl)glycine tert-butyl ester (23a)}

To a flame dried $250 \mathrm{~mL}$ round-bottomed flask equipped with a magnetic stir bar, L-Oxserine dicyclohexylammonium salt ${ }^{26}(7.50 \mathrm{~g}, 14.80 \mathrm{mmol})$ and DIEA $(2.57 \mathrm{~mL}, 14.80$ $\mathrm{mmol}$ ) were dissolved in $25 \mathrm{~mL}$ of reagent grade DMF and cooled to $0{ }^{\circ} \mathrm{C}$ in an ice bath. In a separate round-bottomed flask, 22a $(8.62 \mathrm{~g}, 17.76 \mathrm{mmol})$ was dissolved in $10 \mathrm{~mL}$ of reagent grade DMF and to it was added DIEA $(2.57 \mathrm{~mL}, 14.80 \mathrm{mmol})$ and cooled to $0{ }^{\circ} \mathrm{C}$. Once both solutions were sufficiently cooled, PyBOP $(9.24 \mathrm{~g}, 17.76 \mathrm{mmol})$ was added to the flask containing L-Ox-serine and after 1 min the flask containing 22a was transferred drop wise over $2 \mathrm{~min}$ to the activated acid. The reaction was stirred for $3 \mathrm{~h}$ from $0{ }^{\circ} \mathrm{C}$ to room temperature. The solution was diluted with $200 \mathrm{~mL}$ of EtOAc and washed with sat. aq. $\mathrm{NH}_{4} \mathrm{Cl}(2 \times 75 \mathrm{~mL})$, sat. aq. $\mathrm{NaHCO}_{3}(2 \times 75 \mathrm{~mL})$ and brine $(1 \times 75 \mathrm{~mL})$. The EtOAc was concentrated in vacuo to a viscous yellow oil and the product was purified as a white foam by silica gel chromatography with 60: $40 \mathrm{Hex}$ : EtOAc to afford the product as a white solid $(6.52 \mathrm{~g}, 71 \%) \cdot[\mathrm{a}]_{\mathrm{D}}{ }^{25}=39.8\left(\mathrm{c}=1.0\right.$, EtOAc); ${ }^{1} \mathbf{H}-\mathrm{NMR}(400 \mathrm{MHz} ;$ DMSO-d 6$): \delta 8.73(\mathrm{~d}, J$ $=6.8 \mathrm{~Hz}, 1 \mathrm{H}), 7.57-7.22(\mathrm{~m}, 16 \mathrm{H}), 7.12(\mathrm{~d}, J=7.0 \mathrm{~Hz}, 2 \mathrm{H}), 7.03(\mathrm{~d}, J=8.8 \mathrm{~Hz}, 2 \mathrm{H}), 5.28$ (br s, 1H), $5.20(\mathrm{~d}, J=6.8 \mathrm{~Hz}, 1 \mathrm{H}), 5.12(\mathrm{~s}, 2 \mathrm{H}), 4.21(\mathrm{dd}, J=9.0,5.8 \mathrm{~Hz}, 1 \mathrm{H}), 4.06-3.99$ $(\mathrm{m}, 1 \mathrm{H}), 3.91(\mathrm{dt}, J=11.2,5.7 \mathrm{~Hz}, 1 \mathrm{H}), 1.35(\mathrm{~s}, 9 \mathrm{H}) .{ }^{13} \mathbf{C}-\mathbf{N M R}(101 \mathrm{MHz}$, DMSO-d 6 ): $\delta$ 169.7, 166.7, 158.6, 153.8, 137.5, 133.5, 131.3, 130.8, 129.9, 129.4, 129.2, 128.9, 128.9, 128.3, 128.14, 128.08, 127.1, 125.2, 124.1, 115.3, 81.7, 69.7, 59.4, 58.5, 57.1, 28.0. HRMS (FAB) calculated for $\mathrm{C}_{37} \mathrm{H}_{36} \mathrm{~N}_{2} \mathrm{O}_{7} 620.25225$; Found $620.25150[\mathrm{M}+\mathrm{H}]^{+}$.

\section{$N$-(4,6-Diphenyl-4-oxazolin-2-onyl)---seryl-o-[p-(benzyloxy)phenyl)glycine tert-buty ester} (23b)

The title compound was prepared and purified analogously to compound 23a by replacing 22a with 22b $(8.62 \mathrm{~g}, 17.76 \mathrm{mmol})$. The product was obtained as a white foam $(6.34 \mathrm{~g}$, $69 \%) \cdot[\mathrm{a}]_{\mathrm{D}}^{23}=-50.5\left(\mathrm{c}=1.0\right.$, EtOAc). ${ }^{1} \mathbf{H}-\mathrm{NMR}(400 \mathrm{MHz}$; DMSO-d 6$): \delta 8.68(\mathrm{~d}, J=7.2$ $\mathrm{Hz}, 1 \mathrm{H}), 7.59-7.23(\mathrm{~m}, 15 \mathrm{H}), 7.15(\mathrm{~d}, J=7.0 \mathrm{~Hz}, 2 \mathrm{H}), 7.03(\mathrm{~d}, J=8.8 \mathrm{~Hz}, 2 \mathrm{H}), 5.43(\mathrm{t}, J=$ $5.6 \mathrm{~Hz}, 1 \mathrm{H}), 5.22(\mathrm{~d}, J=7.2 \mathrm{~Hz}, 1 \mathrm{H}), 5.12(\mathrm{~s}, 2 \mathrm{H}), 4.23(\mathrm{dd}, J=8.3,6.3 \mathrm{~Hz}, 1 \mathrm{H}), 4.05-3.99$ (m, 1H), 3.86 (dt, $J=11.3,5.8 \mathrm{~Hz}, 1 \mathrm{H}), 1.34$ (s, 9H). ${ }^{13} \mathbf{C}-\mathbf{N M R}(101 \mathrm{MHz}$, DMSO-d 6 ): $\delta$ $169.8,167.1,158.6,153.8,137.5,133.5,131.3,130.8,130.0,129.2,129.2,128.9,128.9$, 
128.3, 128.2, 128.1, 128.1, 127.0, 125.2, 124.2, 115.3, 81.7, 69.7, 59.3, 58.6, 57.1, 28.0.

HRMS (FAB) calculated for $\mathrm{C}_{37} \mathrm{H}_{36} \mathrm{~N}_{2} \mathrm{O}_{7} 620.25225$; Found $620.25214[\mathrm{M}+\mathrm{H}]^{+}$.

\section{3-N-(4,5-Diphenyl-4-oxazolin-2-onyl)epi-aminonocardicin tert-butyl ester (24a)}

To a flame dried $100 \mathrm{~mL}$ round-bottomed flask equipped with a magnetic stir bar, 23a (3.28 $\mathrm{g}, 5.28 \mathrm{mmol}$ ) was dissolved in $30 \mathrm{~mL}$ of freshly distilled THF and the flask was wrapped with aluminum foil to exclude light. To this solution was added $\mathrm{P}(\mathrm{OEt})_{3}(1.09 \mathrm{~mL}, 6.34$ $\mathrm{mmol})$ and DEAD ( $994 \mu \mathrm{L}, 6.34 \mathrm{mmol})$ and the reaction was stirred at room temperature for $12 \mathrm{~h}$. The THF was removed in vacuo and the residue was purified by flash chromatography with an isocratic mobile phase of 60: 40, EtOAc: Hex to afford the product as a white foam $(2.99 \mathrm{~g}, 94 \%) \cdot[\mathrm{a}]_{\mathrm{D}}{ }^{22}=-99.6\left(\mathrm{c}=1.0\right.$, EtOAc). ${ }^{1} \mathbf{H}-\mathbf{N M R}\left(400 \mathrm{MHz} ;\right.$ DMSO-d $\left.{ }_{6}\right): \delta$ 7.58-7.17 (m, 17H), $7.02(\mathrm{~d}, J=8.7 \mathrm{~Hz}, 2 \mathrm{H}), 5.27(\mathrm{~s}, 1 \mathrm{H}), 5.09(\mathrm{~s}, 2 \mathrm{H}), 4.82(\mathrm{dd}, J=5.5$, $2.7 \mathrm{~Hz}, 1 \mathrm{H}), 3.97(\mathrm{dd}, J=5.6,2.7 \mathrm{~Hz}, 1 \mathrm{H}), 3.50(\mathrm{t}, J=5.7 \mathrm{~Hz}, 1 \mathrm{H}), 1.45(\mathrm{~s}, 9 \mathrm{H}) .{ }^{13} \mathbf{C}-\mathbf{N M R}$ $(101 \mathrm{MHz}$, DMSO-d 6 ): $\delta 167.2,163.1,158.3,152.0,136.9,133.6,130.7,130.4,129.6$, $128.8,128.7,128.4,128.0,127.8,127.7,127.2,126.2,125.5,124.0,123.4,114.9,82.2$, 69.2, 57.7, 56.6, 45.1, 27.5. HRMS (FAB) calculated for $\mathrm{C}_{37} \mathrm{H}_{34} \mathrm{~N}_{2} \mathrm{O}_{6} 602.24169$; Found $602.24039[\mathrm{M}+\mathrm{H}]^{+}$.

\section{3-N-(4,5-Diphenyl-4-oxazolin onyl)aminonocardicin tert-butyl ester (24b)}

The title compound was prepared and purified analogously to compound $\mathbf{2 4 a}$ by replacing 23a with 23b (3.28 g, $5.28 \mathrm{mmol})$. The product was obtained as a white solid (3.05 g, 96\%). $[\mathrm{a}]_{\mathrm{D}}{ }^{23}=-116.3\left(\mathrm{c}=1.0\right.$, EtOAc). ${ }^{1} \mathrm{H}-\mathrm{NMR}(400 \mathrm{MHz}$; DMSO-d 6 ): $87.59-7.14(\mathrm{~m}, 17 \mathrm{H})$, $7.05(\mathrm{~d}, J=8.8 \mathrm{~Hz}, 2 \mathrm{H}), 5.26(\mathrm{~s}, 1 \mathrm{H}), 5.14(\mathrm{~s}, 2 \mathrm{H}), 4.84(\mathrm{dd}, J=5.7,2.8 \mathrm{~Hz}, 1 \mathrm{H}), 3.69(\mathrm{t}, J$ $=5.7 \mathrm{~Hz}, 1 \mathrm{H}), 3.40(\mathrm{dd}, J=5.7,2.8 \mathrm{~Hz}, 1 \mathrm{H}), 1.38(\mathrm{~s}, 9 \mathrm{H}) .{ }^{13} \mathrm{C}-\mathbf{N M R}(101 \mathrm{MHz}$, DMSO$\left.\mathrm{d}_{6}\right): \delta 167.9,163.3,158.4,152.1,136.9,133.7,130.7,130.6,129.5,129.3,128.7,128.4$, 128.0, 127.9, 127.8, 127.1, 125.4, 125.2, 124.0, 123.2, 115.0, 82.2, 69.3, 57.6, 56.1, 44.8, 27.5. HRMS (FAB) calculated for $\mathrm{C}_{37} \mathrm{H}_{34} \mathrm{~N}_{2} \mathrm{O}_{6} 602.24169$; Found $602.24038[\mathrm{M}+\mathrm{H}]^{+}$.

\section{epi-3-Aminonocardicin tert-butyl ester Hydrochloride (25a)}

To a $250 \mathrm{~mL}$ pressure bottle, 24a (3.00 g, $4.98 \mathrm{mmol}$ ) was dissolved in $15 \mathrm{~mL}$ of reagent grade THF and to this was added a catalytic amount of Pd-OH/C. Hydrogenolysis was carried out over $48 \mathrm{~h}$ under $50 \mathrm{psi}$ of $\mathrm{H}_{2}$ on a Parr apparatus with vigorous shaking. The mixture was filtered through Celite and the Pd-OH/C was washed with THF $(3 \times 50 \mathrm{~mL})$. The filtrate was concentrated in vacuo to a viscous oil, which was partitioned into $30 \mathrm{~mL}$ $\mathrm{Et}_{2} \mathrm{O}$, and $10 \mathrm{~mL}$ water containing conc. $\mathrm{HCl}(457 \mu \mathrm{L}, 5.48 \mathrm{mmol})$. The aqueous layer was washed with $\mathrm{Et}_{2} \mathrm{O}(2 \times 30 \mathrm{~mL})$, flash frozen and lyophilized to dryness to afford the product as the white $\mathrm{HCl}$ salt $(1.46 \mathrm{~g}, 89 \%)$. $[\mathrm{a}]_{\mathrm{D}}{ }^{24}=101.9(\mathrm{c}=1.0, \mathrm{MeOH}) .{ }^{\mathbf{1}} \mathbf{H}-\mathbf{N M R}(400 \mathrm{MHz}$; DMSO-d $\left._{6}\right): \delta 9.76(\mathrm{~s}, 1 \mathrm{H}), 9.04(\mathrm{~s}, 3 \mathrm{H}), 7.14(\mathrm{~d}, J=8.6 \mathrm{~Hz}, 2 \mathrm{H}), 6.81(\mathrm{~d}, J=8.6 \mathrm{~Hz}, 2 \mathrm{H})$, $5.30(\mathrm{~s}, 1 \mathrm{H}), 4.48(\mathrm{dd}, J=5.4,2.4 \mathrm{~Hz}, 1 \mathrm{H}), 3.58(\mathrm{dd}, J=6.3,2.4 \mathrm{~Hz}, 1 \mathrm{H}), 3.43(\mathrm{t}, J=6.2$ $\mathrm{Hz}, 1 \mathrm{H}), 1.42(\mathrm{~s}, 9 \mathrm{H}) .{ }^{13} \mathrm{C}-\mathrm{NMR}\left(101 \mathrm{MHz}, \mathrm{DMSO}_{\mathrm{d}}\right)$ : $\delta$ 167.7, 162.1, 157.8, 129.0, 123.8, 115.7, 82.4, 57.8, 53.3, 44.2, 27.6. HRMS (FAB) calculated for $\mathrm{C}_{15} \mathrm{H}_{21} \mathrm{ClN}_{2} \mathrm{O}_{4}$ 293.15013; Found 293.14937 [M+H] $]^{+}$.

\section{Aminonocardicin tert-butyl ester Hydrochloride (25b)}

The title compound was prepared and purified analogously to compound 25a by replacing 24a with $24 b$ ( $3.00 \mathrm{~g}, 4.98 \mathrm{mmol})$. The product was obtained as a white $\mathrm{HCl}$ salt ( $1.51 \mathrm{~g}$, 92\%). $[\mathrm{a}]_{\mathrm{D}}{ }^{25}=-146.2\left(\mathrm{c}=1.0, \mathrm{MeOH} .{ }^{\mathbf{1}} \mathbf{H}-\mathbf{N M R}(400 \mathrm{MHz}\right.$; DMSO-d 6$): \delta 9.76$ (br s, $\left.1 \mathrm{H}\right)$, $8.93(\mathrm{br} \mathrm{s}, 2 \mathrm{H}), 7.16(\mathrm{~d}, J=8.6 \mathrm{~Hz}, 2 \mathrm{H}), 6.82(\mathrm{~d}, J=8.6 \mathrm{~Hz}, 2 \mathrm{H}), 5.33(\mathrm{~s}, 1 \mathrm{H}), 4.56(\mathrm{~d}, J=$ $3.9 \mathrm{~Hz}, 1 \mathrm{H}), 3.70(\mathrm{t}, J=5.8 \mathrm{~Hz}, 1 \mathrm{H}), 3.06(\mathrm{dd}, J=6.1,2.1 \mathrm{~Hz}, 1 \mathrm{H}), 1.40(\mathrm{~s}, 9 \mathrm{H}) .{ }^{13} \mathbf{C}-\mathbf{N M R}$ (101 MHz, DMSO-d ${ }_{6}$ ): $\delta$ 168.1, 162.2, 157.9, 129.5, 123.0, 115.7, 82.3, 57.7, 53.0, 43.8, 27.5. HRMS (FAB) calculated for $\mathrm{C}_{15} \mathrm{H}_{21} \mathrm{ClN}_{2} \mathrm{O}_{4} 293.15013$ Found $293.14955[\mathrm{M}+\mathrm{H}]^{+}$. 


\section{N-tert-Butyloxycarbonyl-o-[p-(hydroxy)phenyl]glycine (26)}

To a $500 \mathrm{~mL}$ Erlenmeyer flask equipped with a magnetic stir bar, D- $[p-$ (hydroxy)phenyl]glycine (20.00 g, $119.57 \mathrm{mmol})$ was dissolved in $300 \mathrm{~mL}$ of $1.0 \mathrm{M} \mathrm{NaOH}$ and to this was added di-tert-butyl dicarbonate $(31.31 \mathrm{~g}, 143.48 \mathrm{mmol})$ in $500 \mathrm{~mL}$ of reagent grade THF. The reaction was stirred at room temperature for $12 \mathrm{~h}$. The THF was partitioned with $200 \mathrm{~mL} \mathrm{Et}_{2} \mathrm{O}$ and separated. The aqueous layer was cooled to $0{ }^{\circ} \mathrm{C}$ in an ice-bath and acidified to $\mathrm{pH} 2.0$ with conc. $\mathrm{HCl}$. The acidified aqueous mixture was extracted with EtOAc $(3 \times 100 \mathrm{~mL})$ and the organic extractions were pooled, washed with brine $(1 \times 75$ $\mathrm{mL}$ ) and concentrated in vacuo to a viscous oil. The product was crystallized from EtOAc/ Hex as a white solid $(29.46 \mathrm{~g}, 97 \%)$. $\mathrm{mp} 198{ }^{\circ} \mathrm{C} ;[\mathrm{a}]_{\mathrm{D}}{ }^{25}=-133.7(\mathrm{c}=1.0, \mathrm{MeOH}) .{ }^{1} \mathbf{H}$ NMR (400 MHz; DMSO-d 6 ): $\delta 7.37$ (d, $J=8.1 \mathrm{~Hz}, 1 \mathrm{H}), 7.19(\mathrm{~d}, J=8.6 \mathrm{~Hz}, 2 \mathrm{H}), 6.73$ (d, $J$ $=8.6 \mathrm{~Hz}, 2 \mathrm{H}), 4.98(\mathrm{~d}, J=8.1 \mathrm{~Hz}, 1 \mathrm{H}), 1.39(\mathrm{~s}, 9 \mathrm{H}) .{ }^{13} \mathbf{C}-\mathbf{N M R}(101 \mathrm{MHz}$, DMSO-d 6$): \delta$ 172.9, 157.2, 155.3, 129.1, 127.7, 115.2, 78.4, 57.2, 28.3. HRMS (FAB) calculated for $\mathrm{C}_{13} \mathrm{H}_{17} \mathrm{NO}_{5}$ 268.11850; Found $268.11831[\mathrm{M}+\mathrm{H}]^{+}$.

\section{Protected epi-Nocardicin G (27a)}

To a flame-dried $100 \mathrm{~mL}$ round-bottomed flask equipped with a magnetic stir bar and an argon inlet, compound $\mathbf{2 6}$ (963 mg, $3.60 \mathrm{mmol}$ ) was dissolved in $10 \mathrm{~mL}$ of freshly distilled acetone. To this solution was added 2,6-lutidine $(370 \mu \mathrm{L}, 3.26 \mathrm{mmol})$ and a catalytic amount of $N$-methylmorpholine $(79 \mu \mathrm{L}, 0.72 \mathrm{mmol})$. The solution was cooled to $-50{ }^{\circ} \mathrm{C}$ with the aide of a dry ice/acetone bath. Once the solution was sufficiently cold, isobutyl chloroformate ( $427 \mu \mathrm{L}, 3.26 \mathrm{mmol}$ ), dissolved in $2 \mathrm{~mL}$ of freshly distilled acetone, was added drop wise to the solution containing 26 over 2 min. The solution was stirred at -50 to $-30{ }^{\circ} \mathrm{C}$ for 30 min during which time a precipitate formed. The dry ice/acetone bath was removed and replaced with an ice-bath and the mixture was stirred at $0{ }^{\circ} \mathrm{C}$ for an additional $20 \mathrm{~min}$.

To a separate $50 \mathrm{~mL}$ pear-shaped flask, $25 \mathrm{a}(789 \mathrm{mg}, 2.40 \mathrm{mmol})$ was dissolved in $5 \mathrm{~mL}$ of reagent grade DMF along with 2,6-lutidene $(370 \mu \mathrm{L}, 3.26 \mathrm{mmol})$ and cooled to $0{ }^{\circ} \mathrm{C}$ in an ice-bath. The solution was added drop wise over 2 min to the mixture containing the mixed anhydride. The reaction mixture was stirred at $0{ }^{\circ} \mathrm{C}$ for 30 minutes, warmed to room temperature by removal of the ice-bath and stirred for an additional $3 \mathrm{~h}$. The solution was diluted with $150 \mathrm{~mL}$ of EtOAc and washed with sat. aq. $\mathrm{NH}_{4} \mathrm{Cl}(2 \times 40 \mathrm{~mL})$, sat. aq. $\mathrm{NaHCO}_{3}(1 \times 40 \mathrm{~mL})$ and brine $(1 \times 40 \mathrm{~mL})$. The dried EtOAc extract was concentrated in vacuo to a viscous yellow oil, which was purified by silica gel flash chromatography using an isocratic mobile phase 60: 40 EtOAc: Hex to afford the product as a white foam (832 mg, $64 \%) \cdot[\mathrm{a}]_{\mathrm{D}}{ }^{22}=0.80(\mathrm{c}=1.0, \mathrm{MeOH}) .{ }^{1} \mathbf{H}-\mathbf{N M R}(400 \mathrm{MHz}$; DMSO-d 6$): \delta 9.60(\mathrm{~s}, 1 \mathrm{H}), 9.39$ (s, $1 \mathrm{H}), 8.87(\mathrm{~d}, J=7.9 \mathrm{~Hz}, 1 \mathrm{H}), 7.17(\mathrm{~d}, J=8.6 \mathrm{~Hz}, 2 \mathrm{H}), 7.10(\mathrm{~d}, J=8.6 \mathrm{~Hz}, 2 \mathrm{H}), 6.76(\mathrm{~d}$, $J=8.6 \mathrm{~Hz}, 2 \mathrm{H}), 6.68(\mathrm{~d}, J=8.6 \mathrm{~Hz}, 2 \mathrm{H}), 5.25(\mathrm{~s}, 1 \mathrm{H}), 5.08(\mathrm{~d}, J=8.6 \mathrm{~Hz}, 1 \mathrm{H}), 4.81$ (ddd, $J$ $=7.8,5.2,2.7 \mathrm{~Hz}, 1 \mathrm{H}), 3.30(\mathrm{t}, J=5.3 \mathrm{~Hz}, 1 \mathrm{H}), 3.26(\mathrm{dd}, J=4.1,2.2), 1.39(\mathrm{~s}, 9 \mathrm{H}), 1.37(\mathrm{~s}$, 9H). ${ }^{13}$ C-NMR (101 MHz, DMSO-d 6 ): $\delta 171.3,168.6,166.3,157.9,157.3,155.3,129.5$, 129.1, 128.9, 124.6, 116.1, 115.4, 82.4, 78.8, 57.9, 55.4, 28.7, 28.0. HRMS (FAB) calculated for $\mathrm{C}_{28} \mathrm{H}_{35} \mathrm{~N}_{3} \mathrm{O}_{8} 542.25024$; Found $542.2496[\mathrm{M}+\mathrm{H}]^{+}$.

\section{Protected Nocardicin G (27b)}

The title compound was prepared and purified analogously to compound 27a by replacing 25a with $25 \mathbf{b}(789 \mathrm{mg}, 2.40 \mathrm{mmol})$. The product was obtained as a white foam $(871 \mathrm{mg}$, 67\%). $[\mathrm{a}]_{\mathrm{D}}{ }^{24}=-141.0(\mathrm{c}=1.0, \mathrm{MeOH}) .1 \mathrm{H}-\mathrm{NMR}(400 \mathrm{MHz}$; DMSO-d 6$): \delta 9.63(\mathrm{~s}, 1 \mathrm{H})$, $9.39(\mathrm{~s}, 1 \mathrm{H}), 8.77(\mathrm{~d}, J=8.1 \mathrm{~Hz}, 1 \mathrm{H}), 7.13(\mathrm{~d}, J=8.4 \mathrm{~Hz}, 4 \mathrm{H}), 6.78(\mathrm{~d}, J=8.6 \mathrm{~Hz}, 3 \mathrm{H})$, $6.67(\mathrm{~d}, J=8.6 \mathrm{~Hz}, 3 \mathrm{H}), 5.29(\mathrm{~s}, 1 \mathrm{H}), 5.00(\mathrm{~d}, J=8.4 \mathrm{~Hz}, 1 \mathrm{H}), 4.88-4.85(\mathrm{~m}, 1 \mathrm{H}), 3.67$ (t, $J$ $=5.3 \mathrm{~Hz}, 1 \mathrm{H}), 2.88-2.87(\mathrm{~m}, 1 \mathrm{H}), 1.40(\mathrm{~s}, 9 \mathrm{H}), 1.36(\mathrm{~s}, 9 \mathrm{H}) .{ }^{13} \mathbf{C}-\mathbf{N M R}(101 \mathrm{MHz}$, DMSO- 
$\left.\mathrm{d}_{6}\right): \delta 171.2,168.8,166.6,158.0,157.3,155.3,129.8,129.1,128.9,124.3,116.1,115.4$, 82.4, 78.8, 57.9, 55.1, 28.6, 28.0. HRMS (FAB) calculated for $\mathrm{C}_{28} \mathrm{H}_{35} \mathrm{~N}_{3} \mathrm{O}_{8} 542.25024$; Found $542.24950[\mathrm{M}+\mathrm{H}]^{+}$.

\section{N-tert-Butyloxycarbonyl-epi-Nocardicin G (28a)}

To a $100 \mathrm{~mL}$ round-bottomed flask, equipped with a magnetic stir bar, $\mathbf{2 7 a}(470 \mathrm{mg}, 0.88$ $\mathrm{mmol}$ ) was dissolved in $20 \mathrm{~mL}$ of reagent grade TFA and stirred at room temperature for 30 min. The TFA was evaporated under reduced pressure and residual TFA was removed by azeotropic distillation with toluene $(2 \times 50 \mathrm{~mL})$ to provide an orange oil. To this oil was added $10 \mathrm{~mL}$ of reagent grade THF, $2 \mathrm{~mL}$ of water and DIEA $(459 \mu \mathrm{L}, 2.63 \mathrm{mmol})$.

To a separate $50 \mathrm{~mL}$ round-bottomed flask, di-tert-butyl dicarbonate (227 mg, $1.4 \mathrm{mmol})$ was dissolved in $5 \mathrm{~mL}$ of THF and transferred drop wise over 2 min to the flask containing freshly deprotected 27a. The reaction was stirred at room temperature for $12 \mathrm{~h}$. The solution was diluted with $50 \mathrm{~mL}$ of EtOAc and washed with sat. aq. $\mathrm{NH}_{4} \mathrm{Cl}(2 \times 20 \mathrm{~mL})$. The EtOAc was concentrated in vacuo to yield a yellow foam. The yellow foam was purified by flash silica gel chromatography, eluting with an isocratic mobile phase 70: 30 EtOAc: Hex supplemented with $1 \%$ acetic acid. The product was obatained as a light yellow solid (421 $\mathrm{mg}, 73 \%) .[\mathrm{a}]_{\mathrm{D}}{ }^{22}=17.7(\mathrm{c}=1.0, \mathrm{MeOH}) .{ }^{1} \mathbf{H}-\mathbf{N M R}\left(400 \mathrm{MHz}\right.$; DMSO-d $\left.{ }^{6}\right): \delta 13.15(\mathrm{br} \mathrm{s}$, $1 \mathrm{H}), 9.58(\mathrm{~s}, 1 \mathrm{H}), 9.39(\mathrm{~s}, 1 \mathrm{H}), 8.90(\mathrm{~d}, J=7.5 \mathrm{~Hz}, 1 \mathrm{H}), 7.17(\mathrm{~d}, J=8.6 \mathrm{~Hz}, 2 \mathrm{H}), 7.13(\mathrm{~d}, J$ $=8.6 \mathrm{~Hz}, 2 \mathrm{H}), 6.68(\mathrm{~d}, J=8.6 \mathrm{~Hz}, 2 \mathrm{H}), 5.28(\mathrm{~s}, 1 \mathrm{H}), 5.08(\mathrm{~d}, J=8.5 \mathrm{~Hz}, 1 \mathrm{H}), 4.85(\mathrm{ddd}, J=$ 8.0, 5.3, $2.6 \mathrm{~Hz}, 1 \mathrm{H}), 3.34(\mathrm{t}, J=5.3 \mathrm{~Hz}, 1 \mathrm{H}), 3.30(\mathrm{dd}, J=4.8,2.4 \mathrm{~Hz}, 1 \mathrm{H}), 1.37(\mathrm{~s}$, 9H). ${ }^{13}$ C-NMR (101 MHz, DMSO-d 6 ): $\delta 171.2,171.0,166.4,161.8,157.9,157.3,129.6$, 129.2, 128.9, 124.9, 116.0, 115.4, 82.1, 78.8, 57.4, 55.3, 47.3, 28.7. HRMS (FAB) calculated for $\mathrm{C}_{24} \mathrm{H}_{27} \mathrm{~N}_{3} \mathrm{O}_{8} 486.18764$; Found $486.18742[\mathrm{M}+\mathrm{H}]^{+}$.

\section{N-tert-Butyloxycarbonyl-Nocardicin G (28b)}

The title compound was prepared and purified analogously to compound 28a by replacing 27a with $\mathbf{2 7} \mathbf{b}$ ( $470 \mathrm{mg}, 0.88 \mathrm{mmol})$. The product was obtained as a light yellow solid (415 $\mathrm{mg}, 72 \%) \cdot[\mathrm{a}]_{\mathrm{D}}{ }^{25}=-166.2(\mathrm{c}=1.0, \mathrm{MeOH}) .{ }^{1} \mathbf{H}-\mathbf{N M R}\left(400 \mathrm{MHz}\right.$; DMSO-d $\left.{ }^{6}\right): \delta 13.15(\mathrm{br}$ $\mathrm{s}, 1 \mathrm{H}), 9.60(\mathrm{~s}, 1 \mathrm{H}), 9.39(\mathrm{~s}, 1 \mathrm{H}), 8.77(\mathrm{~d}, J=8.2 \mathrm{~Hz}, 1 \mathrm{H}), 7.15(\mathrm{~d}, J=8.0 \mathrm{~Hz}, 2 \mathrm{H}), 7.14(\mathrm{~d}$, $J=8.2 \mathrm{~Hz}, 2 \mathrm{H}), 6.78(\mathrm{~d}, J=8.6 \mathrm{~Hz}, 2 \mathrm{H}), 6.67(\mathrm{~d}, J=8.6 \mathrm{~Hz}, 2 \mathrm{H}), 5.32(\mathrm{~s}, 1 \mathrm{H}), 5.00(\mathrm{~d}, J=$ $8.6 \mathrm{~Hz}, 1 \mathrm{H}), 4.85(\mathrm{ddd}, J=7.7,5.0,2.4 \mathrm{~Hz}, 1 \mathrm{H}), 3.69(\mathrm{t}, J=5.3 \mathrm{~Hz}, 1 \mathrm{H}), 2.89(\mathrm{t}, J=2.2 \mathrm{~Hz}$, 1H), 1.36 (s, 9H). ${ }^{13}$ C-NMR (101 MHz, DMSO-d 6 ): $\delta 170.8,170.7,166.1,157.5,156.9$, $154.8,129.5,128.6,128.4,124.1,115.5,115.0,78.3,64.9,56.9,54.6,46.4,28.2$. HRMS (FAB) calculated for $\mathrm{C}_{24} \mathrm{H}_{27} \mathrm{~N}_{3} \mathrm{O}_{8} 486.18764$; Found $486.18738[\mathrm{M}+\mathrm{H}]^{+}$.

\section{epi-Nocardicin G-pantetheine (29a)}

To a $10 \mathrm{~mL}$ round- bottomed flask equipped with a magnetic stir bar, $28 \mathbf{a}(49 \mathrm{mg}, 0.10$ mmol) was dissolved in $2 \mathrm{~mL}$ of reagent grade DMF and to this solution was added $\mathrm{K}_{2} \mathrm{CO}_{3}$ (42 mg, $0.30 \mathrm{mmol}$ ) and cooled to $0^{\circ} \mathrm{C}$ with an ice-bath. To this cooled solution was added PyBOP (63 mg, $0.12 \mathrm{mmol}$ ) followed by $11(39 \mathrm{mg}, 0.12 \mathrm{mmol})$ and the reaction mixture was stirred for $30 \mathrm{~min}$ at room temperature. The solution was diluted with $40 \mathrm{~mL}$ of EtOAc and washed with sat. aq. $\mathrm{NH}_{4} \mathrm{Cl}(2 \times 20 \mathrm{~mL})$, sat. aq. $\mathrm{NaHCO}_{3}(1 \times 20 \mathrm{~mL})$ and brine $(1 \times$ $20 \mathrm{~mL}$ ). The EtOAc was concentrated in vacuo to a viscous oil, which was re-dissolved in 2 mL 70: 30 ACN: $\mathrm{H}_{2} \mathrm{O}$. The product was purified by Prep Method B, collected, frozen on dry ice and lyophilized to dryness. The lyophilized powder was dissolved in $5 \mathrm{~mL}$ of reagent grade TFA and stirred at room temperature for $15 \mathrm{~min}$. The TFA was removed in vacuo and the residue was re-suspended in $2 \mathrm{~mL}$ of $70: 30 \mathrm{H}_{2} \mathrm{O}$ : ACN supplemented with $0.1 \%$ TFA. The freshly deprotected product was purified by Prep Method A, collected on dry ice and lyophilized to dryness to provide the product as a white TFA salt (32 mg, 41\%). Isolation of 
$2 \mathrm{mg}$ of diasteromerically pure material was achieved using Analytical Method B. ${ }^{1} \mathbf{H}-\mathbf{N M R}$ $\left(400 \mathrm{MHz} ; \mathrm{D}_{2} \mathrm{O}\right): \delta 7.26(\mathrm{~d}, J=8.7 \mathrm{~Hz}, 2 \mathrm{H}), 7.16(\mathrm{~d}, J=8.7 \mathrm{~Hz}, 2 \mathrm{H}), 6.88(\mathrm{~d}, J=8.6 \mathrm{~Hz}$, $2 \mathrm{H}), 6.84(\mathrm{~d}, J=8.5 \mathrm{~Hz}, 2 \mathrm{H}), 5.54(\mathrm{~s}, 1 \mathrm{H}), 5.02(\mathrm{~s}, 1 \mathrm{H}), 4.76(\mathrm{dd}, J=7.6,2.1 \mathrm{~Hz}, 1 \mathrm{H}), 3.86$ $(\mathrm{s}, 1 \mathrm{H}), 3.43(\mathrm{t}, J=5.4 \mathrm{~Hz}, 1 \mathrm{H}), 3.40-3.27(\mathrm{~m}, 5 \mathrm{H}), 3.39(\mathrm{~d}, J=11.2 \mathrm{~Hz}, 1 \mathrm{H}), 3.28(\mathrm{~d}, J=$ $11.2 \mathrm{~Hz}, 1 \mathrm{H}$ ), 3.02 (app td, $J=6.3,2.5 \mathrm{~Hz}, 2 \mathrm{H}), 2.28-2.24(\mathrm{~m}, 2 \mathrm{H}), 0.78(\mathrm{~s}, 3 \mathrm{H}), 0.74(\mathrm{~s}$, 3H). ${ }^{13}$ C-NMR (101 MHz, $\left.\mathrm{D}_{2} \mathrm{O}\right): \delta$ 199.3, 175.0, 173.9, 168.1, 162.8, 157.3, 156.6, 130.6, 130.6, 130.0, 123.9, 123.3, 116.4, 116.0, 75.7, 68.4, 64.9, 54.8, 47.5, 38.6, 38.3, 38.3, 35.3, 35.2, 28.5, 28.5, 20.5, 19.1. HRMS (FAB) calculated for $\mathrm{C}_{30} \mathrm{H}_{39} \mathrm{~N}_{5} \mathrm{O}_{9} \mathrm{~S} 646.25468$ Found $646.25354[\mathrm{M}+\mathrm{H}]^{+}$.

\section{Nocardicin G-pantetheine (29b)}

The title compound was prepared and purified analogously to compound 29a by replacing 28a with $\mathbf{2 8 b}$ (49 $\mathrm{mg}, 0.10 \mathrm{mmol}$ ). The product was obtained as a TFA salt (34 $\mathrm{mg}, 44 \%$ ). Isolation of $2 \mathrm{mg}$ of diasteromerically pure material was achieved using Analytical Method B. ${ }^{1} \mathbf{H}-N M R\left(400 \mathrm{MHz} ; \mathrm{D}_{2} \mathrm{O}\right): 87.21(\mathrm{~d}, J=8.5 \mathrm{~Hz}, 2 \mathrm{H}), 7.17(\mathrm{~d}, J=8.5 \mathrm{~Hz}, 2 \mathrm{H}), 6.84(2 \times$ d, $J=8.5 \mathrm{~Hz}, 4 \mathrm{H}), 5.56(\mathrm{~s}, 1 \mathrm{H}), 4.96(\mathrm{~s}, 1 \mathrm{H}), 4.80(\mathrm{dd}, J=4.4,1.3 \mathrm{~Hz}, 1 \mathrm{H}), 3.84(\mathrm{~s}, 1 \mathrm{H})$, $3.71(\mathrm{t}, J=5.6 \mathrm{~Hz}, 1 \mathrm{H}), 3.37(\mathrm{~d}, J=11.2 \mathrm{~Hz}, 1 \mathrm{H}), 3.33-3.24(\mathrm{~m}, 4 \mathrm{H}), 3.27(\mathrm{~d}, J=11.2 \mathrm{~Hz}$, $1 \mathrm{H}), 3.09$ (dd, $J=5.8,2.4 \mathrm{~Hz}, 1 \mathrm{H}), 3.02(\mathrm{t}, J=6.0 \mathrm{~Hz}, 3 \mathrm{H}), 2.26(\mathrm{td}, J=6.4,2.3 \mathrm{~Hz}, 2 \mathrm{H}$ ), $0.78(\mathrm{~s}, 3 \mathrm{H}), 0.73$ (s, 3H). ${ }^{13} \mathbf{C}-\mathbf{N M R}\left(101 \mathrm{MHz}, \mathrm{D}_{2} \mathrm{O}\right): \delta 199.8,175.0,174.0,169.1,168.8$, 157.3, 156.7, 130.8, 130.0, 123.8, 123.3, 116.4, 116.0, 75.7, 68.4, 65.0, 56.0, 54.6, 47.0, 38.6, 38.3, 35.4, 35.2, 28.5, 20.5, 19.1. HRMS (FAB) calculated for $\mathrm{C}_{30} \mathrm{H}_{39} \mathrm{~N}_{5} \mathrm{O}_{9} \mathrm{~S}$ 646.25468 Found $646.25398[\mathrm{M}+\mathrm{H}]^{+}$.

\section{epi-Nocardicin G-SNAC (30a)}

To a $10 \mathrm{~mL}$ round-bottomed flask equipped with a magnetic stir bar, 28a (276 mg, 0.57 $\mathrm{mmol}$ ) was dissolved in $2 \mathrm{~mL}$ of reagent grade DMF and to this solution was added DIEA $(297 \mu \mathrm{L}, 1.71 \mathrm{mmol})$ and cooled to $0{ }^{\circ} \mathrm{C}$ in an ice-bath. To this cooled solution was added PyBOP $(325 \mathrm{mg}, 0.63 \mathrm{mmol})$ followed by SNAC $(63 \mu \mathrm{L}, 0.63 \mathrm{mmol})$ and the reaction was stirred for $30 \mathrm{~min}$ at room temperature. The reaction mixture was diluted with $40 \mathrm{~mL}$ of EtOAc and washed with sat. aq. $\mathrm{NH}_{4} \mathrm{Cl}(2 \times 20 \mathrm{~mL})$, sat. aq. $\mathrm{NaHCO}_{3}(1 \times 20 \mathrm{~mL})$ and brine $(1 \times 20 \mathrm{~mL})$. The EtOAc was concentrated in vacuo to a viscous oil, which was redissolved in $2 \mathrm{~mL} 70: 30 \mathrm{ACN}: \mathrm{H}_{2} \mathrm{O}$. The reaction was purified by Prep Method A and the product was collected, frozen on dry ice and lyophilized to dryness. The lyophilized powder was dissolved in $5 \mathrm{~mL}$ of reagent grade TFA and stirred at room temperature for $15 \mathrm{~min}$. The TFA was removed in vacuo and the residue was re-suspended in $2 \mathrm{~mL}$ of $70: 30 \mathrm{H}_{2} \mathrm{O}$ : ACN supplemented with $0.1 \%$ TFA. The freshly deprotected product was purified by Prep Method A, collected, frozen on dry ice and lyophilized to dryness to provide the product as a white TFA salt (177 mg, 52\%). Isolation of $2 \mathrm{mg}$ of diasteromerically pure material was achieved using Analytical Method B. ${ }^{1} \mathbf{H}-\mathbf{N M R}\left(400 \mathrm{MHz} ; \mathrm{D}_{2} \mathrm{O}\right): \delta 7.27(\mathrm{~d}, J=8.7 \mathrm{~Hz}, 2 \mathrm{H})$, $7.15(\mathrm{~d}, J=8.7 \mathrm{~Hz}, 2 \mathrm{H}), 6.88(\mathrm{~d}, J=8.7 \mathrm{~Hz}, 2 \mathrm{H}), 6.84(\mathrm{~d}, J=8.6 \mathrm{~Hz}, 2 \mathrm{H}), 5.54(\mathrm{~s}, 1 \mathrm{H})$, $5.03(\mathrm{~s}, 1 \mathrm{H}), 4.77(\mathrm{dd}, J=5.2,2.6 \mathrm{~Hz}, 1 \mathrm{H}), 3.42(\mathrm{t}, J=5.6 \mathrm{~Hz}, 1 \mathrm{H}), 3.36(\mathrm{dd}, J=6.0,2.4$ $\mathrm{Hz}, 1 \mathrm{H}), 3.26(\mathrm{td}, J=6.2,1.7 \mathrm{~Hz}, 2 \mathrm{H}), 3.01(\mathrm{td}, J=6.2,1.8 \mathrm{~Hz}, 2 \mathrm{H}), 1.76(\mathrm{~s}, 3 \mathrm{H}) .{ }^{13} \mathrm{C}-$ NMR $\left(101 \mathrm{MHz}, \mathrm{D}_{2} \mathrm{O}\right): \delta 199.4,174.2,169.1,168.1,157.3,156.6,130.5,130.0,123.9$, 123.4, 116.4, 116.0, 64.9, 56.0, 54.8, 47.5, 38.3, 28.4, 21.8. HRMS (ESI) calculated for $\mathrm{C}_{23} \mathrm{H}_{26} \mathrm{~N}_{4} \mathrm{O}_{6} \mathrm{~S} 487.16458$ Found $487.1641[\mathrm{M}+\mathrm{H}]^{+}$.

\section{Nocardicin G-SNAC (30b)}

The title compound was prepared and purified analogously to compound $\mathbf{3 0 a}$ by replacing 28a with 28b (276 mg, $0.57 \mathrm{mmol}$ ). The product was obtained as a white TFA salt (187 $\mathrm{mg}$, $55 \%$ ). Isolation of $2 \mathrm{mg}$ of diasteromerically pure material was achieved using Analytical Method B. ${ }^{1} \mathbf{H}-\mathbf{N M R}\left(400 \mathrm{MHz} ; \mathrm{D}_{2} \mathrm{O}\right): \delta 7.21(\mathrm{~d}, J=8.7 \mathrm{~Hz}, 2 \mathrm{H}), 7.16(\mathrm{~d}, J=8.7 \mathrm{~Hz}, 2 \mathrm{H})$, 
$6.84(\mathrm{~d}, J=8.7 \mathrm{~Hz}, 2 \mathrm{H}), 6.84(\mathrm{~d}, J=8.7 \mathrm{~Hz}, 2 \mathrm{H}), 5.55(\mathrm{~s}, 1 \mathrm{H}), 4.96(\mathrm{~s}, 1 \mathrm{H}), 4.80(\mathrm{dd}, J=$ $5.3,2.6 \mathrm{~Hz}, 1 \mathrm{H}), 3.70(\mathrm{t}, J=5.6 \mathrm{~Hz}, 1 \mathrm{H}), 3.27(\mathrm{td}, J=6.1,3.4 \mathrm{~Hz}, 2 \mathrm{H}), 3.08(\mathrm{dd}, J=5.9$, $2.6 \mathrm{~Hz}, 1 \mathrm{H}), 3.02(\mathrm{t}, J=6.0 \mathrm{~Hz}, 2 \mathrm{H}), 1.77(\mathrm{~s}, 3 \mathrm{H}) .{ }^{13} \mathbf{C}-\mathbf{N M R}\left(101 \mathrm{MHz}, \mathrm{D}_{2} \mathrm{O}\right): \delta 199.8$, 174.2, 169.1, 168.8, 157.3, 156.6, 130.7, 130.0, 123.8, 123.2, 116.3, 116.0, 64.9, 56.0, 54.5, 47.0, 38.3, 28.4, 21.7. HRMS (ESI) calculated for $\mathrm{C}_{23} \mathrm{H}_{26} \mathrm{~N}_{4} \mathrm{O}_{6} \mathrm{~S} 487.16458$ Found $487.1641[\mathrm{M}+\mathrm{H}]^{+}$.

\section{L-[p-(hydroxy)phenyl]glycine---arginine-epi-nocardicin G-SNAC (31 a)}

To a $100 \mathrm{~mL}$ round-bottomed flask equipped with a magnetic stir bar, compound $\mathbf{1 5}$ (281 $\mathrm{mg}, 0.37 \mathrm{mmol}$ ) was dissolved in $10 \mathrm{~mL}$ of reagent grade THF. To this solution was added a catalytic amount of $\mathrm{Pd}-\mathrm{OH} / \mathrm{C}$ and the dipeptide was hydrogenated under 1 atm. of $\mathrm{H}_{2}$ at room temperature for $12 \mathrm{~h}$. The mixture was filtered through Celite, washed with THF $(3 \times$ $50 \mathrm{~mL}$ ) and the filtrate was concentrated in vacuo and used without further purification.

In a separate $10 \mathrm{~mL}$ round-bottomed flask equipped with a magnetic stir bar, a mixture of 30a and 30b (200 mg, $0.33 \mathrm{mmol}$ ) was dissolved in $5 \mathrm{~mL}$ of reagent grade DMF containing $\mathrm{K}_{2} \mathrm{CO}_{3}(92 \mathrm{mg}, 0.67 \mathrm{mmol})$ and cooled to $0{ }^{\circ} \mathrm{C}$ in an ice bath. To a separate $10 \mathrm{~mL}$ roundbottomed flask, freshly deprotected 15 was dissolved in $2 \mathrm{~mL}$ of reagent grade $\mathrm{DMF}$ and to this was added $\mathrm{K}_{2} \mathrm{CO}_{3}$ (46 mg, $0.33 \mathrm{mmol}$ ) and cooled to $0{ }^{\circ} \mathrm{C}$ with an ice bath. Once both solutions were sufficiently cooled, PyBOP $(160 \mathrm{mg}, 0.37 \mathrm{mmol})$ was added to the flask containing the carboxylic acid and after 1 min, the solution containing $25 \mathbf{a}$ and $25 \mathbf{b}$ was transferred drop-wise over $2 \mathrm{~min}$ to the activated acid. The reaction mixture was stirred at 0 ${ }^{\circ} \mathrm{C}$ for $30 \mathrm{~min}$ then at room temperature for $2 \mathrm{~h}$. The solution was diluted with $40 \mathrm{~mL}$ of EtOAc and washed with sat. aq. $\mathrm{NH}_{4} \mathrm{Cl}(2 \times 20 \mathrm{~mL}), \mathrm{NaHCO}_{3}(1 \times 20 \mathrm{~mL})$ and brine $(1 \times$ $20 \mathrm{~mL}$ ). The EtOAc was concentrated in vacuo to a viscous oil which was re-dissolved in 2 $\mathrm{mL}$ 70: 30 ACN: $\mathrm{H}_{2} \mathrm{O}$. The reaction mixture was purified by Prep Method B and the product was collected, frozen on dry ice and lyophilized to dryness. The lyophilized product was dissolved in $5 \mathrm{~mL}$ of reagent grade TFA and stirred at room temperature for $15 \mathrm{~min}$. The TFA was removed in vacuo and the residue was re-suspended in $2 \mathrm{~mL}$ of 70: $30 \mathrm{H}_{2} \mathrm{O}$ : ACN supplemented with $0.1 \%$ TFA. The freshly deprotected product was purified by Prep Method A to provide the product as a white TFA salt $(2 \mathrm{mg}, 7 \%)$. Isolation of $1 \mathrm{mg}$ of diasteromerically pure material was achieved using Analytical Method A. ${ }^{1} \mathbf{H}-\mathbf{N M R}$ (601 $\left.\mathrm{MHz} ; \mathrm{D}_{2} \mathrm{O}\right): \delta 7.19(\mathrm{~d}, J=8.6 \mathrm{~Hz}, 2 \mathrm{H}), 7.18(\mathrm{~d}, J=8.6 \mathrm{~Hz}, 2 \mathrm{H}), 7.10(\mathrm{~d}, J=8.6 \mathrm{~Hz}, 2 \mathrm{H})$, $6.86(\mathrm{~d}, J=8.6 \mathrm{~Hz}, 2 \mathrm{H}), 6.83(\mathrm{~d}, J=8.6 \mathrm{~Hz}, 2 \mathrm{H}), 6.75(\mathrm{~d}, J=8.6 \mathrm{~Hz}, 2 \mathrm{H}), 5.55(\mathrm{~s}, 1 \mathrm{H})$, $5.23(\mathrm{~s}, 1 \mathrm{H}), 5.00(\mathrm{~s}, 1 \mathrm{H}), 4.28(\mathrm{t}, J=7.3 \mathrm{~Hz}, 1 \mathrm{H}), 3.46-3.44(\mathrm{~m}, 1 \mathrm{H}) 3.45,3.42-3.40(\mathrm{~m}$, $1 \mathrm{H}), 3.29-3.26(\mathrm{~m}, 2 \mathrm{H}), 3.05-3.01(\mathrm{~m}, 4 \mathrm{H}), 1.76(\mathrm{~s}, 3 \mathrm{H}), 1.69-1.67(\mathrm{~m}, 2 \mathrm{H}), 1.51-1.42(\mathrm{~m}$, $1 \mathrm{H}), 1.41-1.35(\mathrm{~m}, 1 \mathrm{H})$. HRMS (FAB) calculated for $\mathrm{C}_{37} \mathrm{H}_{45} \mathrm{~N}_{9} \mathrm{O}_{9} \mathrm{~S} 792.31392$ Found $792.31368[\mathrm{M}+\mathrm{H}]^{+}$.

\section{L-[p-(hydroxy)phenyl]glycine---arginine-nocardicin G-SNAC (31b)}

The title compound was prepared and purified analogously to compound 31a. The product was obtained as a white TFA salt (3 mg, 10\%). Isolation of $1 \mathrm{mg}$ of diasteromerically pure material was achieved using Analytical Method B. ${ }^{1} \mathbf{H}-\mathbf{N M R}\left(601 \mathrm{MHz} ; \mathrm{D}_{2} \mathrm{O}\right): \delta 7.18(\mathrm{~d}, J$ $=8.3 \mathrm{~Hz}, 2 \mathrm{H}), 7.11(\mathrm{~d}, J=8.1 \mathrm{~Hz}, 2 \mathrm{H}), 7.05(\mathrm{~d}, J=8.4 \mathrm{~Hz}, 2 \mathrm{H}), 6.84(\mathrm{~d}, J=8.6 \mathrm{~Hz}, 2 \mathrm{H})$, $6.81(\mathrm{~d}, J=8.6 \mathrm{~Hz}, 2 \mathrm{H}), 6.67(\mathrm{~d}, J=8.6 \mathrm{~Hz}, 2 \mathrm{H}), 5.58(\mathrm{~s}, 1 \mathrm{H}), 5.14(\mathrm{~s}, 1 \mathrm{H}), 4.97(\mathrm{~s}, 1 \mathrm{H})$, $4.23(\mathrm{t}, J=7.4 \mathrm{~Hz}, 1 \mathrm{H}), 3.74(\mathrm{t}, J=5.4 \mathrm{~Hz}, 1 \mathrm{H}), 3.33-3.27(\mathrm{~m}, 2 \mathrm{H}), 3.15(\mathrm{dd}, J=5.1,2.0$ $\mathrm{Hz}, 1 \mathrm{H}), 3.07-3.02(\mathrm{~m}, 2 \mathrm{H}), 2.99$ (app td, $J=7.0,3.0 \mathrm{~Hz}, 2 \mathrm{H}), 1.80$ (s, 3H), 1.65-1.60 (m, $2 \mathrm{H}), 1.45-1.39(\mathrm{~m}, 1 \mathrm{H}), 1.36-1.31(\mathrm{~m}, 1 \mathrm{H})$. HRMS (FAB) calculated for $\mathrm{C}_{37} \mathrm{H}_{45} \mathrm{~N}_{9} \mathrm{O}_{9} \mathrm{~S}$ 792.31392 Found $792.31423[\mathrm{M}+\mathrm{H}]^{+}$. 


\section{Chemical EquNibrium Noc G-SNAC to epi-'-Noc G-SNAC Experiment}

To determine the rate of spontaneous chemical racemization of Noc G-SNAC 30b to epiNoc G-SNAC 30a at a biologically relevant $\mathrm{pH}, 500 \mu \mathrm{L}$ of $1.0 \mathrm{mM}$ Noc G-SNAC in $50 \mathrm{mM}$ $\mathrm{K}_{\mathrm{i}} \mathrm{PO}_{4}$, pH 7.5 were prepared. $25 \mu \mathrm{L}$ of the reaction solution was aliquoted into $15 \mu \mathrm{L}$ of a $0.2 \%$ TFA aqueous solution on ice at $\mathrm{t}=1,2,5,10,15,20,30,45,65,80,120$ and 180 min. Reactions were repeated in triplicate. Quenched reactions were analyzed via HPLC using analytical method B, monitoring absorption at $272 \mathrm{~nm}$. The rate of chemical equilibrium $\left(\mathrm{k}_{1}+\mathrm{k}_{2}\right)$ was calculated by fitting the data to a non-linear one-phase decay curve.

\section{Supplementary Material}

Refer to Web version on PubMed Central for supplementary material.

\section{Acknowledgments}

We warmly thank Dr. K. A. Moshos for chemical advice, helpful discussion and encouragement and Dr. I. P. Mortimer and Dr. K. Belecki for all HRMS data reported. We are deeply grateful to Dr. A. Majumdar and Dr. C. Moore for their NMR expertise, guidance and conduct of $400 \mathrm{MHz}$ and $600 \mathrm{MHz}$ cryoprobe experiments.

\section{References}

1. Hamed RB, Gomez-Castellanos JR, Henry L, Ducho C, McDonough MA, Schofield CJ. Nat. Prod. Rep. 2013; 30:21. [PubMed: 23135477]

2. Gunsior M, Breazeale SD, Lind AJ, Ravel J, Janc JW, Townsend CA. Chem. Biol. 2004; 11:927. [PubMed: 15271351]

3. Davidsen JM, Townsend CA. Chem. Biol. 2012; 19:297. [PubMed: 22365611]

4. Salituro GM, Townsend CA. J. Am. Chem. Soc. 1990; 112:760.

5. Townsend CA, Reeve AM, Salituro GM. J. Chem. Soc., Chem. Commun. 1988:1579.

6. Koglin A, Walsh CT. Nat. Prod. Rep. 2009; 26:987. [PubMed: 19636447]

7. Sieber SA, Marahiel MA. Chem. Rev. 2005; 105:715. [PubMed: 15700962]

8. Lambalot RH, Gehring AM, Flugel RS, Zuber P, LaCelle M, Marahiel MA, Reid R, Khosla C, Walsh CT. Chem. Biol. 1996; 3:923. [PubMed: 8939709]

9. Trauger JW, Kohli RM, Mootz HD, Marahiel MA, Walsh CT. Nature. 2000; 407:215. [PubMed: 11001063]

10. Ehmann DE, Trauger JW, Stachelhaus T, Walsh CT. Chem. Biol. 2000; 7:765. [PubMed: 11033080]

11. Walsh CT, Chen H, Keating TA, Hubbard BK, Losey HC, Luo L, Marshall CG, Miller DA, Patel HM. Curr. Opin. Struct. Biol. 2001; 5:525.

12. Davidsen JM, Bartley DM, Townsend CA. J. Am. Chem. Soc. 2013; 135:1749. [PubMed: 23330869]

13. Evans DA, Wood MR, Trotter BW, Richardson TI, Barrow JC, Katz JL. Angew. Chem. Int. Ed. 1998; 37:2700.

14. Kamiya T, Hashimoto M, Nakaguchi O, Oku T. Tetrahedron. 1979; 35:323.

15. ChemAxon. https://http://www.chemaxon.com/marvin/sketch/index.jsp

16. Freeman MF, Moshos KA, Bodner MJ, Li R, Townsend CA. Proc. Natl. Acad. Sci. USA. 2008; 105:11128. [PubMed: 18678912]

17. Townsend CA, Nguyen LT. J. Am. Chem. Soc. 1981; 103:4582.

18. Townsend CA, Brown AM. J. Am. Chem. Soc. 1982; 104:1748.

19. Townsend CA, Brown AM. J. Am. Chem. Soc. 1983; 105:913.

20. Townsend CA, Nguyen LT. Tetrahedron Lett. 1982; 23:4859.

21. McBride LJ, Caruthers MH. Tetrahedron Lett. 1983; 24:245. 
22. Berner S, Mühlegger K, Seliger H. Nucleic Acids Res. 1989; 17:853. [PubMed: 2922273]

23. Roach PL, Clifton IJ, Hensgens CM, Shibata N, Schofield CJ, Hajdu J, Baldwin JE. Nature. 1997; 387:827. [PubMed: 9194566]

24. Roach PL, Clifton IJ, Fülöp V, Harlos K, Barton GJ, Hajdu J, Andersson I, Schofield CJ, Baldwin JE. Nature. 1995; 375:700. [PubMed: 7791906]

25. Sheehan JC, Guziec FS Jr. J. Am. Chem. Soc. 1972; 94:6561.

26. Sheehan JC, Guziec FS Jr. J. Org. Chem. 1973; 38:3034. [PubMed: 4741306]

27. Townsend CA, Brown AM, Nguyen LT. J. Am. Chem. Soc. 1983; 105:919.

28. Hughes DL, Reamer RA, Bergan JJ, Grabowski E. J. Am. Chem. Soc. 2001; 110:6487.

29. Vaughan JR. J. Am. Chem. Soc. 1951:3547.

30. Coste J, Le-Nguyen D, Castro B. Tetrahedron Lett. 1990; 31:205.

31. El-Faham A, Funosas RS, Prohens R, Albericio F. Chem. Eur. J. 2009; 15:9404. [PubMed: 19621394]

32. Valeur E, Bradley M. Chem. Soc. Rev. 2009; 38:606. [PubMed: 19169468]

33. Long AAW, Nayler JHC, Smith H, Taylor T, Ward NJ. J. Chem. Soc. 1971:1920. 


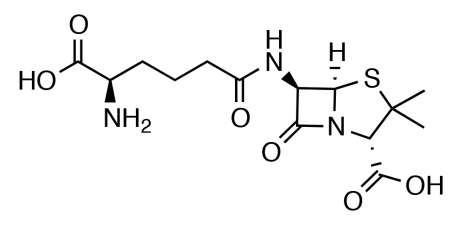

Pencillin N

1

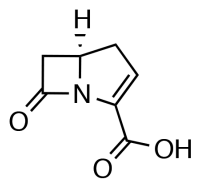

Carbapenem-

3-carboxylic acid

3<smiles>O=C(O)/C=C1/O[C@@H]2CC(=O)N2C1CO</smiles>

Clavulanic Acid

2<smiles>NC(CCOc1ccc(/C(=N/O)C(=O)N[C@H]2CN(C(C(=O)O)c3ccc(O)cc3)C2=O)cc1)C(=O)O</smiles>

Nocardicin A

4

Figure 1.

Representative structures of the four classes of naturally occurring $\beta$-lactam antibiotics. 

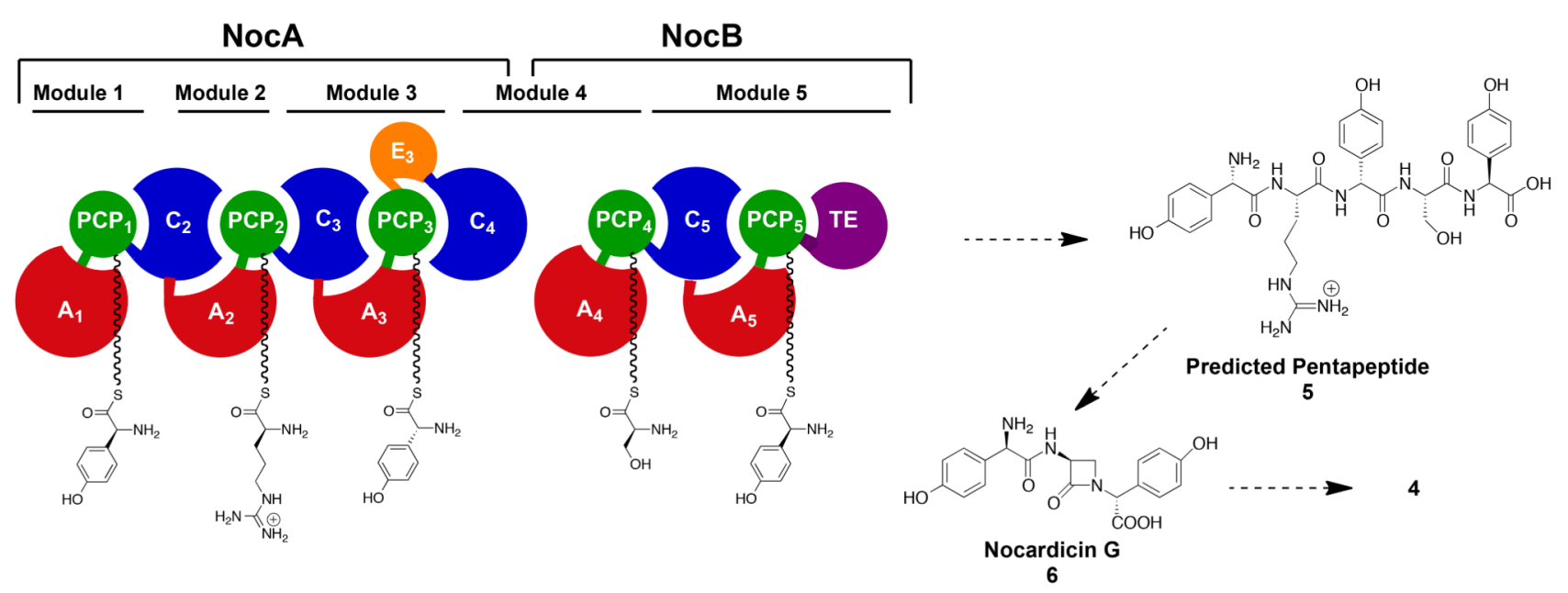

Figure 2. Hypothetical Biosynthesis of Nocardicin A.

NocA and NocB together contain five modules which are predicted to produce the pentapeptide L-pHPG-L-Arg-D-pHPG-L-Ser-L-pHPG (5) which then may go on to form the first $\beta$-lactam containing intermediate nocardicin $G(6)$ and ultimately nocardicin A (4). 
a.
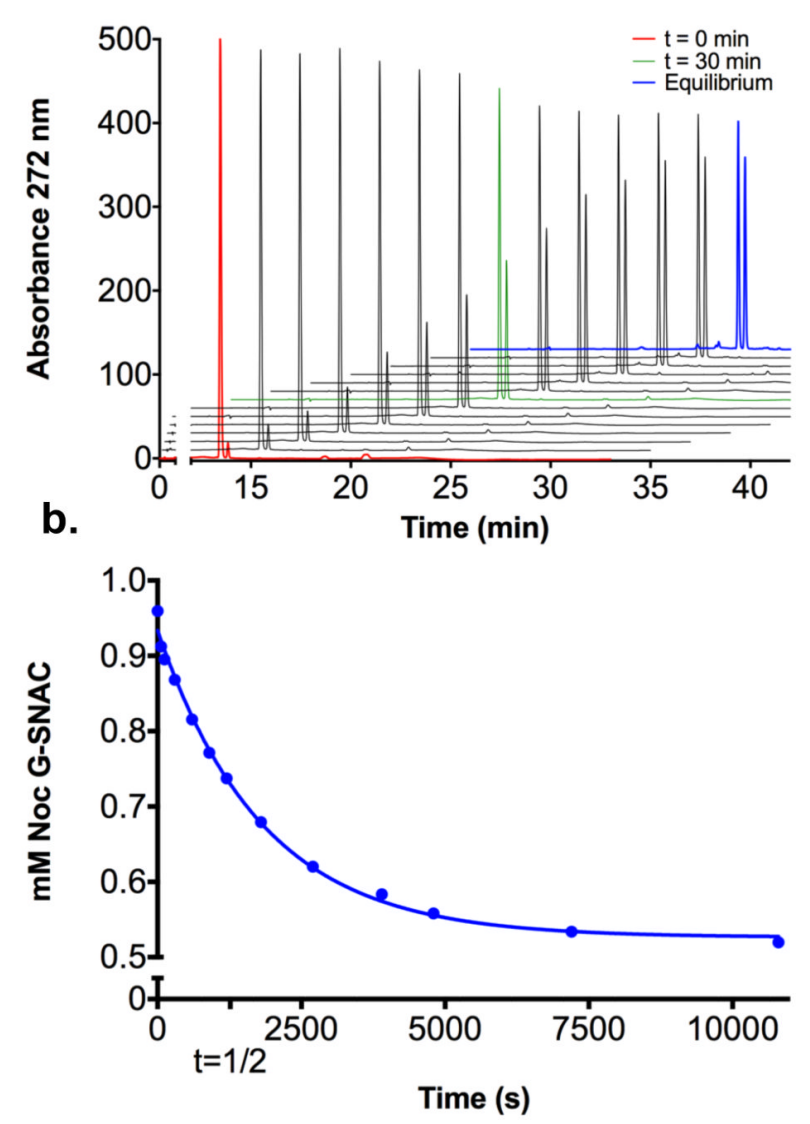

Figure 3. Chemical Equilibrium of Spontaneous Racemization of Nocardicin GSNAC to epiNocardicin G-SNAC.

a) HPLC analysis of chemical racemization of the a-hydrogen of the $C$-terminal pHPG in nocardicin G-SNAC in $50 \mathrm{mM} \mathrm{K}_{\mathrm{i}} \mathrm{PO}_{4}$ buffer at $\mathrm{pH} 7.5$ as a function of time. b) Extent of chemical epimerization was quantified and plotted as a one-phase exponential decay. The rate of chemical epimerization was measured to be $5.5(2) \times 10^{-4} \mathrm{sec}^{-1}\left(\mathrm{k}_{1}+\mathrm{k}_{2}\right)$. 


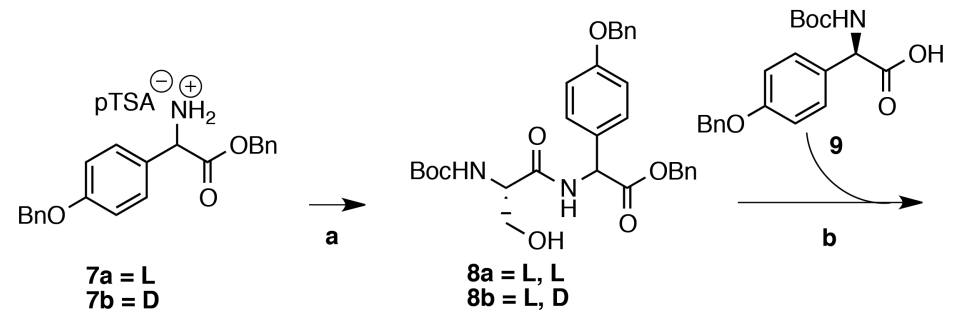

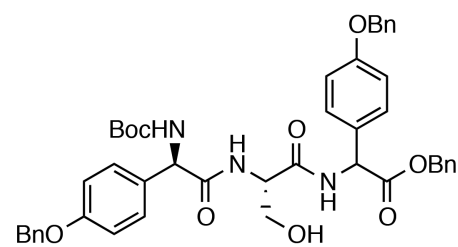

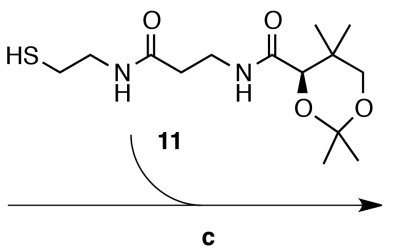

$10 \mathrm{a}=\mathrm{D}, \mathrm{L}, \mathrm{L}$
$10 \mathrm{~b}=\mathrm{D}, \mathrm{L}, \mathrm{D}$

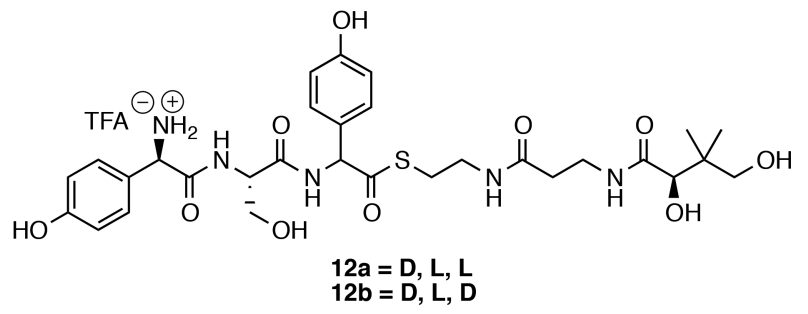

Reaction Conditions: a) Boc-L-Ser, PyBOP, DIEA, DMF, $76 \%$ b) 1. TFA 2. 9, PyBOP, DIEA, DMF, $72 \%$ c) 1. Pd$\mathrm{OH} / \mathrm{C}, \mathrm{H}_{2}$ (g) 50psi, THF 2. 11, PyBOP, $\mathrm{K}_{2} \mathrm{CO}_{3}$, DMF 3. TFA, $39 \%$ over 3 steps.

Scheme 1.

Synthesis of Linear Tripeptide Thioesters 

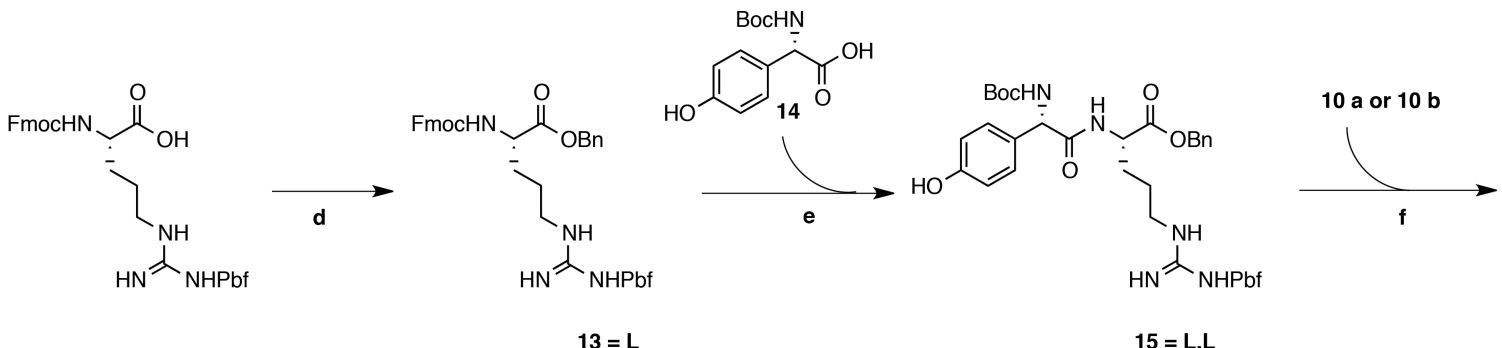

$13=L$

$$
15=\mathrm{L}, \mathrm{L}
$$

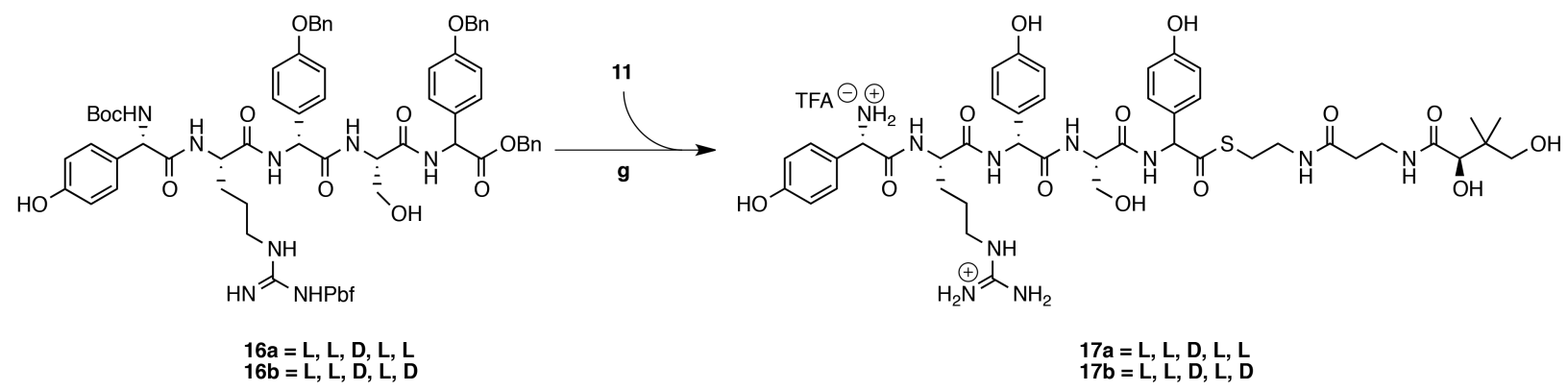

Reaction Conditions: d) Bn-Br, THF, DIPEA $40 \%$ e) $1.20 \%$ piperidine/THF 2. 13, PyBOP, DIPEA, DCM $43 \%$ over 2 steps f) 1 . Pd-OH/C, $\mathrm{H}_{2}$ (g) $50 \mathrm{psi}$, THF 2. TFA, 10 a or $10 \mathrm{~b} 3$. PyBOP, DIPEA, DCM $42 \%$ over 3 steps g) 1. Pd-OH/C $\mathrm{H}_{2}(\mathrm{~g}) 50 \mathrm{psi}$, THF 2. 11, PyBOP, $\mathrm{K}_{2} \mathrm{CO}_{3} 3$. TFA $35 \%$ over 3 steps.

Scheme 2.

Synthesis of Pentapeptide Thioesters 


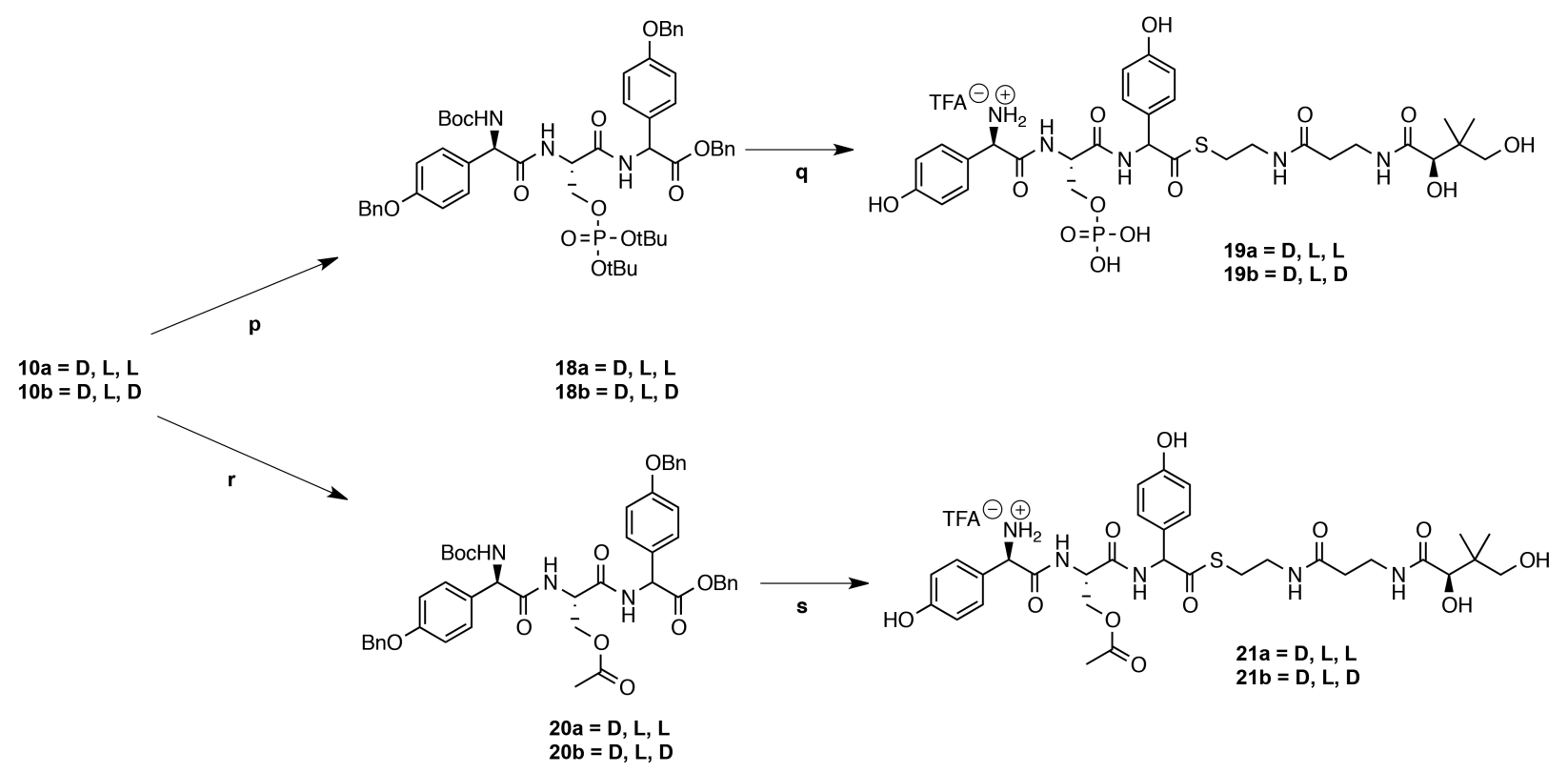

Reaction Conditions: p) 1. di-tert-butyl N,N-diisopropylphosphoramidite, tetrazole, THF 2. tert-butyl hydroperoxide, $64 \%$ over two steps q) 1 . Pd-OH/C, $\mathrm{H}_{2}(\mathrm{~g})$ 50psi, THF 2. 11, PyBOP, $\mathrm{K}_{2} \mathrm{CO}_{3}$, DMF 3 . TFA, $25 \%$ over three steps $r$ ) acetic anhydride, pyridine $99 \%$ s) $1.11, \mathrm{PyBOP}, \mathrm{K}_{2} \mathrm{CO}_{3}, \mathrm{DMF} 2$. TFA, $39 \%$ over two steps.

Scheme 3.

Synthesis of Activated Tripeptide Thioesters 

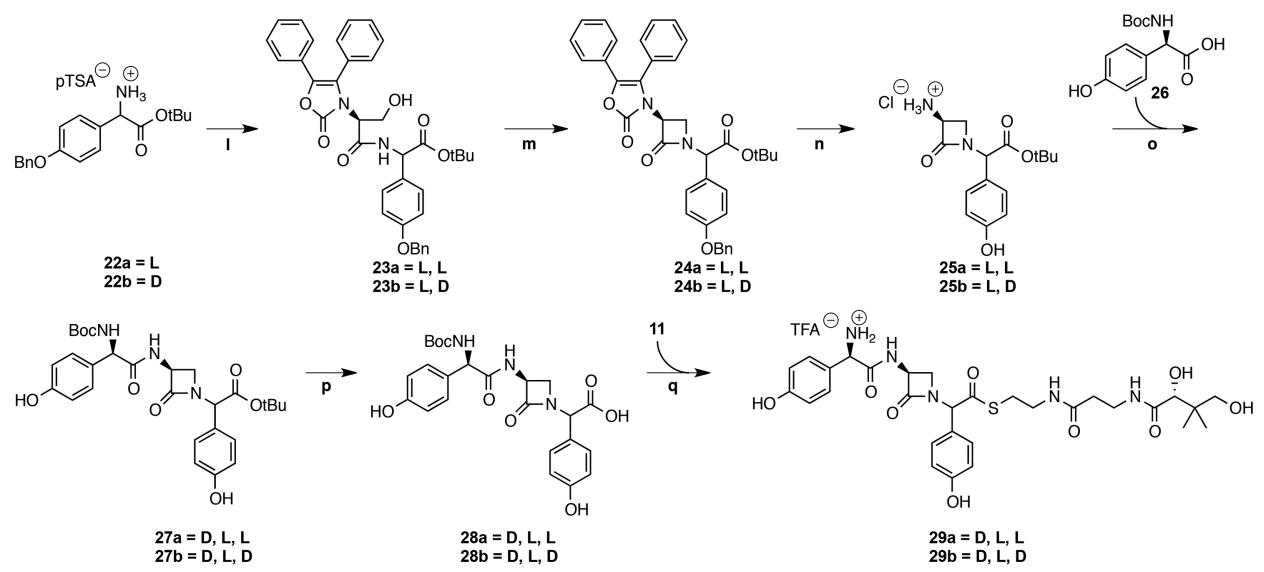

Reaction Conditions: I) Ox-L-Ser, PyBOP, DIEA, DMF, 64\% m) DEAD, P(OEt) $)_{3}$, THF 96\% n) 1. $\mathrm{Pd}-\mathrm{OH} / \mathrm{C}, \mathrm{H}_{2}$ (g) $50 \mathrm{psi}$, THF 2. $\mathrm{HCl}, 92 \%$ over two steps o) 1. 26, 2,6-lutidine, isobutyl

chloroformate, cat. $N$-methylmorpholine, acetone 2. 3-ANA (25a or 25b), 2,6-lutidine, DMF, $67 \%$ over two steps p) 1. TFA 2. $\mathrm{Boc}_{2} \mathrm{O}, \mathrm{DIEA}, \mathrm{THF} / \mathrm{H}_{2} \mathrm{O} 73 \%$ over two steps q) 1. 11, PyBOP, $\mathrm{K}_{2} \mathrm{CO}_{3}$ 2. TFA $41 \%$ over two steps.

Scheme 4.

Synthesis of $\beta$-Lactam Containing Tripeptide Thioesters 


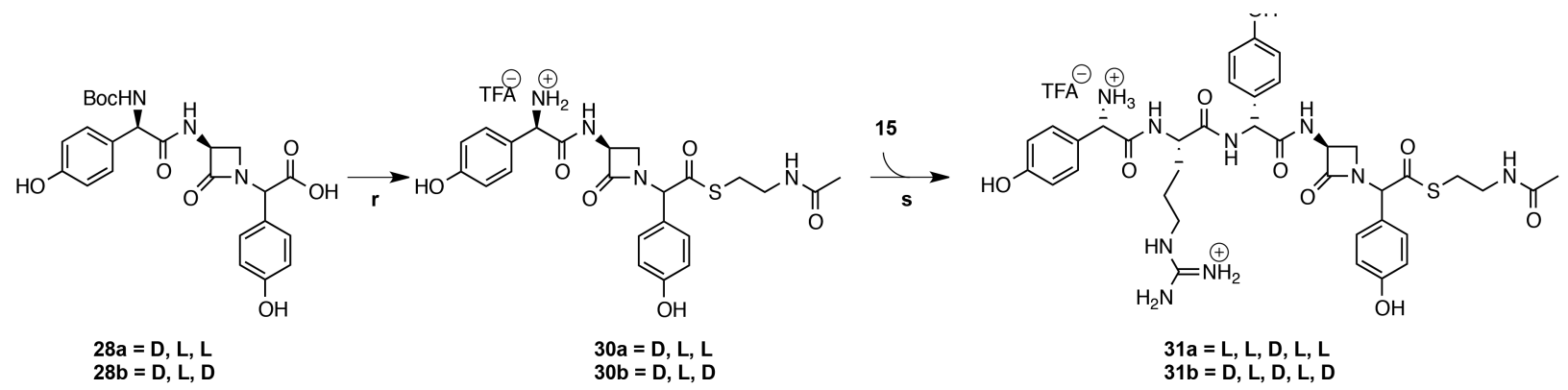

Reaction Conditions: r) 1. SNAC, PyBOP, DIEA 2. TFA 52\% over two steps s) 1 . PyBOP, $\mathrm{K}_{2} \mathrm{CO}_{3}$, free acid from hydrogenation of 152 . TFA $10 \%$ over two steps.

Scheme 5.

Synthesis of $\beta$-Lactam Containing Pentapeptide Thioesters 